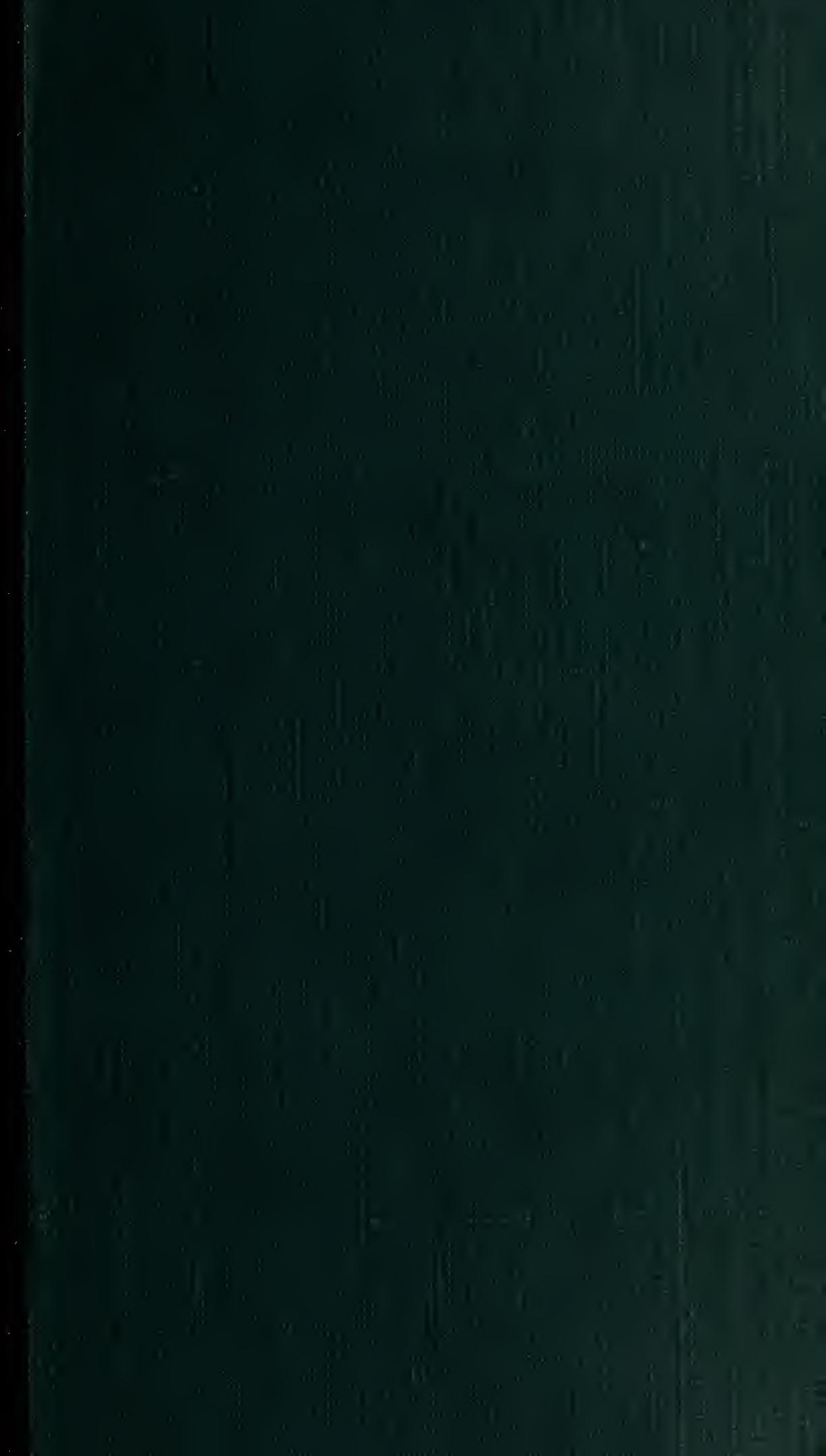




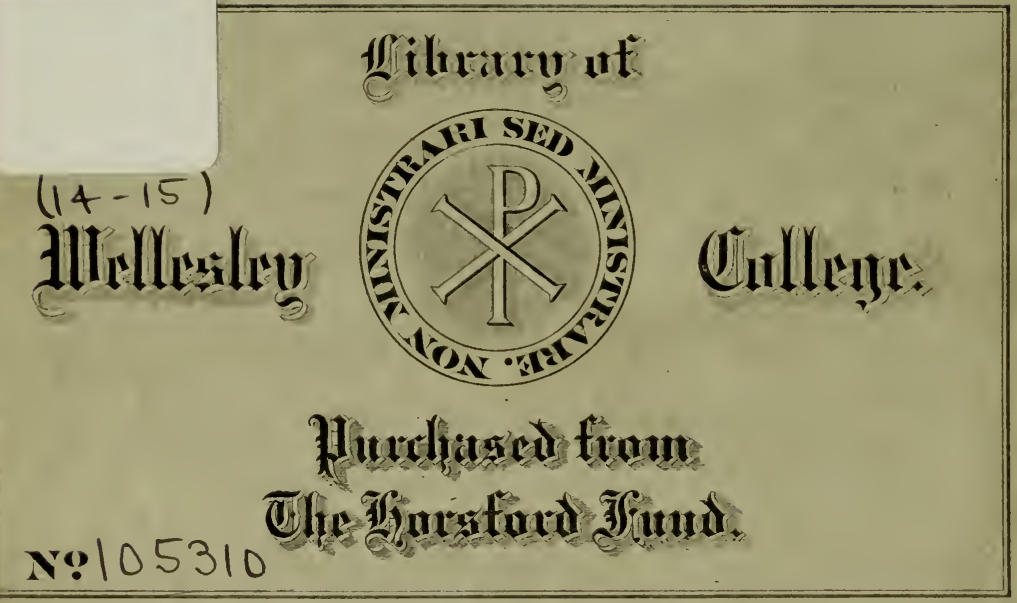




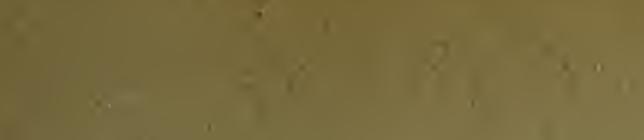

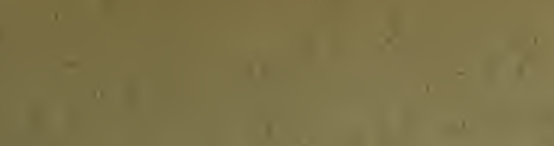

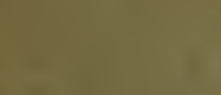

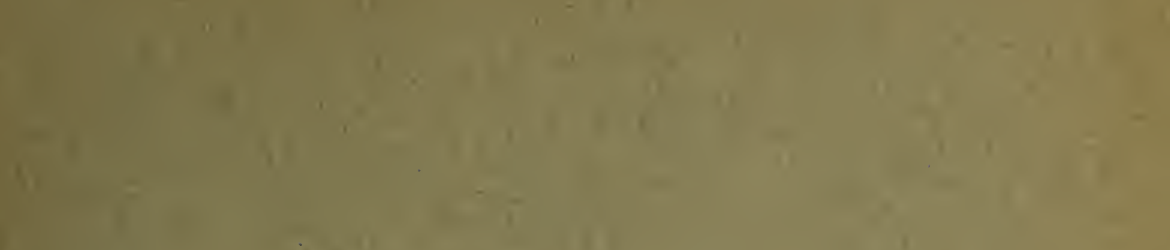

$$
\begin{aligned}
& +1= \\
& 3 . \\
& i=1+n
\end{aligned}
$$

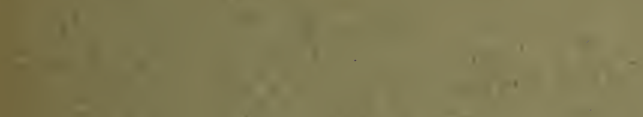

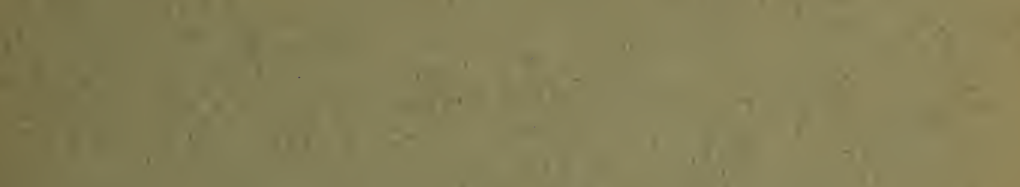

$$
\begin{aligned}
& \text { i }
\end{aligned}
$$

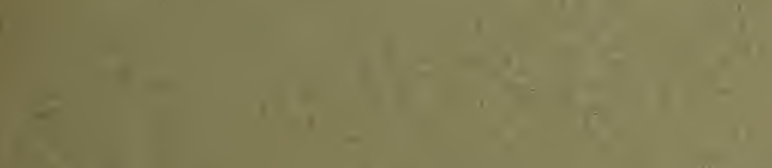

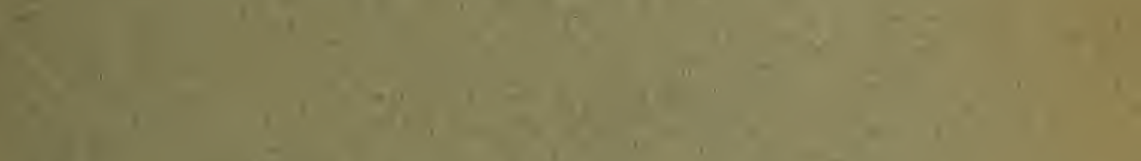

$$
\begin{aligned}
& -1
\end{aligned}
$$

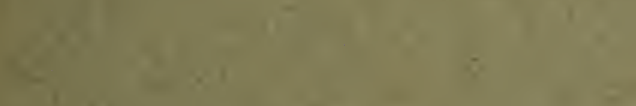

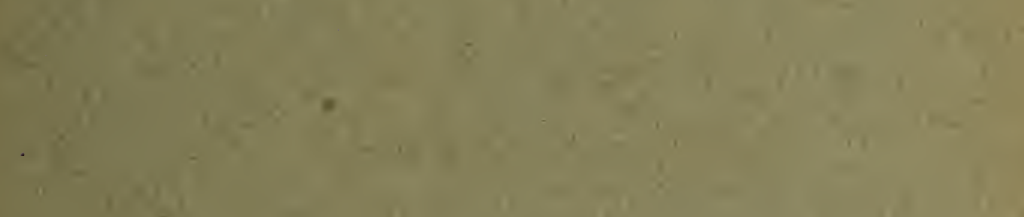

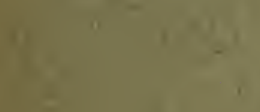

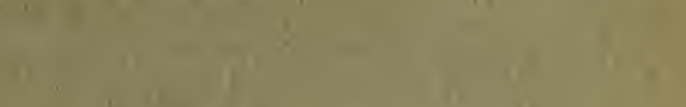

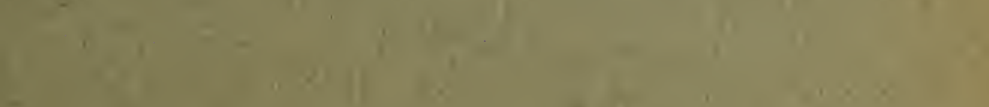

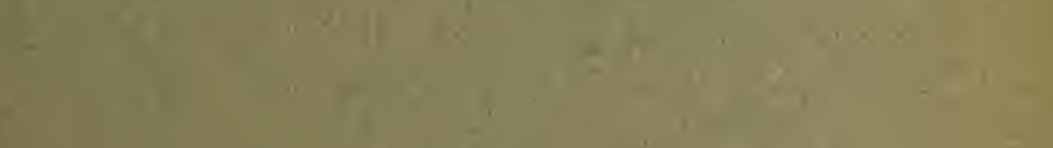

$$
\begin{aligned}
& \text { In }
\end{aligned}
$$

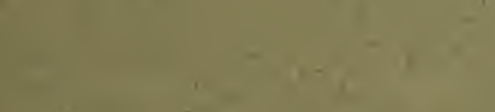

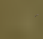

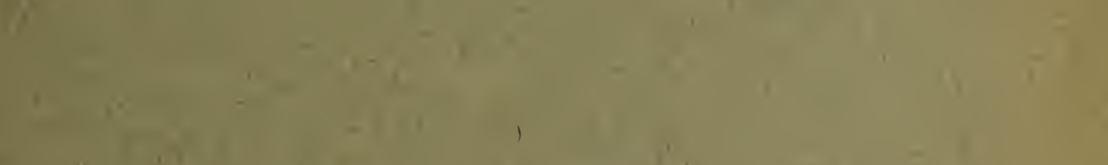

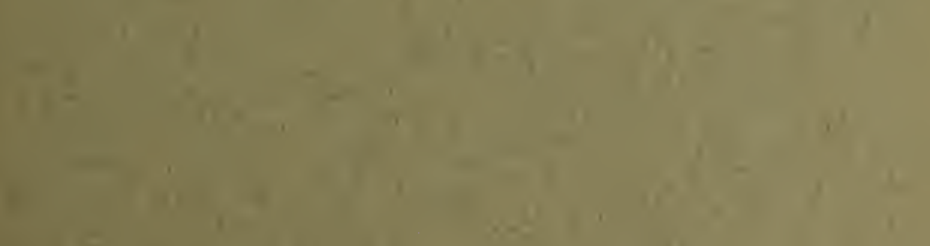

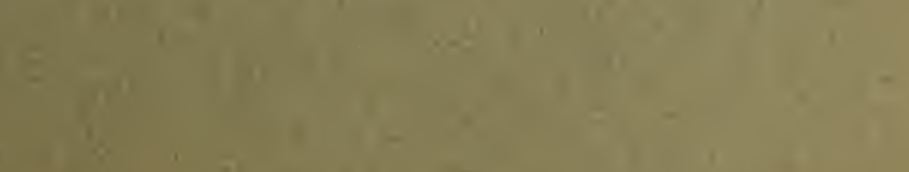

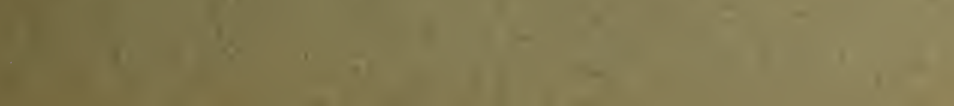





\section{A monograph of the genera Chaetomium and Ascotricha*}

\section{A. H. Chivers}

(WITH PLATES 6-I7)

\section{INTRODUCTION}

In 1902 the writer attempted to arrange and classify a considerable number of specimens of Chaetomium which were then in his herbarium at Hanover, New Hampshire, and which were collected by him in various localities in New England. At that time the only available monograph was the well-known work of Zopf (II3) which contained descriptions of ten species only. While it was possible to identify certain forms in the collection, others were laid aside until more information could be obtained. The study of these first collections, however, aroused so much interest that the writer was led to continue his work on these fungi, and since that time he has been engaged in the preparation of an illustrated monograph of the genus.

It became evident from further examination of the literature that no adequate work on the genus was available, and that from a systematic standpoint it had become greatly confused owing to the multiplication of species which are either synonyms, in many cases even of species not belonging to this genus, or are described without recognizable figures or full and comparative descriptions.

Some time after, when this work was well under way, a monograph of the genus by Bainier (3) appeared, in which twentytwo species and three varieties were described and illustrated, some of which proved to be American, while twelve species and two varieties were described as new. This monograph, although in some respects more comprehensive, was nevertheless like that of Zopf by no means complete. No mention was made of work by American authors or with two exceptions of English literature on the subject, while the repeated use for new species of names already preoccupied introduced a further element of confusion.

* Contributions from the Cryptogamic Laboratory of Harvard University. No. LXXVI, Memoirs of the Torrey Botanical Club, Volume I4, No. 3. [Issued June I0, I9I5.] 
Up to the present time there has been no further attempt to make a comprehensive review of the genus or to collate the American forms, with the exception of the revision of the Chaetomiaceae by Miss Palliser in the North American Flora, where seventeen species are enumerated including three unpublished names.

The writer feels therefore that a thorough and complete study of the subject is much to be desired, and while he cannot hope that the following revision can be final, he has spared no pains to ascertain the facts in every case so far as has been possible, and to make clear by figures and descriptions the specific characteristics of the individual species which in his opinion should be recognized.

The postponement of the final publication for a considerable time on account of unavoidable interruptions and delay caúsed by the preparation of plates seems in the end an advantage, for in the course of his work upon these widely distributed fungi, the writer has been able to examine a very large series of specimens from various herbaria and exsiccati, and to cultivate many species from diverse sources on various media, over long periods of time and through many successive generations. As a result of this examination, numerous forms have been added to those previously recorded from America, and a number of new species have been recognized. In this connection it may be mentioned that all of these forms, with six exceptions, have been extensively cultivated in a pure condition and that it has been possible to determine with accuracy their range of variation as well as their salient specific characteristics.

Those who have given attention to species of Chaetomium must be aware of the more or less unsatisfactory results to be obtained by working with dry herbarium material. Unless the specimens are carefully protected by pill boxes or other convenient receptacles, the characteristic appendages of the perithecia soon become broken, and the thin, brittle, perithecial walls disintegrate. It is the exception to find herbarium and exsiccati material thus protected. On the contrary it is most often mounted on the page with no protection whatsoever, or enclosed in paper envelopes which soon collapse and press against the plants, and it is for 
these reasons that specimens are so of ten broken and damaged. In many cases, therefore, it is unfortunate that new species names have been freely applied to such forms as have seemed to differ from those already named, before it was determined with certainty that such differences as existed were characteristic of the living plant and not peculiar to the dry specimen. Moreover, since all species of Chaetomium which have come to the attention of the writer lend themselves to easy culture on various media, it would seem highly desirable that they should be carefully studied in all stages of development in order that their true characteristics may be determined.

As a result of a thorough review of the literature one hundred and fourteen species names and fourteen variety names have been found which have been applied to forms supposedly Chaetomia. In the present revision a considerable number of changes have been made. Names which were first used in connection with good species have been retained, while many others have been listed as synonyms thereto. For reasons given elsewhere, a considerable number have been excluded, and the writer feels that the use of such names should be discontinued. Certain new names representing new forms heretofore unrecognized have been added to the list of known species. Nevertheless according to the best judgment of the writer, the genus should include not more than twenty-eight species.

A careful study of the genus Bommerella has led to its inclusion under Chaetomium, while on the other hand Ch. chartarum (Berk.) Winter and Ch. pusillum E. \& E., which possess similar characteristics, yet are markedly different from those of the typical species of Chaetomium, have been included in a separate genus to which the name Ascotricha, first given by Berkeley to the plants which Winter later renamed $C h$. chartarum, has been applied.

In connection with his work the writer has been especially fortunate in being able to examine exsiccati in several herbaria and to study a large number of type specimens which have been generously contributed by many individuals both in this country and abroad. Sets of specimens as complete as possible and containing as many of the writer's forms as are available have been distributed to the Royal Botanic Gardens at Kew, the 
Cryptogamic Herbarium at Berlin, the University of Padua, the New York Botanical Garden, and to the Cryptogamic Herbarium at Harvard University. Cultures of several species have been sent to the Centralstelle für Pilzkulturen at Amsterdam.

At this point the writer wishes to acknowledge his indebtedness to those who have aided substantially in the completion of this work; to Dr. Roland Thaxter, especially, who has at all times been ready to encourage and give freely of his time and material, and whose helpful suggestions and guidance have made this work possible; to Professor W. G. Farlow for the use of his herbarium and literature from his private library; to Professor G. F. Atkinson, Dr. J. H. Faull, Dr. L. W. Riddle, Dr. I. F. Lewis, Dr. A. F. Blakeslee, Dr. George R. Lyman, Mr. R. H. Colley, and Mr. A. T. Speare, for material for cultures; to Dr. P. A. Saccardo, Mr. George Massee, Dr. G. Lindau, Dr. Charles H. Peck, Dr. J. Dearness, Dr. P. Hariot, Dr. F. Cavara, Dr. C. H. Kauffman, Dr. L. H. Pammel, and Dr. Elam Bartholomew, for valuable type material and authentic specimens; to Mr. A. B. Seymour and to Mr. Piguet for assistance in reference work.

This investigation was begun in the Cryptogamic laboratories of Harvard University under the guidance of Dr. Roland Thaxter, and completed in the botanical laboratories of Dartmouth College.

\section{The Genus Chaetomium, Historical Review}

The contributions of a systematic nature which have been made to the genus Chaetomium are numerous and cover a considerable period dating back to I8I7. In the brief summary which follows it will be possible to discuss only those which are most important and to call attention in a very general way to a host of minor contributions which have been made by writers little acquainted with the characteristics of the forms in this genus.

In I8I7 Gottfried Kunze (50) published a description of a hitherto unrecognized genus and gave to it the name Chaetomium ( $\chi \alpha i \tau \omega \mu \alpha$, a hair). It is of interest to note his characterization of the genus, since he clearly discerned some features which many later writers have disregarded, while on the other hand, he made errors in describing structures which later writers have 
corrected. According to his description the perithecia were globose, membranaceous, clothed on all sides with opaque hairs, and at length became pierced by an opening at the summit. The spores were pellucid and mingled in a gelatinous mass. The fungus appeared like an inverted Myrothecium of Tode. The spherical or steeple-shaped fruiting body consisted of a cuticular integument, trimmed with long, mostly stiff opaque hairs enveloping a more or less globular, gelatinous mass in which spores were mixed. Under the influence of moisture the semi-transparent enclosing walls opened by a central pore and drew back more or less. The wall closed as it became dry and reopened with returning moisture. This happened as long as the perithecium contained spores.

It may be seen from the above description that Kunze saw clearly an important fact, namely that the perithecium possessed a pore through which the spores were discharged, but that on the other hand he failed to interpret aright its internal structure. It is not difficult for one acquainted with the appearance of the structure within the perithecial wall to understand how, with comparatively slight magnification, he mistook these structures for a mass of jelly and failed to discover the asci of which the mass is made up. Hence the fact that asci were present in these plants was entirely overlooked.

Ch. globosum Kze. (50) was named and described as characteristic and typical of the genus. According to his own statement Kunze was familiar with several other species of Chaetomium, and it was his intention to publish a monograph at a later date, but with the exception of a description of an interesting species under the name Ch. elatum Kze. (5I) this author published nothing further on Chaetomium.

In spite of the fact that not less than thirteen new species were described by Ehrenberg (28), Fries (38), Wallroth (109), and Schweinitz (9I) during the years immediately following Kunze's work, no contribution of value was made until 1837 . Writers up to this time had not discovered the presence of asci nor had they considered the size of spore's an aid to the identification of species. In many diagnoses of new forms the fact that the genus had been characterized by Kunze as possessing an ostiole seems to have been entirely overlooked. 
With the publication of his Icones by Corda $(21,22,23)$ in 1837 , I 838 and I 840 came quite a new era in the history of the genus. This author amended the original description given by Kunze as follows: "Peridium membranaceous, at length opening at the apex by a pore, clothed on the outside with opaque hairs, supported by a more or less well-developed, fibrous hypothallus: spores grouped together, ascomorphic, pedicellate, at length discharged as simple powdery spores. Pedicels without mucous." It may be readily seen that from the amended description one is able to form a much more accurate judgment of the characteristics of the genus.

Corda was the first to study the internal structure which other authors had been content to call a gelatinous mass. He observed this to be made up of bodies which he called asci, though according to his description he was misled in believing that these bodies functioned as pedicels on which the spores were borne. Corda's descriptions are for the most part illustrated by figures which are elaborate for his time, and while it is not possible to determine with certainty all of the forms with which he dealt, several may be easily recognized. Of the seven new species described Ch. indicum and Ch. murorum stand out as those to be retained, while the remaining five have been referred to other genera, treated as synonyms, or excluded.

Between the time of Corda and the appearance of Zopf's monograph in I88I descriptions of at least thirty-two new species appeared. In fact so many contributions were made that it will be possible to mention here only those which furthered the accurate knowledge of the genus. In I 849 Fries (39) called attention to the fact that in Chaetomium the spores are formed in typical asci, though the asci are rarely conspicuous. This is the first recognition of the true character of the perithecial contents which Corda had mistaken for spore-bearing pedicels and which al other writers had described as a gelatinous mass including spores. Fuckel (42) and Cook (16) also made valuable contributions in I 869 and I 873, respectively, in their descriptions of two new species under the names Ch. crispatum and Ch. funicolum.

The well-known monograph of Zopf (II3), to which reference has been made on a preceding page, marked the appearance of a 
work of an entirely different nature from that of many preceding authors, and it is only to be regretted that the monograph could not have been made more complete by its author. Zopf recognized the necessity of making descriptions clear and complete, of including details, and of presenting figures with the descriptions. It will be remembered that in his monograph Zopf divided his species into two subgenera, Chaetomium and Chaetomidium. Under the first subgenus he described as new and figured $C h$. spirale; renamed, described, and figured Kunze's Ch. globosum under the name Ch. Kunzeanum; described and figured $C h$. murorum Cda., Ch. pannosum Wallr., Ch. crispatum Fckl., and Ch. indicum Cda.; described Ch. cuniculorum Fckl., Ch. elatum Kze.; redescribed and figured his own species, Ch. bostrychodes, which had already appeared at an earlier date. Under the subgenus Chaetomidium he described and figured Ch. fimeti Fckl.

Since I88I, writers have for the most part been content with publishing scattered new species and varieties, and no one has attempted a complete survey of all which have appeared, or a revision of the badly confused literature. Among these forms, which number at least forty and which represent the work of nearly as many authors, two only can be regarded with certainty as good species; Ch. contortum, described by Dr. Peck (67) in I 896 and Ch. simile, by Massee and Salmon (59) in I902. During the year I9I0, however, Miss Helen L. Palliser (65) wrote her revision of the Chaetomiaceae of North America, and in the same year Bainier (3) published his monograph of the genus. The work of both these authors includes the study of a considerable number of forms.

In Palliser's revision seventeen species are enumerated, fourteen of which had previously appeared in publications of other authors. Ch. aterrimum is described for the first time under a name given it by Ellis and Everhart, while Ch. cochliodes, Ch. spirochaete, and Ch. flexuosum are described as new. At the end of her paper four species are enumerated as doubtful forms. It may be well to state here the more important differences in arrangement between Palliser's paper and that of the present writer. In Palliser's revision Ch. caninum E. \& E. stands as a 
species, rather than as a synonym of Ch. bostrychodes Zopf; Ch. lanosum Peck and Ch. olivaceum C. \& E. appear as species, rather than as synonyms to Ch. globosum Kze. The name Ch. Ellisianum Sacc. is retained for the plant which the present writer has renamed Ascotricha pusillua (E. \& E.); Ch. contortum Peck is treated as a synonym to $C h$. crispatum Fuckel, rather than as a distinct species; Ch. melioloides C. \& P. is recorded as a species, rather than as a synonym of $C h$. indicum Cda.; Ch. sphaerospermum C. \& E. is treated as a species of the genus Chaetomium rather than as Ascotricha chartarum Berk.; Winter's name, Ch. setosum, is retained and Ch. indicum of Zopf, but not of Corda, appears as a synonym thereto.

The monograph of the genus Chaetomium by Bainier contains a brief historical sketch and review of the work on development; a characterization of the genus; a description (with figures) of twenty-two species and three varieties, twelve species and two varieties of which are described under new names as follows: Ch. megalocarpum, Ch. contortum (not of Peck), Ch. spirilliferum, Ch. undulatum, Ch. setosum (not of Winter or of Ellis \& Everhart), Ch. comosum, Ch. glabrum (not of Berkeley \& Broome), Ch.tortile, Ch.formosum, Ch. formosum, var. ovatum, Ch. formosum, var. neglectum, Ch. caprinum, Ch. torulosum and Ch. rigidulum. The most striking characteristic of Bainier's monograph is the multiplication of species and the fact that several species and varieties have been made from Ch. globosum Kze. and Ch. bostrychodes Zopf, both of which are variable forms. It should here be noted that three of the names used by Bainier, viz., Ch. contortum, Ch. setosum, Ch. glabrum, must, if the priority rule is to be followed, be changed, since Dr. Peck had previously used the name contortum; Winter, and later Ellis and Everhart, had made use of the name setosum, and Berkeley and Broome had used the name glabrum.

\section{Characters of the Genus Chaetomium}

Perithecium superficial, spherical and translucent when young, when mature subglobose or elongated, colored and more or less opaque, pierced at the upper extremity by an ostiole. Perithecium wall membranaceous, brittle, distinctly cellular, provided with appendages in the form of variously modified hairs. Mycelium 
in the form of a densely aggregated mass of fungus threads radiating in ropy strands from the point of origin. Asci thinwalled, delicate, stalked, evanescent, club-shaped or rarely linear and cylindrical, eight-spored. Spores single-celled, colored, most frequently olive-brown, typically lemon-shaped.

\section{Key to the Species of Chaetomium}

I. Terminal hairs unbranched.

A. Terminal hairs straight or nearly so. Spores irregularly triangular.

I. Ch. trigonosporum (p. I66).

B. Terminal hairs flexuous, circinate at their tips.

Terminal hairs slender, about $4 \mu$ in thickness, with open, circinate tips. Plant bluegray to blue-black.

2. Ch. murorum (p. I66).

Terminal hairs stout, about $7 \mu$ in thickness, coarsely encrusted, with closed, circinate tips 2-3 times re-curved. Plant grayblack.

3. Ch. circinatum (p. I68).

C. Terminal hairs tortuous, consisting of successively reversed loops with connecting arches. Tips circinate.

Terminal hairs stout, $15 \mu$ in thickness at crown of terminal arch. Arches short and loops closely approximated. Perithecium large with diameter as great as 1050 $\mu$.

Terminal hairs slender. about $6 \mu$ in thickness at crown of terminal arch. Arches long and graceful, loops far apart. Perithecium not exceeding $340 \mu$ in diameter.

Terminal hairs rather slender, about $7.5 \mu$ in thickness at crown of terminal arch. Arches short and loops closely approximated. Perithecium not exceeding $350 \mu$ in diameter.

D. Terminal hairs tortuous or spirally coiled.

Terminal hairs contorted as well as intricately and irregularly spirally coiled, usually with arched circinate tips. Perithecia subglobose. Plant gray-black.

Terminal hairs coiled above into a spiral of constantly decreasing diameter, the lower coils of which are large and distant, the upper ones, smaller, closely approximated. Tips not circinate. Perithecium subglobose. Plant blue-gray.

4. Ch. contortum (p. I69).

5. Ch. simile (p. I69).

6. Ch. crispatum (p. I7I).

7. Ch. tortile (p. I72).

8. Ch. conrolutum (p. I73). 
Terminal hairs more slender, finely coiled above into a spiral of small diameter which soon becomes frayed, taking on the character of a woolly thread. Perithecium elongated, barrel-shaped. Plant gray.

9. Ch. subspirale (p. I73).

$E$. Terminal hairs more or less evenly and continuously arcuate from base to incurved tip.

Terminal hairs incurved at tips, spores irregularly ovate. Plant gray, pale olive or golden yellow.

Terminal hairs circinate or slightly convolute at tips. Spores fusiform. Plant gray to pale olive.

Terminal hairs $I-3$ spirally convolute at tips. Spores with shape of a section of an orange. Plant olive yellow.

II. Terminal hairs constantly and conspicuously branched, straight or nearly so, at least not regularly undulate or spirally coiled.

A. Terminal hairs dichotomously branched.

Terminal hairs branching by acute angles, about $6.5 \mu$ in thickness at base. Perithecium small, not exceeding $160 \mu$ in diameter. Plant blàck at maturity, graygreen in old age.

Terminal hairs of two types; (a) stout, branching by obtuse angles with branchlets reflexed; $(b)$ more slender, irregularly constricted and inflated, branching by narrow, acute angles. Perithecium not exceeding $200 \mu$. Plants black.

Hairs large, coarsely roughened, branched by obtuse or acute angles. Perithecium large with diameter as great as $500 \mu$. Plant greenish when young, black at maturity.

B. Terminal hairs never dichotomously branched.

Terminal hairs in form of stiff, spine-like shafts. Perithecia subglobose. Spores egg-shaped. Plant golden yellow.

Terminal hairs much longer, collapsed and flexuous above. Perithecium extremely elongated. Plant ochraceous.

III. Terminal hairs branched, with branches anastomosed forming a network.

13. Ch. funicolum (p. I76).

14. Ch. indicum (p. I78).

I5. Ch. elatum (p. I80).

I6. Ch. spinosum (p. 187).

I 7. Ch. ampullare (p. 187 ).

I8. Ch. cuniculorum (p. I88).

IV. Terminal hairs branched but not regularly or conspicuously so, undulate or spirally coiled. 
A. Terminal hairs undulate or loosely, spirally coiled.

Terminal hairs undulate, extremely fine and delicate, yellow, frequently branching several times. Perithecium globose below, narrow above. Plant gray or olive yellow, at maturity golden yellow.

Terminal hairs undulate or loosely spirally coiled. Branches few. Plant gray, olivegreen or chocolate-brown.

B. Terminal hairs convolute in definite spirals.

a. Perithecia gray when young, becoming black in old age.

$x$. Perithecia subglobose or ovate.

Terminal hairs slender, about $5 \mu$ in thickness near their tips, with 6-I4 coils. Spores large, $9 \times 7 \mu$, rich olive-yellow to olive-brown.

Terminal hairs stout, about $9 \mu$ in thickness near tips with I0-18 coils. Spores olive-brown, $7 \times 6 \mu$.

Terminal hairs regularly coiled with 5-7 convolutions, or irregularly coiled with 2-3 loose convolutions, frequently producing branches. Spores elliptical in face view, hyaline or only slightly colored, 7.4-6 $\mu$.

y. Perithecia elongated.

Spores in face view four-sided and four-angled.

Spores lemon-shaped or globose.

$b$. Perithecia green or golden yellow.

$x$. Perithecia subglobose or ovate.

Terminal hairs of two types; (a) stout, straight below, with three or four convolutions near tip; (b) slender, delicate, either coiling in spirals or twisting irregularly. Plant olive-green.

Terminal hairs of three types; $(a)$ long, straight, tapering; (b) slender, straight below, coiling above spirally with about 5-7 convolutions; (c) stout, coarse, straight below, spirally coiled above with about $2-3$ convolutions, frequently branched. Plant olive-green.

$y$. Perithecia elongated, bottle-shaped.
I9. Ch. sphaerale (p. I89).

20. Ch. globosum (p. 190).

2I. Ch. spirale (p. 199).

22. Ch. aterrimum (p. 200).

23. Ch. bostrychodes (p. 20I).

24. Ch. quadrangulatum (p. 202).

25. Ch. caprinum (p. 203).

26. Ch. cochliodes (p. 204).

27. Ch. angustum (p. 206). 
Terminal hairs constricted at the septa, straight below, collapsed, irregularly undulate and branched above. Plant golden-yellow.

28. Ch. torulosum (p. 207).

I. Chaetomium trigonosporum (Marchal) comb. nov. Bommerella trigonospora Marchal, Bull. Sọc. Roy. Bot. Belgique 24: I. I885; 28:26I-27I. pl. IO. I 889.

\section{Plate 6, Figs. 6-I I}

Black. Perithecia of medium size, globose or subglobose to somewhat elongated, $315 \times 22 \mathrm{I} \mu(250-340 \times \mathrm{I} 60-262)$, provided with long, slender, straight or curved, black cirrhi, seated on a mat of hyphae which are olive-yellow to olive-brown. Lateral hairs rather numerous, comparatively short, spine-like, tapering, below dark olive-brown, minutely roughened, conspicuously and evenly septate, at base about $4.7 \mu$ in thickness; above faded, pale yellow, obscurely septate, smooth, near tip colorless. Terminal hairs straight, unbranched, longer than the lateral ones, dark rich olive, regularly septate to near the tips, smooth or only slightly and obscurely roughened, at base about $4.7 \mu$ in thickness, at tip pale yellow or colorless, without septa. Asci narrowly and irregularly club-shaped, 8 -spored, $50 \times 8 \mu$, pars sporif. $32 \mu$. Spores when young greenish and filled with highly refractive globules, when mature rich olive-yellow to dark olive-brown, in face view irregularly triangular, $8.9 \times 5.7 \mu(8.1-9.7 \times 4.8-6.4)$, when seen edgewise nearly oval, 3.6-4 $\mu$ broad.

On rabbit dung, North Carolina, Herb. R. Thaxter (Chivers No. 6). Type locality: in heath near Aerschot, Belgium; on dung of hare.

So far as the writer is aware this is the only form with straight, unbranched, terminal hairs to be included in this genus. The species has been grown in varied cultures for many years and seems to be a true Chaetomium both in its life history and specific characteristics. While the spores which are here roughly triangular differ in shape from those of the greater number of species, the variation is no greater than in those of Ch. quadrangulatum where they are four-sided and four-angled.

2. Chantomium murorum Corda, Icones i: $24 . p l .7, f .293 B$. I 8.37 ; Icones $2: 29$. pl. I3, f. IO3. I 838

Chaetomium comatum, var. helicotrichum Saccardo, Michelia I: 222. $\mathrm{I} 878$. 
Chaetomium griseum Cooke, Grevillea I: I75. I873.

\section{Plate 8, Figs. 6-Io}

Blue-black. Perithecia of medium size, globose or ovate with a bluntly pointed base, $278 \times 267 \mu(243-337 \times 206-337)$. Lateral hairs long, graceful, flexed, insensibly tapering to a point, delicate when young, when mature about $7.5 \mu$ in thickness, dark olive-brown near base, gradually fading at tip, conspicuously granular-roughened, or nearly smooth, clearly or obscurely septate. Terminal hairs variable with age; when young stout, about $5.5 \mu$ in thickness at the middle of their length, not circinately curved at tips, but broadly arched throughout their length; at maturity slender, about $4 \mu$ in thickness, gracefully flexed or nearly straight, ending in a graceful arch with circinate tip, dark rich olive-brown, sparsely and irregularly septate, smooth or roughened by irregular projections, in old age becoming still darker, frequently losing their circinate tips and tending to become wavy throughout. Asci broadly and irregularly clubshaped, 8 -spored, $53 \times$ I9 $\mu$, pars sporif. $34 \mu$. Spores filled with greenish refractive globules when young, when mature dark olive-brown, globose-ovate to narrow elliptical, apiculate at both ends or apiculate at one end and umbonate at the other, frequently collapsing by a longitudinal furrow, I $2.6 \times 8$.I $\mu$ (I I.3-I2.9 $\times$ 8.I), when seen edgewise, compressed, $6.4 \mu$ broad.

Exsiccati.-Fung. Europ., Series II, Edit. nova, III, 234. Sub Ch. Kunzeanum Zopf: Fung. Gall. XLV, 4436.

This species is extremely common, growing on dung of various animals, especially on dog dung, and on very varied substrata from all parts of New England (Chivers No. I3). Reported also from Montana, by Ellis and Everhart (Anderson No. 65I); from England, by Massee and Salmon; and from Germany, by Zopf. Type locality: Prague; on damp walls.

It may be seen from the above that Ch. griseum described by Cooke in I 873 and Ch. comatum, var. helicotrichum by Saccardo in 1878 are considered as synonyms of Corda's species. A careful study of the former has been made from type material received from the Royal Botanic Gardens at Kew and the characteristics noted seem to agree in every way with those of $\mathrm{Ch}$. murorum, though Cooke stated that the threads of his species were stouter and the spores larger and colorless. Through the kindness of Dr. Saccardo it has also been possible to examine 
type specimens of his variety and while he found a similarity to Ch. murorum only in the circinate tips of the hairs, the present writer has found all the characteristics of the plants examined to be typical of Corda's species. On the contrary there seem to be no reasons for considering the form related in any way to $C h$. comatum, since the hairs are not branched.

Only Ch. elatum Kze. could be obtained from exsiccati specimens in Rabenhorst's Fungi Europaei No. 234.

Ch. murorum Cda. may at first sight be confused with $\mathrm{Ch}$. circinatum, but may easily be distinguished from it by the smaller diameter of the terminal hairs which are only $5.5 \mu$ in thickness, and which are flexed not sinuous, slightly if at all recurved at their tips, and more minutely and inconspicuously roughened.

\section{Chaetomium circinatum sp. nov.}

Plate 8, Figs. I -5

Gray-black. Perithecia of medium size, ovate or globose, $325 \times 312 \mu\left(270-344 \times 25^{8-335)}\right.$. Lateral hairs long, flexed, graceful, sparsely and irregularly septate, at base olive-brown, roughened, $5.6 \mu$ in thickness, at the apex smooth, pale olive, slender. Terminal hairs dark, nearly opaque, olive-brown or brownish-black, sinuous, $7 \mu$ in thickness, at the base irregularly encrusted, at the apex smooth or only slightly encrusted, circinate, two to three times re-curved. Asci irregularly club-shaped, 8 -spored, $70 \times 25 \mu$, pars sporif. $50 \mu$. Spores ovate or lemonshaped, apiculate or umbonate, olive-brown, I4.3 $\times 8.9 \mu$ (I2.9I $5.3 \times 8.1-9.7$ ).

A rare species having appeared only once on a piece of old burlap in a refuse heap, Worcester, Massachusetts (Chivers No. 12).

This species, while similar in certain respects to Ch. murorum, may be easily distinguished from it by the characteristic terminal hairs which are sinuous instead of flexed, roughened by crystals of calcium oxalate, which are irregularly clustered along their entire length, circinately recurved at the tips, the last coil of which often springs out to one side or the other from the plane of coiling. 
4. Chaetomium contortum Peck, Rep. New York State Mus. Nat. Hist. 49: 24. I896

Plate 9, Figs. IO-I2

Black. Perithecia large, globose or subglobose, $875 \times$ I050 $\mu$. Lateral hairs numerous, straight or flexed, clearly septate, smooth, some with equal diameter and olive-yellow throughout, others thicker (about $5.6 \mu$ ) and dark olive-brown at base, gradually tapering and fading toward tip. Terminal hairs dense olivebrown to black, without visible cross walls, roughened throughout with blunt, flat-topped projections, nearly straight below, contorted above into loops which are separated by short, abrupt arches, terminating in an arch with circinate, recurved tip, I5 $\mu$ in thickness at the crown of the terminal arch. Asci "fugacious." Spores when young hyaline, refractive, filled with refractive globules, when mature dark rich olive-brown, irregularly lemonshaped, not always symmetrical, sometimes apiculate at ends, sometimes barely angular, I I.6 $\times 9.4 \mu$ (I0.5-12.5 $\times 7.5^{-10.5)}$.

So far as the writer is aware this species has never been found except in the type locality: Woodside, New York; on bulbs of lilies, Lilium longiflorum (F. C. Stewart).

On account of the fact that only two mounts of the type material received from Dr. Peck have been available, it has been impossible to determine the characteristics of the asci, for although the perithecium in one mount was broken and the young asci were exposed, they could not be accurately studied. It has seemed desirable, therefore, to quote from the original description regarding the asci.

This species has certain features in common with $C h$. crispatum, Ch. simile, and Ch. tortile. From the first it differs in the greater dimensions of the perithecium, and the greater width and more regular looping of the terminal hairs. From $\mathrm{Ch}$. simile it differs in the greater dimensions of the perithecium, the greater width and more compact looping of the terminal hairs and the greater size of its spores. From Ch. tortile it differs in the greater dimensions of the perithecium, in the greater width and more regular looping of its terminal hairs and the greater size of its spores.

5. Chaetomium simile Massee \& Salmon, Ann. Bot. i6: 7 I.

$$
\text { pl. 4, f. 8, g. } 1902
$$

Chaetomium glabrum Bainier, Bull. Soc. Myc. France 25: 2 I4. pl. $2 I, f . I-4 . \quad$ I9IO. 


\section{Plate 9, Figs. I-4}

Dark gray to black. Perithecia of medium size, globose or subglobose, frequently of greater diameter horizontally, 23I$295 \times 23 \mathrm{I}-337 \mu$. Lateral hairs not differentiated, but appearing about the perithecium as a tomentum of yellow, semi-transparent, fine and delicate mycelial threads. Terminal hairs dense olive-brown to black, with low power smooth, but with immersion lens irregularly thickened with extremely minute spines, irregularly and sparsely septate, nearly straight below, contorted above into loops which are separated by long, graceful arches, terminating in an arch with circinate tip, 5.6-7 $\mu$ in thickness at the crown of the terminal arch. "Asci cylindrical, about $80 \times 9$-I0 $\mu$, 8-spored." Spores monostichous, when young hyaline, filled with refractive greenish globules, when mature dark rich olive-brown, subglobose or very broadly elliptical, some clearly apiculate at one end, barely so at the other, others apiculate only at one end and rounded at the other, Io $\times 8 \mu$ (9.5-10.5 $\times 7.5-8.9$ ), when seen edgewise, compressed, $6.4 \mu$ broad.

Type locality: Kew, England; on dog dung.

Although it has been impossible to examine type material of the plant which Bainier found on dog dung and described under the name Ch. glabrum, in I9Io, the writer is convinced that it is identical with Ch. simile. The measurements of the perithecia and spores are the same for both species and the development of the dark area near the top of the perithecium which Bainier noted as unusual appears in all species of Chaetomium where the wall remains so transparent that the darkened spore mass may be seen.

Through the kindness of the Royal Gardens at Kew the writer has been enabled to study type specimens of $C h$. simile, but as no asci could be found in mounts made from this material, the original description has been quoted and the figure of the ascus has been copied.

At first sight one may confuse this species with $C h$. contortum, Ch. crispatum and Ch. tortile. It differs from these, however, in the terminal hairs which are of much smaller diameter and which form long, graceful arches between their loops. It differs also from $C h$. contortum in the smaller size of the perithecium and from both $\mathrm{Ch}$. contortum and Ch. crispatum in its slightly smaller spores. 
6. Chaetomium Crispatum Fuckel, Symb. Myc. 90. 1869 Sphaeria crispata Fuckel, Fung. Rhen. 2022. I 867.

Chaetomium streptothrix Quélet, Mém. Soc. d'Emul. Montbeliard 1875: 103. pl. 4, f. 40. I876.

\section{Plate 9, Figs. 5-9}

Gray to gray black. Perithecia of medium size, globose or subglobose with a bluntly pointed base. $263 \times 253 \mu$ (I98-320 $\times$ I83-350). Lateral hairs numerous, straight or slightly flexed, long, slender, gradually tapering to a point, smooth, regularly septate, about $4 \mu$ in thickness and dark olive-brown at base, fading to yellow and becoming colorless near the tip, frequently breaking at maturity and giving to the surface of the perithecium a coarse, rough appearance. Terminal hairs dense olive-brown to black, rather evenly roughened with minute spines throughout, below about $4 \mu$ in thickness, straight or slightly curved, septate, twisting or coiling above into an irregular spiral, near the tip forming alternate loops and arches, ending in an arch with circinate tip, irregularly and obscurely septate above, enlarging to $7.5 \mu$ in thickness at the crown of the terminal arch. Asci 8spored, long, narrow, cylindrical, 80-Ioo $\times 8-\mathrm{IO} \mu$, pars sporif. $65-80 \mu$. Spores monostichous, hyaline and filled with greenish refractive globules when young, when mature, dark rich olivebrown, lemon-shaped, apiculate at both ends or broad and apiculate at one end and slightly more pointed and less conspicuously apiculate at the other, II.7 $\times 8.8 \mu$ (II.3-I2.I $\times 8$. I-9.7), when seen edgewise, compressed, lenticular, $6.4 \mu$ broad.

This species has been found frequently on various substrata from different localities in New England (Chivers No. 9). Reported also from England, and various localities in Europe. Type locality: in the cellar of L. Fuckel; on rotting potatoes.

Exsiccati.-Fung. Sax. XXIV, II67. Sub Sphaeria crispata Fuckel: Fung. Rhen. 2022.

In I 876 Quélet described under the name $C h$. streptothrix fungi which he found on rotting potatoes and which he thought might be the ascosporic stage of Peronospora infestans. While there ara no figures accompanying his brief and somewhat indefinite description, it seems probable that it is identical with Fuckel's species for the following reasons: the hairs are described as tortuous, the specimens were found on rotting potatoes, a place where one is peculiarly likely to find $C h$. crispatum, and the name which he gave indicates the same type of twisted hairs. 
Ch. crispatum differs in its peculiarly contorted terminal hairs from all other species which the writer has studied, with the exception of $\mathrm{Ch}$. contortum, $\mathrm{Ch}$. simile and $\mathrm{Ch}$. tortile. It has a smaller perithecium and terminal hairs of much smaller diameter and with more irregular coilings than in Ch. contortum; terminal hairs of slightly greater diameter and with much more irregular coilings, and spores of greater diameter than in Ch. simile; a smaller perithecium, more regularly contorted hairs and larger spores, than in Ch. tortile.

The writer has seen specimens of the exsiccati mentioned above and has made and examined mounts from them.

7. Chaetomium tortile Bainier, Bull. Soc. Myc. France 25: 2 I4. pl. 22. 1910

\section{Plate 9, Figs. I3-I7}

Gray black. Perithecia of medium size, globose or subglobose with a bluntly pointed base, 3I $2 \times 290 \mu(228-350 \times 228-319)$. Lateral hairs numerous, $3.8 \mu$ in thickness, dark olive-brown at base, fading to hyaline at the tips, septate, smooth throughout, often breaking at maturity leaving their bases which give to the perithecium wall a coarse, rough appearance. Terminal hairs dark olive-brown to black, roughened with minute spines, irregularly and sparsely septate, about $5.6 \mu$ in thickness at the middle of their length, nearly straight or flexed below, intricately contorted above, at times coiling into a regular spiral, then twisting in the opposite direction forming a series of congested coils which may be thrown out of line with the main axis, terminating in an irregular or regular spiral, or in a loop followed by an arch with circinate tips. Asci long, cylindrical, 8-spored, I00 $\times 8$-Iо $\mu$, pars sporif. 50-60 $\mu$. Spores monostichous, hyaline when young, when mature dark, rich olive-brown, subglobose or very broadly elliptical, varying from clearly apiculate to obscurely angular, $8 \times 6.5 \mu\left(7.5^{-9} \times 6-6.8\right)$.

On rabbit dung, Hanover, New Hampshire (Chivers No. II). Type locality: Bainier makes no mention of the place where he found this species or the substratum on which it grew.

Ch. tortile is in certain respects similar to Ch. contortum, Ch. crispatum, and Ch. simile. The terminal hairs are much more complicated in their twistings than in those of the other species mentioned and more slender than those of $C h$. contortum. The spores are smaller than those of Ch. contortum or Ch. crispatum. 
8. Chaetomium convolutum Chivers, Proc. Am. Acad. 48: 85 . I9I 2

Plate I4, Figs. 9-12

Blue-gray. Perithecia of medium size, globose or subglobose, $244 \times 232 \mu \quad(236-254 \times 224-240)$, frequently provided with cirrhi, destitute of differentiated rhizoids. Lateral hairs comparatively few in number, graceful, tapering, straight, regularly and distinctly septate, at base rich yellow, minutely roughened and varying from $3.5-5.6 \mu$ in thickness, above fading and tapering to a long hyaline, frequently shriveled tip without septa. Terminal hairs forming a broadly spreading head, dark olive to black, regularly and thickly covered with minute spines and globular projections, irregularly and obscurely septate, straight below, spirally coiled above, the convolutions of which, numbering 8-10, are open and of large diameter below, but toward the extremity constantly and evenly decrease in size and become more and more closely appressed. Asci club-shaped, 8-spored, $56.4 \times$ IO $\mu$, pars sporif. $27.4 \mu$. Spores when young colorless with granular contents, when mature, pale dull olive, ovate or lemon-shaped, bluntly pointed at either end, slightly apiculate, $8-8.4 \times 6.4 \mu$, when seen edgewise, $4.8-5.6 \mu$ broad.

Cultivated on mouse dung from Germany (Chivers No. 18).

This is a rare form, having appeared but once. The species may be identified by the distinct blue color of the plant when seen with the naked eye or hand lens, and by the long, spreading and drooping, terminal hairs, the long series of coils tapering abruptly to a blunt point.

9. Chaetomium subspirale Chivers, Proc. Am. Acad. 48: 84 . I9I2

\section{Plate I3, Figs. I2-I7}

Gray, or gray with pink tint. Perithecia rather large, elongated, somewhat barrel-shaped, $314 \times 213 \mu \quad(300-337 \times 206-$ 224), provided at maturity with an irregular blue-black spore mass which almost entirely conceals the terminal hairs, producing at or near the base a heavy, dense mass of olive-brown to black rhizoids. Lateral hairs numerous, only very slightly tapering, slender, graceful, comparatively short, regularly and distinctly septate, smooth, near base dark olive and about $3.7 \mu$ in thickness, straight, above fading and becoming extremely refractive, twisting near the end into a very small and tightly coiled spiral. Terminal hairs slender, graceful, obscurely septate, smooth, 
below dark olive, straight and about $3.7 \mu$ in thickness, above fading to light olive-yellow or becoming colorless, and spirally coiling at first tightly, finally becoming extended and drawn out into a twisted thread. Asci club-shaped, 8-spored, $45 \times 9.7 \mu$, pars sporif. $24 \mu$. Spores pale olive, lemon-shaped, apiculate at both ends, $6.4 \times 5.2-5.6 \mu$.

Frequent in cultures of various substrata from New England. Appearing in cultures of dung from Holland and South America (Chivers No. 27).

This species may be easily distinguished by its characteristic hairs; the lateral ones being short, straight, dark below, tightly coiled into a spiral of small diameter, hyaline and refractive at the tips; the terminal ones slender, at first tightly coiled into a fine delicate spiral, later elongated, twisted rather than coiled, and giving the appearance of woolly threads.

io. Chaetomium aureum Chivers, Proc. Am. Acad. 48: 86. I9I2

Plate I I, FIGs. I2-I7

Gray, pale olive, becoming yellow, at length golden-yellow. Perithecia minute, globose or subglobose, often bluntly pointed at the base, I2 $7 \times$ II $5 \mu$ (IIO-I40 $\times$ I05-I23), without differentiated rhizoids, provided with a long, slender, arched or recurved cirrhus. Lateral hairs numerous, slender, straight or flexed, regularly and distinctly septate, olive-yellow, minutely roughened, with nearly equal diameter throughout, $3.5 \mu$ in thickness, broadly arched at tips. Terminal hairs olive-yellow, regularly septate, minutely roughened, straight or slightly re-curved, at base about $3.8 \mu$ in thickness, at tip nearly straight or incurved. Asci club-shaped, 8-spored, $42 \times$ Io $\mu$, pars sporif. $26 \mu$. Spores when young filled with refractive globules, when mature olivebrown, irregularly ovate, apiculate at both ends, $9.8 \times 5.4 \mu$ $(9.4-$ I I $\times 4.7-5.6)$.

On paper, dung and other materials of various kinds from New England (Chivers No. I). In cultures of old paper from Java (R. Thaxter).

The small size and characteristic golden yellow color clearly distinguish this species from all others except $C h$. trilaterale and Ch. fusiforme. From the former of these it differs in that the spores are discharged in long black cirrhi, in the comparative obscurity of the perithecial hairs at maturity, in the incurved 
tips of the terminal hairs, and in the irregular, oval shape of its spores. From the latter species it differs also in producing long, black cirrhi, in the incurved extremities of its terminal hairs and in the size of its spores and their irregular oval shape.

The name of this species suggests the characteristic goldenyellow of the mature plant, but the color usually disappears as the plants grow old or as they are dried for herbarium specimens, and the highly colored perithecium becomes black. Moreover the cirrhi of spores are frequently so long that they overturn the perithecium.

i . Chaetomium fusiforme Chivers, Proc. Am. Acad. 48: 87 . I9I 2

\section{Plate il, Figs. 7-II}

Gray or pale olive. Perithecia minute, globose or ovate with a bluntly pointed base, I20 $\times$ I02 $\mu$ (II6-I23 $\times$ IOI-I25), without cirrhi, producing at base a few yellow rhizoids. Lateral hairs numerous, slender, flexed, not spirally convolute, regularly and distinctly septate, olive-yellow, minutely roughened, about $2.5 \mu$ in thickness at base. Terminal hairs stouter and more darkly colored than the lateral hairs, minutely roughened, olivebrown, regularly and distinctly septate, nearly straight or incurved, about $3.7-4 \mu$ in thickness at base, at tip circinate or slightly convolute. Asci club-shaped, 8 -spored, $48 \times$ I I $\mu$, pars sporif. $32 \mu$. Spores when young filled with refractive globules, when mature olive-yellow or olive-brown, long, narrow, somewhat fusiform, round or apiculate at the ends, I5.8 $\times 5.4 \mu$ ( $\mathrm{I}_{5}-\mathrm{I} 6$ $\times 4.8-5)$.

A rare species having appeared only once on paper from Alabama, Herb. R. Thaxter (Chivers No. 3).

The long narrow spores distinguish this form from all other species of Chaetomium. In general characteristics it most nearly resembles $\mathrm{Ch}$. aureum and $\mathrm{Ch}$. trilaterale, but differs from both in the long, slender, fusiform spores.

I2. Chaetomium trilaterale Chivers, Proc. Am. Acad. 48: 87. I9I 2

Plate i I, Figs. I-6

Olive-yellow. Perithecia minute, globose or ovate with a bluntly pointed base, I06 $\times 94 \mu($ I $00 \times 90-97)$, without cirrhi 
or differentiated rhizoids. Lateral hairs numerous, graceful, rather long, regularly and distinctly septate, golden-yellow, at base straight, minutely roughened and about $2.8 \mu$ in thickness near tips, smooth and I-3 spirally convolute. Terminal hairs stouter and more darkly colored than the lateral ones, dark oliveyellow, minutely roughened, lower portion about $4 \mu$ in thickness, plainly septate, strongly curved, at tips I-3 spirally convolute with scattered septa. Asci club-shaped, 8-spored, $50 \times 9.5 \mu$, pars sporif. $26 \mu$. Spores when young hyaline with obscure globules, when mature rich olive-yellow to olive-brown, having the shape of a section of an orange, slightly apiculate at both ends, $9.5 \times 5.5 \mu(8.9-9.7 \times 5.2-6)$.

This species has appeared only once, on paper, from New England, Herb. R. Thaxter (Chivers No. 2).

This species has certain characteristics in common with Ch. aureum and Ch. fusiforme. From the former it differs in the more numerous, stout, I-3 spirally convolute, terminal hairs; the spirally coiled lateral hairs; the smaller size and unusual shape of the spores. From the latter species it differs in the convolute lateral hairs, the shape of its spores and their smaller size.

I3. Chaetomium funicolum Cooke, Grevillea I: i76. 1873 Chaetomella Cavallii Mattirolo; Savoia, Il Ruwenzori I: [3]. pl.3, f. $I-3$. I909.

Chaetomium Bartholomaei Saccardo \& Sydow; Saccardo, Syll.

Fung. I4: 490. I899.

Chaetomium setosum Ellis \& Everhart, Am. Nat. 31: 340. 1897.

\section{Plate 7, Figs. 9-19}

Black. Perithecia small, ovate to globose, I $49 \times 147 \mu$ (I30-I57 $\times$ I30-I58), firmly attached to the substratum by dark olive to black rhizoids, frequently provided with long, straight or curved cirrhi. Lateral hairs comparatively numerous, smooth or irregularly roughened by short, blunt projections, stiff, spine-like, dark olive-brown to black nearly to tip, hyaline and crumpled at tip, rarely and obscurely septate, about $4 \mu$ in thickness at base. Terminal hairs forming an especially dense, compact head, dichotomously branched with narrow, acute angles, frequently alternately constricterl and inflated throughout, roughened over entire length by spines and irregular projections, near base dark olive-brown to black and about $6.3 \mu$ in thickness, 
fading to light brown, pale olive, or colorless tips, at maturity bearing on the most remote branches clusters of refractive needles. Asci club-shaped, 8 -spored, $33.7 \times 8$.I $\mu$, pars sporif. I6 $\mu$. Spores when young greenish hyaline, refractive, filled with globules, when mature dark, rich, olive-brown, egg-shaped to lemonshaped, slightly more pointed at one end, apiculate at both ends, $6.3 \times 4.7 \mu(5.6-6.4 \times 4-4.8)$.

Exsiccati.-Sub Ch. setosum Ell. \& Ev.: Fung. Columb. XII, I $126 ;$ N. A. F. 2d Ser. XXXV, 3423.

A rather common species, having been found in cultures of brazil nuts at Cambridge, on straw from Nairobi, Congo, on corn stalks from Cambridge, and on old fruit from Germany (Chivers No. I6). Reported by Peck on an old broom at Albany, New York. Reported also as Ch. setosum E. \& E. by Ellis, and as Chaetomella Cavallii by Mattirolo on paper. Type locality: British Museum; on twine (W. Carruthers).

The writer is indebted to the Royal Botanic Gardens at Kew for type specimens of this species which was first described by Cooke in 1873 as Ch. funicolum or "Twine Bristle Mould," and which has since been found and reported by several writers in various localities. Although the species seems to have been clearly characterized by Cooke, Ellis (35) redescribed it in I 897 under the name $C h$. setosum, in apparent ignorance of the fact that Winter (II2) had previously used this combination for an entirely different plant. Authentic specimens examined in the exsiccati mentioned below are found to be identical with $\mathrm{Ch}$. funicolum Cooke. In I90I Saccardo changed the name to Ch. Bartholomaei in honor of the collector who sent the specimens to Ellis.

Although no specimens have been available the writer is convinced that the plants which M. Mattirolo (6r) described and figured in 1909 under the name Chaetomella Cavallii are identical with Cooke's species. It was discovered in considerable numbers on a piece of paper which wrapped some moss. Mattirolo stated that, considering the present confusion of literature in the genera Chaetomella and Chaetomium, he thought it best to assign his species to the genus Chaetomella. In spite of every attempt, he could not determine whether the spores were produced in true perithecia or pycnidia or whether in an ascus or on a basidium. His three figures show a young perithecium, a branched terminal 
hair, and several spores, all of which are identical with corresponding structures in Ch. funicolum Cke.

This species may be confused on the one hand with Ch. elatum from which it differs by the small size of its perithecium and spores. On the other hand it will be confused with Ch. indicum. In Ch. funicolum the perithecium during its early development is clothed throughout with long, straight, stiff, black, spine-like hairs which are more conspicuous than in Ch. indicum and whose tips frequently appear above the mass even at maturity. Later the terminal hairs (of one type only) grow up, branching by narrow, acute angles, until a compact head is formed. The greenish-gray and powdery appearance of the plants is due in part to the large number of colorless hair tips and also to the bundles of crystals on the ultimate branches. These characteristics, present also in Ch. indicum, make it more difficult to separate the two species.

i4. Chaetomium indicum Corda, Icones 4: 38. pl. 7, f. 104. I 840

Chaetomium melioloides Cooke \& Peck; Peck, Rep. New York State Mus. Nat. Hist. 27: I06. I875.

Chaetomium setosum Winter, Hedwigia 26: I6. 1887.

\section{Plate 7 , Figs. I-8}

Black. Perithecia small, globose to verruciform, $\mathbf{I} 80 \times \mathbf{I} 60 \mu$ (105-200 $\times$ IOI-I 75), firmly attached to the substratum by dark olive-brown to black rhizoids. Lateral hairs comparatively few, rather rigid, septate, tapering to a blunt point or drawn out into a long, hyaline, collapsed tip, at base dark olive-brown to black, and about $5.3 \mu$ in thickness. Terminal hairs of two types which can best be clearly distinguished by studying the perithecium at different ages; (a) hairs which first appear from the top of the perithecium and which do not form a dense mass, stout, dichotomously branched with branches reflexed and roughened by spine-like projections, at base dark olive-brown to black and about $7.5 \mu$ in thickness, fading only slightly or becoming hyaline at the terminal branches; $(b)$ hairs which appear later, forming at first a tuft about the ostiole, profusely branched by narrow acute angles, branches never reflexed, alternately constricted and inflated, light olive-brown or yellow, finely roughened, terminal branchlets encrusted with clusters of acicular or prismatic crystals. 
Asci club-shaped, 8 -spored, $30 \times 9.4 \mu$, pars sporif. $16.5 \mu$. Spores hyaline when young and filled with refractive greenish globules, when mature dark, rich olive-brown, ovate to lemon-shaped, slightly apiculate at one or both ends, $5.5 \times 4.5 \mu\left(5.3^{-} 7 \times 4.5^{-}\right.$ 5.6), when seen edgewise, compressed, $4.2 \mu$ broad.

On culture in laboratory, Cambridge, Massachusetts, R. Thaxter (Chivers No. I4). Reported by Spegazzini from Parque de la Plata, Argentine, and by other authors from France and Germany. Reported also as Ch. melioloides by Cooke and Peck, on old stems of Indian corn, North Greenbush, New York, and as Ch. setosum by Winter on branches of Berberis buxifolia in Patagonia. Type locality: India, Tenasserim, Maulmain; on rotten paper (Dr. Helfer).

While this species seems to have been clearly described and figured by Corda, it has since been re-described by Cooke and Peck in 1875 as Ch. melioloides, and by Winter in 1887 as Ch. setosum.

The writer must here acknowledge his indebtedness to Dr. Charles Peck for his generosity in furnishing specimens of $\mathrm{Ch}$. melioloides as well as several other of his species. In answer to inquiry regarding the possible identity of $C h$. melioloides with Corda's Ch. indicum, Dr. Peck kindly sketched with a camera typical hairs and spores, and wrote as follows: "The two species certainly run close together and if I were inclined to overlook small differences I could easily make myself believe that they are forms of one species. I notice, however, that the spores of $\mathrm{Ch}$. indicum are more elliptic as required by the description of the species, and that they run a little longer than in our plant. But I never would think of describing them as acute at each end. Can this be a mistake in the description or is it due to culture modifications?" After a very careful examination of the two plants, the present writer is convinced that the two are identical and that Dr. Peck's name should appear as a synonym to Ch. indicum. The hairs as sketched by Dr. Peck and the spores as studied in mounts from the type specimen are typical of Corda's species.

Through the kindness of $\mathrm{M}$. Hariot the writer has been able to study Ch. setosum Winter, and it has been found that the plant thus named is identical in every way with $\mathrm{Ch}$. indicum $\mathrm{Cda}$. It produces the same dichotomously branched hairs with widely 
spreading branchlets, and spores of the same shape and size. The statement made by Palliser in North American Flora (p. 63), where $C h$. indicum Zopf is listed as a synonym under Ch. setosum Wint., to the effect that Ch. setosum Wint. is the same as $C h$. indicum Zopf, but not the same as Ch. indicum Cda., is not easily understood, since Zopf in Nova Acta (p. 279) simply copied Corda's description of Ch. indicum, and made no statements which seem in any way at variance with Corda's original description.

On the one hand this species may be confused with Ch. elatum, from which it differs in the small size of its perithecium, the spreading or reflexed branches of the terminal hairs, and by its spores which have much smaller dimensions. On the other hand it may be confused with Ch. funicolum, especially when only the mature stage is studied. In its younger condition $\mathrm{Ch}$. indicum is covered throughout with straight, spine-like hairs, the lateral ones only of which are visible at maturity. Later terminal hairs appear with branches spreading or reflexed, and still later, hairs which branch by narrow angles and which grow up among the branches of those already formed. In this way a dense head is formed consisting of innumerable branches, and the identity of the hairs is more or less concealed. The plant finally has a greenish-gray and powdery appearance similar to that of $\mathrm{Ch}$. funicolum Cke., due in part to the large number of refractive hair tips and also to the clusters of crystals on the ultimate branches.

I5. Chaetomium elatum Kunze \& Schmidt, Deutsch. Schwäm. 3. I818; Fries, Syst. Myc. 3:253. I829

Chaetomium atrum Link; Linnaeus, Spec. Plant. Ed. 5, I : 40. I824. Chaetomium atrum, var. distinctum Roumeguère, Rev. Myc. 8: I98. I886. Not Chaetomium atrum, var. Therryana Roumeguère \& Patouillard, Rev. Myc. 5: 29. 1883.

Chaetomium comatum (Tode) Fries, Syst. Myc. 3: 253. I829.

Not Chaetomium comatum, var. helicotrichum Saccardo, Michelia I: 222. $\quad 1878$.

Chaetomium comatum, var. ligni Roumeguère, Fung. Gall. LXIV, 6309.

Chaetomium Fieberi Corda, f. chartarum Roumeguère, Fung. Gall. LIX, 5827. I 891 . 
Chaetomium Fieberi Fuckel, Symb. Myc. 90. I869. Not Ch. Fieberi Corda.

Chaetomium glabrescens Ellis \& Everhart, Proc. Acad. Nat. Sci. Phil. I893: I30. I893.

Chaetomium graminicolum Fuckel, Fung. Rhen. VII, 647. 1863. Chaetomium graminis Rabenhorst, Bot. Zeit. 34: 569. I85I.

Chaetomium lageniforme Corda, Icones I: 24. pl. 7, f. $293 \mathrm{~A}$. I 837 .

Chaetomium Libertii Roumeguère \& Patouillard, Rev. Myc. 5: I5. pl. 35, f. 2. I883; Fung. Gall. XXIV, 2376.

Chaetomium pannosum Wallroth, Flora Crypt. German. 2: 267. I 833 .

Chaetomium velutinum Ellis \& Everhart, Jour. Myc. I: 90. 1885. Conoplea atra Sprengel, Syst. 4: 554 .

Conoplea atra Persoon, Syn. Fung. I: 235. I80I.

Sphaeria comata Tode, Fung. Mecklenb. 2: I5. I79I.

\section{Plate 6, Figs. I-5}

Black. Perithecia large, ovate, $435 \times 391 \mu$ (4I 8-500 $\times 334^{-}$ $45 \mathrm{I}$ ), seated on a subiculum of dark olive-brown to black rhizoids which most frequently hold the perithecia in place through old age. Lateral hairs numerous, long, slender, graceful, unbranched, near the base dark olive-brown to black, coarsely roughened and about $5 \mu$ in thickness, gradually tapering and fading to slender, pale to hyaline smooth tips which are obscurely septate. Terminal hairs extremely coarse, conspicuously roughened throughout with irregular pyramidal projections and blunt spines, once or twice dichotomously branched with the branches widely spreading and often reflexed and once or twice irregularly forked by an acute angle, at base black and about $9.5 \mu$ in thickness, tapering and fading to slender, hyaline tips. Asci broadly and irregularly club-shaped, 8 -spored, $64-75 \times$ i $7 \mu$, pars sporif. $34 \mu$. Spores hyaline to light olive when young, when mature dark, rich, olive-brown, lemon-shaped, apiculate at both ends, I2.8 $\times 8.7 \mu(\mathrm{I} 2-\mathrm{I} 3 \times 8.4-9.5)$, when seen edgewise, compressed, $7.4 \mu$ broad.

Exsiccatı.-Brit. Fung. I, 49; Deutsch. Schwäm. I84; Erb. Crit. Ital. XVII and XVIII, 877; Fung. Aust. X, 989; Fung. Bavar. X, 927; Fung. Brit. I, Ioo, and III, 290; Fung. Carol. III, 66; Fung. Columb. VII, 62I, and XI, I034; Fung. Europ. VI, 529, XII, II47, and XXVI, 2527; Fung. Fenn. IX, 820, and 
X, 980; Fung. Gall. I, 66, and XV, I 428 ; Fung. Rhen. VII, 646; Fung. Rossiae II, 83; Fung. Sax. XVII, 834; Herb. Crypt. Belg. I, 83; Herb. Myc. I, 58; Klotzsch. Herb. Viv. Myc. XI, I032; Myc. March 343, 4534, 475I; Myc. Univ. VIII, 758; N. A. F. VI, 560; Pl. Crypt. de Fr. Set. I, V, 237 ; Rehm. Asc. 247b; Schweiz. Krypt. XI, 526; Sub Ch. atrum Link: Fung. Gall. IV, 325; M. \& N. Stirp. XV, I483; Pl. Crypt. de Fr. Set. III, II, 86. Sub Ch. atrum Link, var. distinctum Roum.: Fung. Gall. XXXIX, 3883. Sub Ch. atrum Link, var. Therryana Roum. et Pat.: Fung. Gall. XXV, 2496. Sub Ch. comatum (Tode) Fr.: Erb. Crit. Ital. Series II, XVI, and XVII, 834; Fung. Gall. X, 975; Jaap, Fung. 372; Krypt. Vind. I8I4; Misc. rar. (Vestergren) LVII-LVIII, I420; Myc. Ital. IX, 84I; Myc. March. 40I6; Myc. Venet. VII, 636. Sub Ch. comatum (Tode) Fr., var. ligni Roum.: Fung. Gall. 64, 6309. Sub Ch. Fieberi Cda., var. chartarum Roum.: Fung. Gall. LIX, 5827. Sub Ch. graminicolum Fckl.: Fung. Rhen., VII, 647. Sub Ch. graminis Rabh.: Klotzsch. Herb. Viv. Myc. XVI, I 555. Sub Ch. lageniforme Cda.: Herb. Myc., Edit. Nova, VI, 52 I. Sub Ch. Libertii Roum. et Pat.: Fung. Gall. XXIV, 2376. Sub Ch. murorum Cda.: Fung. Europ. Series II, Edit. nova, III, 234. Sub Ch. pannosum Wallr.: Fung. Europ. Series II, XXI, 2025; Fung. Gall. I, 6I ; Herb. Myc., Edit. Nova., VIII, 748; Klotzsch. Herb. Viv. Myc. XVI, I556; Myc. March. I548, 4752; Мyc. Ital. XV, I 475 .

This is a very common and widely distributed species, having appeared on substrata of very varied character such as old rope, straw, paper, barrel hoops, old brooms, and on the dung of different animals. The writer has found this species on such materials from many localities in New England, and from the Carolinas, Maryland, California, Illinois, New Jersey, and Pennsylvania; also from Switzerland, Germany, and the Galapagos (Chivers No. 15). The species has also been reported by many other authors from different localities in North America, from England, Scotland, Russia, and from many places in Europe.

There is no species of Chaetomium, with the possible exception of Ch. globosum Kze. which has received so much attention as Ch. elatum, and while the characteristics described by Kunze 
and figured by Greville seem to be very clear, the form has been re-described under many different names and confused many times with other species.

In 18 I 8 Kunze gave the name Ch. elatum to specimens which were collected in the spring at Halle, Germany, on dead leaves of Typha and Sparganium, and which also occurred commonly on dried stems and leaves of the Aroidaceae and Gramineae. He called attention to the simple, unbranched hairs of the perithecium near the base, and the very long, rigid, branched hairs above, and while he gave no measurements of spores, he described their shape as oviform or globose.

In 1826 Greville (43) published a diagnosis of Kunze's Ch. elatum accompanied by six figures, and while the description contains no more information than that of Kunze, the figures are instructive.

In $1824 \mathrm{H}$. F. Link (54) published a note included in a brief comment on the Conopleae, to the effect that Conoplea atra Persoon is Chaetomium atrum, and in I 853 Desmazières (26) made the following statement: "According to specimens which we have received from M. Persoon, his Conoplea atra is surely a Chaetomium and not the Myxotrichum chartarum Fries [38, p. 349] thought it to be." It should here be stated that in connection with his specimens Desmazières listed Conoplea atra Persoon as a synonym under Ch. atrum Link, and indicated that he had verified the synonymy. The very generous specimens of $C h$. atrum, which were distributed by Desmazières, have been examined and found to be typical in every way of Ch. elatum Kze. It may be seen, therefore, that Conoplea atra Persoon is identical with Ch. atrum (Persoon) Link, and with Ch. elatum Kze.

In I829 Fries (38) gave to the Sphaeria comata of Tode (I03) the new name Ch. comatum, and the use of this and of Kunze's older name, Ch. elatum, has varied with later authors. In many cases the former has been arranged as a synonym under the latter, but Saccardo (79, p. 22I) and several other authors prefer the use of Ch. comatum (Tode) Fr., with Ch. elatum listed as a synonym thereto. While Fries published no figures there seems to be no doubt that his form is identical with Kunze's species, and since adequate description and figures of this plant under the name 
Ch. elatum were published by Kunze and Greville previous to the time Fries introduced the name comatum into the genus, and so far as the present writer is aware, no figures under the name $C h$. comatum have ever appeared, it seems best to arrange Ch. comatum as a synonym under Ch. elatum Kze.

In 1833 this plant was re-described by Wallroth under the name Ch. pannosum. Zopf (II3) in I88I listed and figured Wallroth's species, and stated in connection with his description of Ch. elatum Kze. that the two forms differed on account of the fact that in the former the mycelium was red brown, while in Ch. elatum it was a golden color. His figures of Ch. pannosum, however, show characteristics identical with those of Ch. elatum, and even though the present writer, in all cultures of this plant, has found the mycelium varying only from white to yellow and greenish-yellow, he is inclined to disagree with Zopf regarding the separation of these forms into two species, and rather to list $C h$. pannosum as a synonym under Ch. elatum. The writer is led to question if color-producing bacteria which so easily contaminate cultures, or some change such as peculiar fading induced by the environment or substratum, would not account for the appearance which Zopf found in his cultures.

The species was re-described and figured by Corda in 1837 as Ch. lageniforme, and again by Rabenhorst in I85I as Ch. graminis. While Rabenhorst speaks of the hairs of his species as somewhat simple and not intertwined, it has been found from a study of authentic exsiccati specimens, in Klotzsch. Herb. Myc. No. I555, that they are no less branched nor intertwined than in Ch. elatum.

Fuckel (40) listed this plant in I86I as Ch. graminicola and distributed specimens under that name in Fungi Rhenani No. 647. It should be stated here that Fuckel used Rabenhorst's name in connection with his specimens. It has been impossible to find any reason for the use of the name graminicola. The writer is led to the conclusion that graminis is the basis for this usage and that Fuckel has mistaken this for graminicola. The form to which Fuckel in 1869 called attention in the Symbolae Mycologicae (p. 90) under the name Ch. Fieberi is without question identical with Ch. elatum. 
In I883 Roumeguère and Patouillard redescribed the species as Ch. Libertii. The writer has examined authentic exsiccati specimens of this form in Fung. Gall. No. 2376, and it is not clear to him why in their diagnosis, the authors compared and contrasted it with Ch. crispatum, since it does not bear the slightest resemblance to that species.

In 1885 Ellis gave the name Ch. velutinum to specimens which were collected by Carpenter on a damp maple log, but in North American Pyrenomycetes (32, p. I24) the same author lists Ch. velutinum as a synonym under Ch. pannosum. According to the arrangement used by the present writer Ellis's name must be listed as a synonym to $\mathrm{Ch}$. elatum.

In 1886 Roumeguère applied the name $C h$. atrum Link, var. distinctum, to this species which he found growing isolated and arranged in parallel lines on poplar wood. While the preparation which could be obtained from Fung. Gall. No. 3883 was broken and somewhat scanty, it was possible to identify and study the spores and fragments of the branched hairs. The characteristics of these structures were found to vary in no way from those of Ch. atrum Link, and therefore from Ch. elatum Kze. That perithecia should be scattered or that they should appear arranged in lines along the substratum would seem to be conditions which could hardly warrant the separating of a variety from the type form, since such characteristics are likely to appear in any species, especially when the substratum is more or less furrowed as it is in the case of stems.

In I891 Roumeguère distributed specimens of the same plant in Fung. Gall. No. 5827, under the name Ch. Fieberi Cda., f. chartarum. No description was published at that time, however, and so far as can be learned, no mention or diagnosis has since been made. The present writer has examined authentic specimens and has found them to be characteristic of Ch. elatum Kze. in all details. Two years later, in I893, the same author used the name Ch. comatum (Tode) Fr., var. ligni, in Fung. Gall. No. 6309 , for plants which he found on wood. Here again no description is to be found with the specimens and no subsequent mention of them has appeared. It does not seem advisable to retain this name and set apart a variety from the type form simply on 
account of the fact that it was found on wood, especially since a study of the authentic exsiccati specimens shows all structures to be typical of Ch. comatum (Tode) Fr. which, as we have seen, is synonymous with Ch. elatum Kze.

Finally Kunze's species was redescribed by Ellis in 1893 under the name $C h$. glabrescens. It has been possible to examine type specimens of Ellis's species which are now in the possession of Dr. Farlow at Cambridge, and while the mounts contain for the most part rather fragmentary remains of perithecia, and while the hairs in most cases are broken below the point of origin of the first branches, still in other cases clusters of terminal hairs show characteristics identical with those of $\mathrm{Ch}$. elatum Kze. The spores also are typical of Kunze's species both in shape and size.

All exsiccati mentioned above have been carefully examined and with two exceptions have been found to be typical of Ch. elatum. However, only plants of Chaetomidium fimeti (Fkl.) Zopf could be obtained from exsiccati specimens of Ch. atrum Link in Fung. Gall. IV, 325, and of Ch. atrum Link, var. Therryana Roum. et Pat. in Fung. Gall. XXV, 2496. In the specimens of Ch. pannosum Wallr. in Myc. Ital. XV, I475, perithecia of Ch. murorum $\mathrm{Cda}$. appeared in considerable numbers.

The following exsiccati specimens also consist wholly or in part of Ch. elatum Kze.: Ch. chartarum Ehr. in N. A. F. No. I54I ; Ch. Fieberi Cda. in Fung. Gall. No. 6409, Herb. Myc. No. I65, and Myc. Ital. No. I288; Ch. Fieberi Cda., var. chartarum Roum. in Fung. Gall. No. 5827; Ch. Kunzeanum Zopf in Myc. March. No. 3246; Ch. lanosum P. in Fung. Gall. No. 4437; Ch. murorum Cda. in Fung. Europ., Series II, Edit. nova, III, 234; Ch. olivaceum Cke. and Ellis in Myc. Univ. No. I942 and in Fung. Columb. No. 5I2.

No other species with which this should be confused have come to the attention of the writer with the exception of $C h$. indicum Cda. and Ch. funicolum Cke., from both of which it differs in its large size, coarse appearance, and in the greater size of its spores. 
i6. Chaetomium spinosum Chivers, Proc. Am. Acad. 48: 86. I9I 2

Plate io, Figs. I-7

Golden-yellow. Perithecia of medium size, ovate, obovate or subglobose, $290 \times 224 \mu(273-318 \times 206-262)$, frequently provided with a single cirrhus and rhizoids. Lateral hairs numerous, straight, rigid, spine-like, roughened by minute spines or projections which are irregular in shape, at base black or nearly so and about $7.5 \mu$ in thickness, fading to dark olive-brown, terminating in a yellow or colorless, collapsed, hypha-like tip, obscurely septate in upper part. Terminal hairs straight, rigid, acute, at first of the same nature as the lateral hairs, later producing elaborate systems of branches which at first consist of clubshaped out-growths from the main shaft directed either at right angles with it, or backward from it. Later the primary branches become branched until an intricate system is formed. Branches light yellow to colorless, covered with delicate spines. Asci very narrowly club-shaped, $4 \mathrm{I} \times 7.5 \mu$, pars sporif. $22 \mu$. Spores when young filled with granules and globules, greenish, refractive, when mature pale olive, egg-shaped, $5.9 \times 3.9 \mu(5.6-6.4 \times 3.2-4)$.

Growing in cultures of dung from Buenos Ayres, R. Thaxter (Chivers No. 7).

This is apparently a rare species having appeared but once. The egg-shaped spores and the branched, terminal hairs are peculiar to the species. From the dark, stiff, spine-like shafts of the terminal hairs arise slender, delicate, irregularly swollen and constricted outgrowths, from which secondary branches arise which elongate and precede the cirrhus of spores as it forms. In this way a support is formed for the spore mass.

i7. Chaetomium ampullare Chivers, Proc. Am. Acad. 48: 86. I9I 2

Plate io, Figs. 8-I2

Ochre. Perithecia rather large, extremely elongated, flaskshaped, $489 \times 147 \mu\left(45^{6}-532 \times \mathrm{I} 37^{-167}\right)$, producing at maturity a copious, black mass of spores and olive-yellow rhizoids. Lateral hairs comparatively few, long, slender, graceful, straight or nearly so, insensibly tapering, at base dark olive-brown, smooth or very minutely roughened and about $7.5 \mu$ in thickness, above bright yellow, terminating in rather long, colorless, refractive, thin and more or less collapsed tips. Terminal hairs smooth, very long, 
graceful, insensibly tapering, straight for a long distance above the base, distinctly and regularly septate, at base about $7.5 \mu$ in thickness, from base to apex successively golden-brown, goldenyellow, pale yellow, hyaline, terminating in colorless, elongated, more or less collapsed tips, producing in the upper portions branches which are frequently septate and only slightly colored at base, hyaline and delicate above, and which in turn produce branches of like nature. Asci club-shaped, 8-spored, $45 \times 9.7 \mu$, pars sporif. $23 \mu$. Spores bright olive-yellow, umbonate at either end, lemon-shaped, 8.I-8.9 $\times 6.4 \mu$.

On culture of sail cloth from Lowell, Massachusetts (Chivers No. 4). On dung from North Carolina (R. Thaxter).

This species is clearly characterized by the very much elongated bottle-shaped perithecium, and by the terminal hairs which are drawn out into long, hyaline, tangling, easily collapsible threads, the branches of which may be very easily overlooked except with higher magnifications.

I8. Chaetomium cuniculorum Fuckel, Symb. Myc. 89. 1869

Brownish-black. Perithecia spherical, ovate or egg-shaped, $370 \mu$. Terminal hairs few, dark brown at base, lightly colored at tips, twice as long as the perithecium, straight below, stiff, septate, $5^{-7} \mu$ in thickness, seldom branching at the base, more or less encrusted with calcium oxalate, thickly entangled, forming a compact mass about the ostiole, some remaining simple, others branching dichotomously at their summits and anastomosing with each other by their free ends. Lateral hairs straight, rigid, tapering, unbranched. Asci club-shaped, 8-spored. Spores dark olive-brown, elliptical or spindle-shaped, barely apiculate at the ends, $10-12 \times 7-9 \mu$.

Exsiccati.-Fung. Rhenan. I961.

Type locality: Freinweinheim, Germany; on rabbit dung. Reported also by Bainier as occurring very commonly on dung of rabbit.

In spite of repeated attempts it has been impossible to obtain a satisfactory mount from the type material of Ch. cuniculorum Fckl. from the set of Fungi Rhenani at Harvard University. The specimens consist of two rabbit pellets, exposed to the leaves of the book. These pellets are thickly covered with perithecia of Sordaria, but at best only fragments of perithecia of Chaetomium could be obtained. In several cases many bases of hairs could 
be distinguished which were very dark to black below, yellow and finally hyaline and refractive above, clearly septate, and irregularly branched. These hairs were studied with extreme care with the hope that anastomosing branchlets might be found, but none could be seen.

The species was first described by Fuckel, in the Symbolae Mycologicae, in I869, and again by Zopf in his monograph in Nova Acta in I88I, and was finally redescribed and figured by Bainier in his monograph in I910. Since the writer has never found this form and the available type specimens have not been entirely satisfactory, he has been obliged to rely on those mentioned above for his information. Zopf in comparing and contrasting this species with "Ch. Kunzeanum" has stated that the two resemble each other in respect to the dense mass of terminal hairs, but differ in respect to the shape and size of the spores. Bainier has stated that the perithecia are pure white during their earlier stages, and that the terminal hairs may be divided into two groups, those which are $5.6 \mu$ in diameter, long and rigid, and those only I $\mu$ in diameter and only half as long as the first type. He described the spores as dark bluish-gray or greenish.

i9. Chaetomium sphaerale Chivers, Proc. Am. Acad. 48: 84. I9I 2

Plate i I, Figs. I 8-23

Grayish-yellow, olive-yellow, with age golden-yellow. Perithecia rather large, globose or subglobose, evenly rounded at base, distinctly narrowed above, 3I $2 \times 276 \mu(300-329 \times 262-$ 300 ), frequently provided with short, black cirrhi, without rhizoids. Lateral hairs numerous, graceful, slender, regularly and distinctly septate, olive at base, fading toward the tip to goldenyellow then pale yellow, terminating in a colorless, easily collapsible tip, some rather straight and long, I-2 branched, at base about $3.7 \mu$ in thickness, others wavy, rather short, unbranched, at base about $2.8 \mu$ in thickness. Terminal hairs long, slender, graceful, with color as in lateral hairs, smooth, irregularly waved or loosely and irregularly spirally convolute, I-5 branched, at base distinctly septate, at apex obscurely septate or continuous. Asci club-shaped, 8 -spored, $48 \times$ I $3 \mu$, pars sporif. $26 \mu$. Spores when young filled with refractive greenish hyaline globules, when mature dark olive-brown, lemon-shaped to globose, apiculate or umbonate at both ends, $7.3^{-8.1} \times 6.4 \mu$. 
A rare species having appeared only once in a culture of caterpillars from Reading, Massachusetts (Chivers No. 28).

The perithecium, globose below and conspicuously narrowing above, is peculiar to this species. The slender delicate hairs and the entire absence of differentiated rhizoids are also significant characteristics.

20. Chaetomium globosum Kunze, Myc. Hefte i: i5, i6. f. $9 a-d$. I 8 I 7

Chaetomium affine Corda, Icones 4:37. pl. 8, f. IOI. I840.

Chaetomium amphitrichum Corda, Icones 4: 37. pl. 8, f. Iо3. I 840 .

Chaetomium Araliae Corda, Icones 4: 37. pl. 8, f. IO2. I840.

Chaetomium chartarum Ehrenberg, Sylv. Myc. Berol. I5, 27. I 8 I 8 .

Chaetomium cymatotrichum Cooke, Grevillea I2:2I. I883.

Chaetomium Elasticae Koorders, Verhandd. d. K. Akad. v. Wetenschappen te Amsterdam (Tweede Sectie) I3 $3^{4}$ : I85. f. I6. I907.

Chaetomium Fieberi Corda, Icones I : 24. pl. 7, f. 293c. I 837.

Chaetomium Fieberi.Corda, var. chlorina Saccardo, Myc. Venet. X, 906, I 876; Michelia I : 27. I 877 .

Chaetomium Fieberi Corda, *** Saccardianum Bommer \& Rousseau, Misc. Myc. I: I7. I884. Not Chaetomium Fieberi Fuckel.

Chaetomium Kunzeanum Zopf, Nova Acta Acad. Leop.-Carol. 42: 278. pl. I5. I88I.

Chaetomium Kunzeanum, var. chlorina "Mich." Bull. Soc. Myc. France 25: 202. pl. I3, f. I-4. I9IO.

Chaetomium Kunzeanum, var. fimicolum Bommer \& Rousseau, Bull. Soc. Roy. Bot. Belgique 23: 207. I 884.

Chaetomium lanosum Peck, Rep. New York State Mus. Nat. Hist. 28: 64. I876.

Chaetomium macrosporum Saccardo \& Penzig, Michelia 2: 59I. I 882 .

Chaetomium megalocarpum Bainier, Bull. Soc. Myc. France 25: 202. pl. I6, f. I-4. I9Iо.

Chaetomium olivaceum Cooke \& Ellis, Grevillea 6: 96. pl. Ioo, f. 38 . 1878 . 
Chaetomium olivaceum, var. chartarum Ellis \& Everhart, N. A. Pyren. I25. I892.

Chaetomium olivaceum, f. chartarum Roumeguère, Rev. Myc. II : I30. I 889 .

Chaetomium oospora Beauverie, Ann. Univ. Lyon, Nouv. Sér. I. 3: 20I-2I8. I900.

Chaetomium orientale Cooke, Grevillea 5: I03. pl. 86, f. II. I877. Chaetomium setosum, Bainier, Bull. Soc. Myc. France 25: 209. pl. I $8, f \cdot 3-7$. I9I0.

Chaetomium spirilliferum Bainier, l. c. 25: 207. pl. I6, f. I-4. I9IO.

Chaetomium undulatum Bainier, l. c. 25: 208. pl. I6, f. 4-7. I910.

Plate I0, Figs. I3-I6; Plate I5, Figs. 9-I4

Gray, green, chocolate brown, or olive-brown. Perithecia rather large, variable in shape, somewhat elongated or subglobose with a bluntly pointed base, when young yellow, translucent, allowing the cellular structure of the wall to appear, when mature opaque, black, $225^{-250} \mu\left(205^{-320} \times 205^{-280}\right)$, frequently producing short, black cirrhi, and seated on a thick mass of dark olive to black rhizoids. Lateral hairs numerous, slender, graceful, plainly or obscurely and remotely septate, minutely roughened with spines, at base rather dark olive-brown with maximum thickness of about $3.7 \mu$, light olive or hyaline at tip, straight or only slightly flexed, or more slender and undulate or even kinked. Terminal hairs extremely numerous, and intricately interwoven forming a neat, rather compact head, or in age spreading and drooping even to the substratum, or to the hairs of neighboring perithecia, slender, graceful, without septa, minutely roughened with spines throughout, about $3.5 \mu$ in thickness and dark at base, dark olive through greater part of length, with tapering and pale yellow to hyaline tips, wavy or undulate or kinked. Asci irregularly club-shaped, 8 -spored, $64 \times 13 \mu$, pars sporif. $37 \mu$. Spores when young colorless, filled with several large, refractive globules, when mature dark, rich, olive-brown, varying in shape from broadly ovate or subglobose to lemon-shaped, or fusiform, with ends apiculate or umbonate or nearly rounded, varying also in size, $10.5 \times 8.5 \mu\left(9.5^{-1} 3 \times 6.3^{-9.5}\right)$, when seen edgewise, frequently compressed, $7.3 \mu$ broad.

Exsiccati.-Fung. Gall. XLV, 4438; Klotzsch Herb. Viv. Myc. X, 959. Sub. Ch. chartarum Ehrb.: Fung. Austro-Americani, I93; Fung. Brit. IV, 328; Fung. Gall. XI, I090; Micro.- 
Fung. Brit. 475; N. A. F. 2nd Series, I54I. Sub Ch. Fieberi Cda.: Fung. Gall. LXV, 6409; Herb. Myc., Edit. Nova, II, I65; Myc. Ital. XIII, I288. Sub Ch. Fieberi Cda., var. chartarum Roum.: Fung. Gall. LIX, 5827. Sub Ch. Fieberi Cda., f. lignicola chlorina Sacc.: Myc. Venet. X, 906. Sub Ch. Kunzeanum Zopf: Fung. Gall. XLV, 4436; Fung. Longob. I, 3I; Myc. March. 3246. Sub Ch. lanosum Peck: Fung. Gall. XLV, 4437. Sub Ch. olivaceum C. \& E.: Fung. Columb. VI, 5I2; Myc. Univ. XX, I942; N. A. F. I, 56. Sub Ch. olivaceum C. \& E., var. chartarum Roum.: Fung. Gall. L. 4930.

A very common species of Chaetomium, having been found on substrata of very varied nature in nearly all countries (Chivers No. 26). Type locality: Leipzig; on dead stalks and leaves of various plants.

Probably no species of Chaetomium is of so common occurrence as $C h$. globosum, and certainly no other has been given so much attention both from a systematic and a morphological point of view. It was first described and figured by Kunze as a type form of his new genus, having appeared often in company with Sphaeria doliolum on dead stalks and leaves of various plants, in damp wet places in Leipzig, during the spring and autumn. It was described by that author as a globular fungus, a fourth of a line in size, black when in fresh condition, and entirely covered with hairs. His four very simple figures illustrate: a comparatively young plant; a later stage when under the influence of moisture a punctiform opening appears at the crown of the fungus; a group of somewhat spherical transparent spores which were mixed with a gelatinous mass; and a cross-section through the body of the closed fungus.

While, as may be seen, Kunze's description is of a general and indefinite nature, and his figures are quite inadequate for a sure identification of the form with which he worked, it seems reasonable to conclude that it is the same which Zopf described and figured in his monograph as Ch. Kunzeanum. For reasons not stated, but presumably on account of the fact that the term globosum might be applied to any one of several species, Zopf believed Kunze's form to be poorly named, and considered the alternative of retaining the old name though unsatisfactory or of 
giving an entirely new name, in which latter case he would be disregarding a proper respect of the original author. He finally named Kunze's species Ch. Kunzeanum in honor of the founder of the genus. It would hardly seem that this change was justified, and in the present monograph, therefore, Zopf's Ch. Kunzeanum appears as a synonym under Ch. globosum Kze.

In 1818 Ehrenberg added the name Ch. chartarum, the description of which is indefinite and without figures. No mention is made of spores and the statements regarding the hairs and perithecia are of a most general nature. A description and figures of this species were published by Corda (23) in I840, and there seems to be little doubt that the plant in question is identical with $C h$. globosum of Kze. Since Ehrenberg's time certain writers have retained the name Ch. chartarum, but as it is reasonably certain that Ehrenberg's species is identical with that of Kunze, it seems most reasonable to list Ch.chartarum as a synonym under Ch. globosum Kze.

In 1837 and 1840 , in the Icones Fungorum, Corda described and figured four new species of Chaetomium: Ch. Fieberi, Ch. affine, Ch. amphitrichum, and Ch. Araliae. The simple, wavy, undivided hairs and the characteristic spores as described and figured would indicate that $C h$. Fieberi is beyond a doubt identical with Ch. globosum Kze. The recognition of the three remaining species is not so easy, however, but it seems entirely possible that all these are forms of the same plant and should be listed under Ch. globosum Kze. Corda himself stated that Ch. affine is similar to Ch. globosum but was to be distinguished from it by the inverted egg-shaped spores. Zopf listed this in his monograph as a synonym to his Ch. Kunzeanum. Corda stated that Ch. Araliae and Ch. amphitrichum are distinguished from all other species of the genus described up to that time by the light color of their spores, but in his diagnoses these spores are given characteristics not unlike those of other species. In two of the three diagnoses under consideration he failed to give the sizes of spores, a fact which makes a sure determination more difficult. If his figures and descriptions are studied with care it will be found that, with the exception of the egg-shaped spores of Ch. affine, and slight differences in the shape of the hairs in the general figures of the three 
species, the forms are very similar, and while it is singular that he should call these species new unless he felt satisfied that they possessed sufficient distinguishing characteristics, especially since he had already named $C h$. Fieberi, which has all the characteristics of Ch. globosum, still it does not seem unreasonable to the present writer to place these forms as synonyms under $C h$. globosum Kze., on the ground that Corda was dealing with different stages of the same plant.

In 1876 Dr. Peck redescribed Kunze's species under the name Ch. lanosum. Mounts of original specimens which were received from Dr. Peck show the perithecia and spores typical in all their characteristics of the younger stages of $\mathrm{Ch}$. globosum Kze. It may be well at this point to call attention to the fact that the Ch. lanosum Peck, in Roumeguère's Fung. Gall. No. 4437 , is identical with the plant which Zopf described under the name Chaetomidium fimeti (Fckl.).

The writer can hardly agree that it is desirable to apply the name Ch. Fieberi Cda., f. lignicola chlorina to the plant which Dr. Saccardo found on moist wood, and which he described in I876, for the form seems in every way to be typical of Ch. globosum Kze. If one examines young stages of Kunze's species one frequently finds hairs which are straight for a considerable portion of their length, then taking a somewhat hooked turn, beyond which they become wavy. The same hooked characteristic is mentioned by Saccardo in his original description, but it may be seen from an examination of original material received from Dr. Saccardo, and from authentic specimens in Myc. Venet. X, No. 906, that such is true not of the mature perithecia, where the hairs are like those of $C h$. globosum, but in the young immature plants. As for the color, it may be said that it is typical of Kunze's species, and that the plant was growing on moist wood seems to be insufficient cause for setting it apart as a variety, especially since $C h$. globosum will thrive on almost any substratum so long as it is moist.

In I 877 Dr. Cooke described Ch. orientale, mounted material of which has been placed at the disposal of the writer through the kindness of the Royal Botanic Gardens at Kew. An examination of that material shows, in spite of the fact that the perithecia are 
rather fragmentary, characteristics which are those of $\mathrm{Ch}$. globosum, namely, olive-colored perithecia, simple flexuous hairs, and globose spores with slightly apiculate ends. The figure accompanying Cooke's original description shows the same characteristics.

In 1878 Cooke and Ellis gave the name Ch. olivaceum to a form which they found on rotting stems of Erigeron. It was at first thought by the present writer that this name could be associated with a species which he has found frequently and which has apparently been recognized for the first time by Palliser (67) as distinct from Ch. globosum Kze. This does not seem to be true however, and from detailed study of the original description and an examination of mounts made from the type material, one is forced to conclude that Ch. olivaceum C. \& E. is identical with Ch. globosum Kze. It should be stated that the plants in each of the specimens of type material in three different herbaria are past maturity. Dark, rich olive, umbonate spores, and larger, much more lightly colored, apiculate spores, are to be found in both Ch. olivaceum and Ch. globosum, the former type appearing more commonly in Ch. olivaceum, the latter in Ch. globosum. The hairs in Cooke and Ellis's material, while old and for the most part frayed out, are typical of Kunze's species.

As a result of careful study of type specimens of Ch. macrosporum, which was described by Saccardo and Penzig in I882, and which has been received from Dr. Saccardo, it has been found that this species possesses characteristics sufficiently similar to those of Ch. globosum to warrant placing it as a synonym under that name. According to Saccardo's description the hairs of the perithecium are olivaceous and flexuous, but the spores measure $14-16 \mu$. The original material was set apart into two parcels; the one containing plants which prove to be typical of the young Ch. globosum, the other typical mature plants of the same species. The spores which belong to the mature perithecia do not have the size indicated by Saccardo, but measure, as for Ch. globosum Kze., 10.5-12.5 $\mu \times 9.5 \mu$. There are, however, intermingled with these plants the perithecia and spores of $\mathrm{Ch}$. murorum Cda. Here may lie an explanation for the error made by the original writers, for the spores of $\mathrm{Ch}$. murorum correspond 
exactly to the measurements recorded in the diagnosis, I4-I6 $\mu$ $\times 7-8 \mu$. The presence of $C h$. murorum Cda. may also explain the statement that the species is somewhat allied to Ch. crispatum Fckl., for the perithecia are old and the hairs are very dark, almost opaque, and except for the circinately coiled tips, have somewhat lost their true characteristics.

It becomes evident from a study of the original description of Ch. cymatotrichum made by Dr. Cooke in I883, and from an examination of mounts of type material supplied by the Royal Botanic Gardens at Kew, that this is identical with Ch. globosum Kze.

The writer has recently received from Dr. Saccardo specimens of Ch. Fieberi Cda., subspecies Saccardianum, described by Bommer and Rousseau in I884 (78), and which according to Saccardo $(84$, p. 86$)$ is equivalent to Ch. Saccardianum. While the plants are not in the best of condition it has been possible to determine with a reasonable degree of certainty that this variety is identical with Ch. globosum Kze. It is stated in the original description that the perithecia finally collapse and become cupshaped. This is true in nearly all of the perithecia examined. The terminal hairs have been worn away and the shiny, black perithecial walls have collapsed. It is also stated that the hairs bear rough spherical conidia. While it is not possible to determine the origin of these conidia which are scattered among the rhizoids and perithecial hairs, the writer has no hesitation in concluding that these are entirely foreign to the Chaetomia, and are the fruiting bodies most probably of a Cunninghamella. The small number of perithecia which could be found still clothed with hairs were typical in every way of Ch. globosum Kze.

In I884 Bommer and Rousseau (8, p. 207) published a new variety to $C h$. Kunzeanum Zopf under the name fimicola. These authors compared their variety with $C h$. chartarum, Ch. globosum, and Ch. Fieberi, and while type material is not at hand, it would seem from their description that the variety could well be included under Ch. globosum Kze. Marchal (55), referring to this variety as forma fimicola, called attention to the fact that the spores, measuring $14 \times 8.6 \mu$, were a little larger than in the species above mentioned and that this plant could not be 
identified with them as Zopf had listed them in his monograph. The larger size of the spores, however, seems an insufficient reason for setting apart this variety, for in Ch. Kunzeanum Zopf, the spores are found to vary in size from $9 \mu$ to $13 \mu$ in length and from $8 \mu$ to $9.5 \mu$ in width.

An examination has been made of mounts from original material which was described in 1892 by Ellis as Ch. olivaceum C. \& E., var. chartarum, and which had already been listed and distributed without description by Roumeguère, in Rev. Myc. II : I30 and Fung. Gall. No. 4930, in I889, as f. chartarum. The spores have been measured and found rather to correspond with the somewhat variable spores of Ch. globosum Kze. As to the fact that the color varied from nearly black to mouse color and even to greenish-yellow, it may be said that such variations may easily be found in one and the same culture, and may be attributed to a difference in age. It hardly seems advisable to set plants with such a variable and uncertain characteristic apart from the type species.

During the same year Beauverie published an account of his work with cultures of the conidial form which Saccardo (77) called Oospora crustacea. In the month of June Beauverie found perithecia in tube cultures of potato which dated from January, and which were very tightly closed with cotton and covered with caoutchouc, so that no communication between the media and the outside air was possible. The white carpet of conidial vegetation was found to be spotted with small dark green bodies which were recognized as Chaetomium, and to which the name Ch. oospora was given. At two different times the writer has found conditions similar to those to which Beauverie has called attention in connection with his work. Cultures which were supposed to have been pure and had apparently remained uncontaminated for a considerable period showed in both cases the organization of perithecia which have finally developed into plants typical of Ch. globosum. While the writer has never examined type material of Beauverie's form, he is led to believe from his own experience and from Beauverie's description, that Ch. oospora is identical with the above named species of Kunze. While only the original description and figures of $\mathrm{Ch}$. Elasticae 
published by Koorders (49) in 1907, have been available for study, the writer has concluded that this plant should be included under Ch. globosum Kze. In fact at the end of his diagnosis Koorders has stated that undoubtedly his species is related to Ch. Kunzeanum, which, as Zopf stated, has a very wide distribution on various substrata.

Bainier in his "Monograph of Chaetomium" (3) has treated the varied forms of $C h$. globosum Kze. as distinct species, and has listed and described them under the following names: $C h$. megalocarpum, Ch. setosum, Ch. spirilliferum, and Ch. undulatum. It is the opinion of the present writer that these should not be separated from the type form, since they prove to be extremely variable when grown in cultures.

In addition to the above mentioned forms it is possible that Ch. Douglasii, described by Schweinitz in 1834 , and Ch. Fieberi Cda., var. macropoda, described by Spegazzini in 1898 , should be listed here, but type specimens of these are not available and the description in both cases is of such a general nature that it is hardly possible to determine the identity of these forms. They will be found listed, therefore, among the doubtful species.

The above is as complete an account of the synonymy concerned with this species as the writer is able to give, and it may be well to state here that he has arrived at the above conclusions on!y after long experience in cultivating the variable forms of the species which have been gathered from nearly all parts of the world, and only after a thorough study of exsiccati and type specimens so far as they have been available.

From an examination of the above exsiccati it has been found that in several the specimens contain plants which belong to other species and in some cases at least to other genera. In the following only Ch. elatum Kze. could be found: Ch. chartarum Ehrb. in Micro.-Fung. Brit. No. 475; Ch. Fieberi Cda. in Fung. Gall. No. 6409; Ch. Fieberi Cda., var. chartarum Roum. in Fung. Gall. No. 5827 ; Ch. Kunzeanum Zopf in Myc. March. No. 3246, and Ch. olivaceum C. \&. E. in Myc. Univ. No. 1942. The specimen under the name Ch. chartarum Ehrb. in Fung. AustroAmericani, No. 193 contains plants of Ch. chartarum (Berk) Winter, or Ascotricha chartarum according to the nomenclature 
used in this paper. That under the same name in N. A. F. No. I54I consists in part of Ch. globosum Kze., of Ch. elatum Kze., and of Ch. cochliodes Pall. No plants could be obtained from Ch. chartarum Ehrb. in Fung. Brit. No. 328, while from specimens under the same name in Fung. Gall. No. I09o only Stachybotrys lobulata could be obtained. The specimen under the name Ch. Fieberi Cda. in Herb. Myc. No. I65 and Myc. Ital. No. I288 is in part Ch. globosum Kze., and in part Ch. elatum Kze. Only Ch. murorum Cda. could be obtained from mounts of Ch. Kunzeanum Zopf, in Fung. Gall. No. 4436, while the specimens under the name Ch. lanosum Peck, in Fung. Gall. No. 4437 consist for the most part of Chaetomidium fimeti (Fckl.) Zopf, with a considerable number of perithecia of Ch. elatum Kze. intermingled. Ch. olivaceum C. \& E. in Fung. Columb. No. 5I2 is found to consist partly of Ch. globosum Kze., of Ch. elatum Kze., and in part of Chaetomidium fimeti (Fckl.) Zopf.

2i. Chaetomium spirale Zopf, Nova Acta Leop. Carol. Akad. 42: 275. pl. I9, f. 2I-26. I88I

Chaetomium spirochaete Palliser, N. A. Flora 3: 6I. I9Io.

\section{Plate I2, Figs. $5^{-8}$}

Dark brown to black. Perithecia of medium size I50-300 $\mu$, globose or ovate with a bluntly pointed base, seated on dark olive-yellow to brown rhizoids. Lateral hairs long, graceful, nearly straight or slightly flexed, very gradually tapering toward the tip, septate throughout, at base $3-5.5 \mu$ in thickness, dark olive-brown, sometimes smooth but more frequently roughened by irregular hyaline bodies of varying size and shape, becoming smooth above and fading to a colorless or pale yellow tip. Terminal hairs sparsely septate, dark, rich olive-brown, roughened by minute spines and warts, slightly paler and somewhat less roughened near the tips, straight or only slightly bent below for $300-370 \mu$ of their length, $4-6 \mu$ in thickness at base, spirally coiled above with 6-I4 turns. "Asci club-shaped, with a short stalk, pars sporif. 34-43 $\mu$ long." Spores lemon-shaped, slightly apiculate at either end or irregularly oval or spherical, dark rich olive-yellow to olive-brown, $9 \times 7 \mu(6-12 \times 5.6-9)$, when seen edgewise, $5 \cdot 5^{-7} \mu$ broad.

The species above described is apparently not common, and has never appeared in any collections made by the writer. Type locality: near Berlin; on horse dung. 
Through the kindness of the New York Botanical Garden the writer has been enabled to examine type specimens of Ch. spirochaete which were collected on cotton roots at Ames, Iowa, by L. H. Pammel, and which were named Ch. spirochaete by Palliser in her monograph of the genus. These seem to be identical with Zopf's species. The envelope containing the type specimens bears the name Ch. bostrychodes Zopf, for which this material had previously been mistaken. On a slip of paper within the envelope, however, was written in the form of a note: "Spores Iо $\times 7 \mu$, dark brown, too large for bostrychodes although same shape." The large size and dark color of the spores are characteristics which easily separate this form from $C h$. bostrychodes Zopf, and identify it with Ch. spirale Zopf.

At first sight Ch. spirale Zopf might easily be confused with Ch. bostrychodes Zopf, which it so closely resembles so far as the hairs are concerned, but from which it differs markedly in spore characteristics. The characteristics of the asci are quoted from Zopf's original description.

22. Chaetomium aterrimum Ellis \& Everhart; Palliser, N. A. Flora 3: 62. I9Io

\section{Plate I2, FIGS. I-4}

Gray black to black. Perithecium of medium size, ovate or subglobose, $275 \times 200 \mu(190-300 \times 160-230)$, seated on oliveyellow or olive-brown rhizoids. Lateral hairs numerous, long, slender, graceful, straight or slightly flexed, septate, gradually tapering, minutely roughened throughout or only near the base, below olive-yellow or dark olive-brown, $4-5 \mu$ in thickness at base, above pale yellow or hyaline. Terminal hairs very rarely producing small abortive branches, opaque, olive-brown or black and roughened by minute spines throughout, irregularly septate, at base $5^{-6} \mu$ in thickness, at tip 8-I I $\mu$ in thickness, below straight or slightly flexed, above coiling Io-I 8 times (usually about I5) in a long, close, regular, cylindrical spiral, $45^{-60} \mu$ in diameter. Asci not visible. Spores olive-brown, lemon-shaped, slightly apiculate at either end, $7.5 \times 6.5 \mu(6.5-8 \times 6.4)$, when seen edgewise, compressed, $4.8 \mu$ broad.

This is an exceedingly rare form apparently known only from the type locality: Rockport, Kansas; on damaged wheat in a stack, I89i (Bartholomew 448). 
Through the kindness of the New York Botanical Garden it has been possible to examine type specimens of this interesting species. The large diameter of the terminal hairs and their exceedingly long and regular cylindrical spiral distinguish this from all other species.

23. Сhaetomium bostrychodes Zopf, Abh. Bot. Ver. Prov. Brandenburg 19: 173; I877. Nova Acta Acad. Leop.-Carol. $42: 277 \cdot p l .20, f .14-26 . \quad$ I $88 \mathrm{I}$

Chaetomium caninum Ellis \& Everhart, Jour. Myc. 4: 79. 1888. Chaetomium formosum Bainier, Bull. Soc. Myc. France 25: 215. pl. 2o, f. 6-9. I910.

Chaetomium formosum, var. neglectum Bainier, l. c. 25: 217. pl. I $8, f$. 8. I9го.

Chaetomium formosum, var. ovatum, Bainier l. c. 25: 216. pl. 20, f. I-5. I910.

\section{Plate I3, Figs. I-I I}

Steel gray. Perithecia of medium size, extremely variable in shape, broadly ovate, globose or nearly cylindrical, generally with a bluntly pointed base, $340 \times 220 \mu(\mathrm{I} 68-350 \times$ I3I-230), frequently provided with black, straight or re-curved cirrhi. Lateral hairs not numerous, encrusted, clearly and evenly septate, tapering, at base dark olive-brown and about $3.8 \mu$ in thickness, at tips pale yellow or hyaline, frequently collapsed. Terminal hairs encrusted and roughened with spine-like projections throughout, at base straight or very slightly flexed, dark olive-brown to black and about $4 \mu$ in thickness, slightly less colored at tips, always more or less spirally coiled but in this respect extremely varied. In the type either regularly coiled with seldom more than 5-7 convolutions which diminish almost imperceptibly in diameter toward the extremity, or irregularly coiled with two or three loose, irregular convolutions; in either case irregularly septate, producing along the convolutions one or more branches which in turn are septate and spirally coiled. Asci short, stout, clubshaped, 8-spored, $50 \times$ I $2 \mu$, pars sporif. $24 \mu$. Spores when young greenish, hyaline, with granular contents, when mature pale with olive-brown tint, oval to nearly spherical, clearly or obscurely apiculate, or rounded at both ends, frequently with an elliptical, refractive area abreast of each end, a characteristic observed only in this species, $7.4 \times 6 \mu(6.4-8 \times 5.6-6.4)$, when seen edgewise, compressed, $4.8 \mu$ broad.

Exsiccati.-Fung. Europ. Edit. Nova, Series II, XXXiv, 3340; Myc. March. No. 43. 
An extremely common species having appeared in cultures of dung of many animals from nearly all parts of New England, Florida, Chili, Venezuela, and China (Chivers No. 2r). Reported also from many localities in middle western and western United States, and from England and Germany. Type locality,Berlin and Göttingen; on decaying animal and vegetable substances (carcasses, potatoes, and rabbit dung).

In I888 Ellis and Everhart (3I) gave the name Ch. caninum to material found on dog dung in Louisiana. Later, however, the same authors (32) listed this name as a synonym under $C h$. bostrychodes Zopf.

Ch. bostrychodes has proved to be a most variable species and before extensive cultures had been made the separation of the variable forms into distinct species seemed possible. A careful examination of plants grown under cultivation has been sufficient, however, to convince the writer that this should not be done, for there is no line which can be drawn between one variable form and another. While no material is available of Ch. formosum, Ch. formosum, var. neglectum and Ch. formosum, var. ovatum, all of which were described by Bainier in his monograph of Chaetomium, the writer is strongly of the opinion that they should be considered rather as variations of the type form.

The specimen in Fung. Europ. No. 3340 has been examined and found to be typical of Ch. bostrychodes Zopf.

24. Chaetomium quadrangulatum Chivers, Proc. Am. Acad. 48: 85. I9I2

Plate I 4 , Figs. I-8

Gray. Perithecia rather large and elongated, barrel-shaped, $403 \times 294 \mu(333-456 \times 243-350)$, frequently provided with one or more very long cirrhi, producing a mass of dark olive rhizoids near base. Lateral hairs numerous, slender, straight, regularly and distinctly septate, at the base dark olive to black, minutely roughened and about $7.5 \mu$ in thickness, in upper part pale yellow or hyaline, smooth. Terminal hairs of two types; $(a)$ unbranched, minutely roughened, below dark olive-brown to black, straight, septate, above coiling in the form of a spiral with 2-6 convolutions, near tips light olive-yellow or colorless, sparsely septate; (b) showing tendency to twist in spiral fashion near the middle of their length, or curved or sometimes nearly straight throughout, 
many with a single coil near the middle of their length, finely roughened throughout, below dark olive-brown to black, and about $7.5 \mu$ in thickness, clearly septate to near tips which are hyaline (along the hairs of this nature several branches may be produced, the branches partaking of the nature of the hairs). Asci club-shaped, 8-spored, $39 \times 9.7 \mu$, pars sporif. 2 I $\mu$. Spores when young greenish, hyaline with small refractive globules, when mature pale olive, when seen in face view four-sided and four-angled, either nearly square with equally rounded corners or with depressions in the four sides, in which latter case there are generally two acute angles at opposite ends which mark the length of the spore, while the angles at the sides are broad and obtuse, $7.3 \times 6.3 \mu(6.4-8 \times 5.6-6.4)$, when seen edgewise ovate, $3-4 \mu$ broad.

Cultivated on dung from Cambridge, Massachusetts (Chivers No. 29). Appearing also on dung from Chile and from Little Swan Island, Gulf of Mexico.

This species may be easily identified by its spores, which when seen in face view are four-sided and four-angled, but when seen in profile are oval. Ch. quadrangulatum and Ch. trigonosporum are the only species known to the writer which possess spores with angles, the former having spores clearly quadrangular, the latter clearly triangular.

25. Chaetomium caprinum Bainier, Bull. Soc. Myc. France 25: 223. pl. 24. I9IO

Plate I3, FIGS. I 8-22

Steel gray. Perithecia large, tall, greatly elongated with greatest width just above the base, then narrowing with the upper portion cylindrical, $580 \times 215 \mu \quad(400-580 \times 200-228)$, seated on a subiculum of dark olive-brown to black rhizoids, with perithecium wall composed of cells greatly elongated in a plane parallel to the long axis of the perithecium, of ten provided with short, stout, black cirrhi. Lateral hairs rather numerous, tapering, septate, smooth or minutely roughened with spines, some uncuticularized, colorless and easily collapsible, others stouter, at base dark olive-brown and about $6.6 \mu$ in thickness, fading and tapering gradually to a colorless, collapsed tip. Terminal hairs almost entirely obscured at maturity by the mass of spores, smooth or minutely roughened with spines, irregularly and remotely septate, at base straight or flexed, dark olive-brown, about $7.5 \mu$ in thickness, fading toward tip, coiling above irregularly or in the form 
of a spiral, producing here and there along their convolutions short branches which in turn are septate, tapering and irregularly coiled. Asci club-shaped, 8-spored, $50 \times$ 10 $\mu$, pars sporif. $24 \mu$. Spores when young greenish, hyaline, filled with granular contents, when mature pale with slight olive tint, ovate to globose, sometimes minutely apiculate at both ends, $6.6 \times 5$.I $\mu$ (5.6-8.I $\times 4.8-5.6)$, when seen edgewise, compressed, $4.5 \mu$ broad.

On muskrat dung, Massachusetts; rat dung, Liberia, Herb. R. Thaxter; on dog dung, Connecticut (Chivers No. 20). Type locality: Paris(?); on goat and sheep dung.

It is possible that this species may be identical with $C h$. rostratum, described by Spegazzini in 1899 , but type specimens of his form are not available and it is impossible to decide with certainty from a study of the original description. Spegazzini's species has been listed, therefore, among the doubtful forms.

The species may be easily distinguished from $C h$. bostrychodes Zopf, which it most nearly resembles, by the extreme length of the perithecium, a characteristic which has proved constant through cultures including many generations.

\section{Chaetomium cochliodes Palliser, N. A. Flora 3: 6r. igio} Chaetomium flexuosum Palliser, N. A. Flora 3: 6r. I9ı.

\section{Plate I5, Figs. I-8}

Grayish-green, brilliant green, often losing color and becoming dark brown in dry herbarium material. Perithecia globose or subglobose with bluntly pointed base, $340 \times 295 \mu$ (318-360 $\times$ 273-310), forming black cirrhi in comparatively few cases only, producing a heavy mass of stout, dark olive-brown to black rhizoids which anchor the plants firmly to the substratum. Lateral hairs numerous, irregularly and sparsely septate, evenly roughened with extremely fine projections, some hairs rather stout, tapering, straight or evenly bent, at base about $5.3 \mu$ in thickness and dark olive-brown to black, above faded yellow, at tips frequently hyaline, other hairs loosely and irregularly twisted through their entire length, still others straight for a long distance, then spirally twisted. Terminal hairs very numerous and finally interwoven forming a thick, massive, shaggy head, always of two types; (a) thick, stout, projecting beyond the dense portion of the head, then becoming spirally coiled with about three or four convolutions, dark olive-brown, almost black below, fading above to light yellow or becoming colorless, evenly roughened throughout and without visible septa, at base about $7.5 \mu$ in 
thickness; $(b)$ slender, sometimes coiling in spirals, at other times irregularly twisted or undulate, medium olive to light yellow, lighter than those of type $(a)$, about $2.5 \mu$ in thickness at base. Asci irregularly club-shaped, 8 -spored, $88 \times$ I I $\mu$, pars sporif. $32 \mu$. Spores when young colorless, filled with refractive globules, when mature dark, rich olive-brown, lemon-shaped, apiculate at both ends, $9.5 \times 7.2 \mu(8.9-9.7 \times 6.4-8.4)$, when seen edgewise, compressed, $6.4 \mu$ broad.

Exsiccati.-Sub Ch. chartarum Ehrb.: N. A. F. I54I (in part).

On paper, straw, dung and leaves from many localities in New England. Also from middle western and southern United States, Java and Ceylon (Chivers No. 24). Type locality: Newfield, New Jersey; on paper (Ellis \& Everhart in N. A. F. No. I54I in part.)

Type specimens of the plant which Palliser in her monograph named $C h$. cochliodes and which are to be found in North American Fungi, No. I54I, under the name Ch. chartarum Ehrb. have been examined by the writer. It has been discovered for the first time by Palliser that this is a separate species to be set apart from $\mathrm{Ch}$. globosum Kze. It has been found frequently and, while its color as well as its general appearance at maturity may resemble $\mathrm{Ch}$. globosum Kze., careful study in cultures and during its earlier development furnishes sufficient evidence that it is to be reckoned with as a distinct species.

It seems hardly advisable to consider Ch. flexuosum, which was described by Palliser (65) in I9I0, a distinct species, but rather as a dilapidated condition of $C h$. cochliodes. The type specimens of this plant have been found to be in extremely poor condition. Through the kindness of Professor Kauffman and Dr. F. J. Seaver, the writer has been provided with sufficient material of the original gathering to enable him to arrive at the conclusion that the plant is none other than $C h$. cochliodes. Mounts of such material show, in the first place, that the plants are old and much weather-beaten. In most cases perithecia bear only rhizoidal hairs and stumps of the lateral and terminal hairs. One perithecium which was most perfect of all available shows its top to be covered with a large number of hairs which are stout, straight for a considerable distance, then loosely spirally coiled once or twice, at which point by far the largest number are 
broken. There seems to be every reason to believe that the hairs, had not so many been broken away by disintegration, are sufficient in number and suitable in characteristics to make up a head typical of Ch. cochliodes. The spores are also typical of that species.

Ch. cochliodes Palliser may be confused, especially when fully developed, with Ch. globosum Kze. It may be most easily distinguished, in its earlier life history, when the terminal hairs show clearly two types; the one straight, stout below, spirally coiled above; the other much more slender, loosely spirally coiled, twisted or only wavy, and entangling the stouter hairs.

\section{Chaetomium angustum sp. nov.}

Plate I6, Figs. 6-I2

Rich olive-green. Perithecia rather large, subglobose, with a bluntly pointed base, $304 \times 266 \mu(280-300 \times 240-290)$, forming cirrhi in comparatively few cases, producing a dense mass of dark olive-brown to black, undulate rhizoids. Lateral hairs very numerous, obscurely and sparsely septate, either stout, tapering, dark, olive-brown to black at base and about $6.6 \mu$ in thickness, fading above and becoming pale yellow, hyaline at tips, or slender, olive-yellow and flexed or irregularly, spirally twisted. Terminal hairs of three types: $(a)$ straight, long, tapering, dark olive-brown to black at base, light yellow to hyaline at tips, minutely roughened throughout with spines, obscurely septate or continuous, at base about $6.7 \mu$ in thickness; (b) slender, graceful, below straight or only slightly flexed and about $3.8 \mu$ in thickness, in upper portions coiling spirally with about $5^{-7}$ convolutions which are comparatively small in diameter, minutely roughened throughout, sparingly septate or continuous, at base dark olive-brown, fading toward the tips; (c) stout, coarse, roughened throughout, sparingly and obscurely septate, below straight, very dark olive-brown, at base about $7.5 \mu$ in thickness, above spirally coiled at first regularly coiled with $2-3$ convolutions, often becoming irregular and retaining only a single coil near the middle of their length from which, frequently, one or two branches arise. Asci irregularly club-shaped, 8-spored, $50 \times 14 \mu$, pars sporif. $23 \mu$. Spores when young greenish, hyaline, filled with irregular, refractive globules, when mature dark olive-brown, lemon-shaped, apiculate or umbonate, 10 $\times 8 \mu$ (9.7-10.5 $\times 7.3^{-}$ 8.I).

On culture of bat dung from Porto Rico (Chivers No. 25).

This species may be confused with Ch. cochliodes Palliser, on 
the one hand, and on the other hand with Ch. globosum Kze. From the former it differs in its straight terminal hairs, and in the fact that the terminal hairs never form a dense head. From the latter it differs also in its loose head of terminal hairs and in the fact that it possesses straight and stout, coarse, spirally coiled terminal hairs.

28. Chaetomium torulosum Bainier, Bull. Soc. Myc. France

$$
\begin{aligned}
& \text { 25: 224. pl. 23. I9IO } \\
& \text { Plate i6, Figs. I-5 }
\end{aligned}
$$

Golden-yellow. Perithecia of medium size, rather tall and elongated, vase-shaped, $355 \times 170 \mu(290-140 \times 150-187)$, frequently provided with short, stout, blue-black cirrhi. Lateral hairs numerous, varying in length, delicate, smooth, generally slightly curved or bent, clearly and regularly septate, near base dark olive, about $3.7 \mu$ in thickness, gradually fading above to yellow and ending in extremely slender, colorless, crumpled tips. Terminal hairs almost entirely concealed at maturity by the spore mass, long, slender, graceful, irregularly flexed, clearly and regularly septate to near the tips, conspicuously constricted at, and inflated between, the septa, dark olive-brown at base, about $3.8 \mu$ in thickness, very gradually fading and tapering for a long distance, terminating in a long colorless, refractive thread. Asci irregularly club-shaped, 8 -spored, $40 \times$ Io $\mu$, pars sporif. I $8 \mu$. Spores when young hyaline, filled with refractive globules, when mature very dark, rich olive-brown, lemon-shaped, apiculate, extremely variable in size, $9 \times 7.6 \mu(7.3-\mathrm{II} .3 \times 6.4-9)$, when seen edgewise, compressed, $4.5 \mu$ broad.

In cultures of old paper, muskrat, rat and rabbit dung from various localities in New England (Chivers No. 5). Type locality: Paris(?).

This species may be easily distinguished from Ch. ampullare, which it most nearly resembles, by the fact that the perithecia are less elongated, the lateral hairs much more numerous and shorter, and the terminal hairs less rigid and conspicuously constricted at the septa.

\section{Species Dubiae}

Unfortunately it has been impossible to identify certain forms which have been described from time to time, on account of the fact that their characteristics are not given in sufficient detail 
and no type material is at hand for examination. Since the present writer cannot speak with certainty regarding these, it has seemed best to list them as doubtful species.

In I834 Schweinitz (9I) described Ch. Douglasii as a very remarkable fungus allied to Sphaeria comata. In the herbarium of Curtis, now at Harvard University, there is a reference to this species and a very simple figure of it, but no specimen. Saccardo, in the Sylloge (p. 229), has listed this as a doubtful form. From a study of the very general description it seems possible that this may be identical with Ch. globosum of Kunze.

Ch. lanatum, which was described by Quelèt (70) in I876 and to which reference has already been made, may possibly be identical with Ch. globosum Kze. Quelèt's description is of a very general nature, but his figures though simple show sinuous hairs like those of Ch. globosum, and spores similar in shape to those of the same species.

Little is known of the form which Spegazzini (94) found on dog dung in Italy, and which he described in 1878 as Ch. stercoreum. In the following year Saccardo (74) figured this and in I894 Cavara reported it, but without further comment.

In I88I Spegazzini (95) contributed a new form under the name Ch. microsporum. While no type specimens of this species are at hand it would seem that it might be identical with $C h$. globosum Kze., with the exception that the spores, which measure $5^{-6.5} \times 4^{-5} \mu$, are smaller than in Kunze's species.

It is impossible to determine from Karsten's (48) description, even though reasonably complete, the exact nature of the species which he described in I 888 under the name Ch. humanum, and so far as can be learned no author has since found or identified it.

The writer has little knowledge of the form which Starbäck (97) described in I889 as Ch. discolor, and no specimens of the original material are at hand. It would seem, however, from a study of the description and diagrammatic figures, that with the exception of the smaller size of the spores the plant in question might be Ch. globosum Kze.

The original description and two general figures of $C h$. varium described by Delacroix (25) in I 897 recall the characteristics of Ch. globosum Kze., but on the other hand figure 4 represents the 
type of branching which is found in Ch. elatum Kze. The spores as figured are equally characteristic of either species. In a footnote Delacroix stated that the plant was allied to Ch. lanosum Peck, and to Ch. comatum (Tode) Fr., but such a condition could hardly be possible since those species differ so widely.

Reference has already been made to the possible identity of Ch. Fieberi var. macropoda, described by Spegazzini (96, p. 250) in I898, and Ch. globosum Kze. Saccardo (85) redescribed this variety giving a much clearer diagnosis, and here again there is marked correspondence with Kunze's species. The only variation seems to lie in the spores which, as described by Saccardo, are slightly narrower than those of Ch. globosum. Since original specimens are not at hand it is impossible to come to a satisfactory conclusion regarding this variety.

It has already been pointed out that Ch. rostratum, published by Spegazzini (96) in I899, may possibly be identical with $C h$. caprinum Bainier, but since Spegazzini's description is not entirely clear, and no type material is at hand, it is impossible to decide the matter with certainty. This species has been reported by A. P. Morgan (62), who found it on rabbit dung at Preston, Ohio, and who kindly forwarded a specimen of his collection to the present writer. The perithecia obtainable from the specimens were very much broken, however, and only their most general characteristics could be made out.

\section{Species Excludendae}

As a result of a thorough examination of the literature concerning described species of Chaetomium, and notes published in connection with exsiccati, a considerable number of names have been found which should be excluded from further use. In some cases the plants to which the names were originally applied have apparently never been described, and there is every reason to believe that their characteristics will never be clearly understood. In other cases the published account is so brief and inadequate that it is impossible to arrive at a satisfactory conclusion regarding the form in question, while the descriptions of several other species indicate clearly that they are not Chaetomia. The following list includes all names whose further use should be discontinued for the reasons above mentioned. 
In I8I 8 Ehrenberg $(28, p p$. I 5,27$)$ contributed a new species, Ch. gelatinosum, which, according to Zopf ( 113 , p. 204), is either an undeveloped condition of some other Chaetomium, or more probably a Myxotrichum, and which is placed by Saccardo (79) among his doubtful species. The original description, containing only a few of the most general statements, and with no accompanying figures, is entirely inadequate.

Fries (38) in describing a new species in 1829 under the name Ch. pusillum, overlooked one of the most salient characteristics of the genus pointed out by Kunze, namely,- the presence of an ostiole. This plant, possessing a minute, spherical, closed perithecium, with very short, stiff, opaque, bristle-like hairs, and producing spores which are at least one-septate, could hardly be classified as a Chaetomium. The same form has been observed by many authors since Fries's time, and has been given names as follows: Acanthostigma Chaetomium Auersw. (I); Caelosphaeria exilis (Alb. et Schw.) Sacc. (79); Niesslia Chaetomium (Cda.) Auersw. (I); Niesslia exilis (Alb. \& Schw.) Wint. (IIo); Niesslia pusilla (Fries) Schroeter (89); Nitschkia exilis (Alb. \& Schw.) Fckl. (42, p. 165); Peziza aterima Lasch; Sphaeria Chaetomium Cda. (2I); Sphaeria exilis Alb. \& Schw. (2, p. 44); Sphaeria exosporioides Desm. (26, No.-126); Venturia Chaetomium (Cda.) Ces. \& DeNot. (I3). The present writer has seen authentic specimens of Ch. pusillum, which were distributed by Fries in the Scleromyceti Sueciae XXVIII No. 272, and has found them to consist of small, black, naked pustules, not in the least resembling Chaetomia, scattered over the surface of the pine needles. Specimens under the same name and with the same characteristics have been distributed by Rehm in Ascomyceten No. I762.

In I 833 Wallroth published, in the Flora Cryptogamica (I09), eight new species which must be placed in the group of excluded names. They are as follows: Ch. Alchemillae, Ch. circinans, Ch. coccodes, Ch. depressum, Ch. epiphyllum, Ch. oxysporium, Ch. Potentillae, and Ch. strigosum.

Wallroth's original description of Ch. Alchemillae (I09, p. 873) is incomplete and leaves one uncertain regarding the exact nature of the form. That part of the description which is clear, however, would seem to indicate that the plant was a Ven- 
turia. Saccardo $(\mathbf{7 9}, 84)$ has recorded it under the name Venturia Alchemillae (Grev.) B. \& Br., while other authors have given names as follows: Asteroma Alchemillae Grev. $(37,44)$; Coleroa Alchemillae (Grev.) Wint. (I Io, p. 199); Dothidea Alchemillae Rabh.; Dothidea ceramioides Duby (27); Stigmatea Alchemillae Fr. (39, p. 423).

The plant to which Wallroth (I09, p. 266) gave the name $C h$. circinans is clearly not a Chaetomium. Saccardo $(75,79)$ has given to this form the name Venturia Kunzei, while other authors have applied the following names: Coleroa Chaetomium Rabh. (7I, No. 1456); Dothidea Chaetomium Kze. (5I); Stigmatea Chaetomium (Kze.) Fr. (39, p. 422).

The original description of Ch. coccodes, as given by Wallroth (109, p. 265), is very inadequate and it seems impossible to arrive at any satisfactory conclusion regarding it. Zopf (II3, p. 205) has stated without further explanation that it probably represents a Chaetomium, but is rather to be considered as a slightly developed stage probably of Ch. crispatum Fckl.

Regarding Ch. depressum of Wallroth (Io9, p. 266) it may be said that the original description is hardly that of a Chaetomium, but rather of an Excipula, since the perithecia are described as depressed-globose, sometimes oval, rough at the base, whence arise short, rigid, black hairs, exposing at the apex, where they are wide open, a disc of sporophores.

The original diagnosis of Ch. epiphyllum Kze. appeared among the species of Wallroth (Io9, p. 265) mentioned above, as a note rather than as a description. The name was used by Kunze in connection with specimens which he enclosed in a letter to Wallroth, but so far as can be learned the species has never been described. Specimens of this species distributed in Klotzsch. Herb. Myc. No. 1347 are found to consist of minute, smooth, black pustules.

Ch.oxysporium Wallr. (I09, p. 242) is merely mentioned by Wallroth in a description of a plant which he called Fusarium Chaetomium. It is a name which he himself had privately used for this form at an earlier date, but which he had never published.

The original description of Ch. Potentillae Wallr. (I09, p. 266), while of a brief and general nature, would hardly indicate a true 
Chaetomium. The perithecia were described as minute, black, with short, rigid hairs. Saccardo (79, p. 594) has listed this form under the name Venturia Potentillae (Fr.) Cke. (18). Other authors have placed it under the following names: Coleroa Potentillae (Fr.) Wint. (I Iо, p. I99); Dothidea Potentillae Fr. (37, p. 563); Stigmatea Potentillae Fr. (39, p. 422).

The very brief diagniosis of Ch. strigosum Wallr. (Io9, p. 265) is vague and insufficient, and unaccompanied by figures. Rabenhorst (7I, No. I309) has called this Ceuthospora phaeocomes.

Schweinitz (9I, p. 265) in I834 added the new name $C h$. Typhae to the genus, but the original description is scarcely more than a note. Type specimens from the Curtis herbarium, now at Harvard University, have been examined by the writer, but no material could be found on the stalks of the Typha. Considering the meagre description, there seems to be little reason for the continued use of this name or of the name Ch. Typhinum, which Schweinitz (9I, p. 3IO) later used for this species.

In I 845 Léveillé (52) published diagnoses of two supposedly new forms; Ch. Cumingii, which he found on fallen leaves near Manila, and Ch. viride, on fallen grasses in Paraguay. The diagnoses, unaccompanied by figures of any kind, are brief and of such a general nature that one is unable to gain any satisfactory knowledge regarding the real nature of the plants in question. It would seem that the use of both names may well be discontinued.

The description of Ch. hispidum, published by Fries (39, p. 405) in 1849 , is brief, calling attention only to the most general characteristics and to the hemispherical shape of the perithecium. No measurements of structures are given and it is impossible to arrive at a satisfactory conclusion regarding his material. The fact that the asci are four-spored would, in any case, exclude this species from Chaetomium.

In $185 \mathrm{I}$ Bonorden (9) described Ch. ciliatum and Rabenhorst published in the Bot. Zeitung (9: 453) a description of Ch. Braunii. In the same year Preuss (69) described Ch. concinnatum and $C h$. tomentosum, and in 1852 added still another name, Ch. signatum.

It may be seen from a study of Bonorden's description that the 
plants which he called $\mathrm{Ch}$. ciliatum are not Chaetomia, since the spores are cylindrical and provided at both ends with delicate cilia. Saccardo in the Sylloge Fungorum (3: 684) has given this plant a place under the name Dinemasporium ciliatum (Bon.).

Sections of the authentic material of Ch. Braunii Rabh., in Klotzsch. Herb. Myc. No. I554, show the fruiting bodies to be stromatic, cellular, passing far down below the surface of the host tissue, black and coriaceous, covered with short, black, spine-like hairs.

The three species, Ch. concinnatum, Ch. tomentosum, and Ch. signatum, are described only in a most general way without measurements or illustrations. Rabenhorst, in Linnaea (24: I44), has questioned whether Ch. tomentosum is sufficiently different from Ch. pannosum Wallr., and has stated that in his specimen the hairs are soft, not rigid. A study of Rabenhorst's Ch. tomentosum in Klotzsch. Herb. Myc. No. I 856 shows his plants to be $C h$. murorum Cda. No author, with the exception of Rabenhorst, has ever recorded the re-appearance of these forms and it would seem that the use of these names could well be discontinued.

In I 853 Strauss (99) published a diagnosis of what he considered a new species of Chaetomium under the name $C h$. nivale, and Montagne (6I) in I 856 added the name Ch. raripilum. The original description of $\mathrm{Ch}$. nivale, together with the figures which Strauss published in connection with it, furnish sufficient evidence that he was dealing with a genus other than Chaetomium. This plant has been listed by Saccardo (8o, p. 855) under the name Acanthostigma nivale (Str.). It is also evident from a study of Montagne's description that his plant is not a species of our genus. It is given a place by Saccardo in the third volume of the Sylloge (p. 322), under the name Chaetomella raripila (Mont.).

The description and simple figure of $\mathrm{Ch}$. fimeti, published by Fuckel (40, p. 49I) in I86I, are those of the plant which Zopf (II3, p. 280) described and figured under the name Chaetomidium fimeti, and which was still later described and figured by Bainier (3, p. 192) under the same name. Exsiccati specimens of this form are to be found in Rehm Ascom. No. 991, and Fung. Sax. No. 370 . 
It has been possible to study type specimens in Fung. Rhenani No. I572, of Ch. paucisetum, which was named by Fuckel (4I) in I 866. The perithecia have been found to be globose, closed, black, firmly adnate to the surface of the substratum, and naked or bearing only a few short, scattered, slender, spine-like hairs. In Die Pilze Deutschlands (IIo, p. 65) this form is given the name Chaetomella atra (Fclk1.).

In I 873 Berkeley and Broome (7) described Ch. glabrum and Ch. rufulum. The figures and descriptions of the first named species assure one that the plant is not a Chaetomium. It has been described by Cooke (I9) as Orbicula perichaenoides, and by Saccardo as Anixia perichaenoides (79, p. 35). So far as Ch. rufulum is concerned there is no indication, either in the description or the figures, of the presence of perithecial hairs. The asci and the rough, spherical spores are not typical of Chaetomium.

Through the kindness of Dr. Saccardo it has become possible to examine type specimens of Ch. calvescens (76), described by that author in $\mathbf{I} 878$. The specimens, however, are in such a condition that it is impossible to identify the plant in question with a great degree of accuracy. Only in one perithecium of the many which were mounted have any hairs been found, and in that case they are few and rather stiff and spine-like. In one perithecium the remains of a neck like that of Melanospora appears. The honey-yellow color of the apparently mature spores would indicate that the form is not a Chaetomium. In I 882, it was listed by its author (79, p. 227) under "Species Desciscentes."

Karsten (47) in I88I described a plant under the name $C h$. fimisedum which produced many spores in the ascus. No species typical of Chaetomium have been found to contain more or less than eight spores in their asci, and it seems reasonable to conclude that forms with a varying number of spores should be listed in another genus.

In I 882 Rehm (73) added the new name Ch. Polypori to the genus, and while authentic specimens are not at hand the original description indicates that these plants are not Chaetomia since the perithecia are minute, and clothed with very short, acute 
setae. The asci are cylindrical and contain subrotund or spherical spores arranged in a single row, and filiform paraphyses are produced among the asci.

During the following year I883, Roumeguère and Patouillard, in Rev. Myc. (5: 29), applied the name Therryana to a variety of Ch. atrum Link. A study of the original description and the accompanying figures together with an examination of authentic specimens in Fung. Gall. No. 2496, are sufficient to convince the writer that this variety has nothing in common with Ch. atrum but is identical with Chaetomidium fimeti (Fckl.) Zopf. During the same year Therry (I02) made mention of $C h$. exile, and whether he used this name by mistake or whether he purposely used it for a species which he intended to describe later, is uncertain. In either case it would seem advisable to exclude this, since, so far as can be learned, no reference has since been made to it, and no description has been published.

In I888 Roumeguère gave to a plant in Fung. Gall. No. 4438, the name Ch. globosum Kze., f. chartarum. The variety was not described, however, and so far as can be learned no mention or description has since appeared. From a study of mounted material from the authentic specimens, this plant is found to be identical with Chaetomidium fimeti (Fckl.) Zopf.

In 1892 Dr. Cavara (I2) described under the name Ch. Montemartinii a form which has characteristics similar to those of Ch. Calvescens Sacc. In this case, however, mounts of the type material received from Dr. Saccardo, and also of authentic exsiccati specimens in Fung. Longob. No. 228, show more clearly the exact nature of the plant. The perithecia, naked or scantily clothed with a few very slender, short hairs, are globose, flattened at the base, while from the top extends a cylindrical, curved neck, $70-80 \mu$ in length. At the top of the neck an ostiole is located. In spite of several attempts to obtain asci none have been found. The honey-yellow spores which are produced in the perithecium and which in mass possess a decided orange tinge are poured from the ostiole in enormous numbers whenever pressure is brought to bear on the perithecium. From these observations it may be seen that this plant is not a Chaetomium. In 1894 Ellis and Everhart (34) described as new Ch. palli- 
$d u m$, and through the kindness of Mr. J. Dearness the study of this form from original material has been made possible. This plant seems to possess characteristics entirely in common with those of Melanospora, and ought therefore, as suggested by Palliser in the North American Flora $(65$, p. 64), to be listed in that genus. Ch. marchicum, described by Lindau (53) two years later, also possesses characteristics of a Melanospora. According to the original description and figures a mouth or ostiole is formed at the top of the perithecium and this is surrounded by a few stiff bristles. In this area the adjacent wall cells become somewhat elongated. Saccardo $(83$, p. 627) has given to this form the name Sphaeroderma marchicum.

In I 898 Ellis and Everhart (36) described as new Ch. Abietinum, and Hennings (46, pp. I53 and I54) described two new species using the names Chaetomium? importatum and Ch. laeliicola respectively.

Through the kindness of the New York Botanical Garden, plants from the original specimens of Ch. Abietinum E. \& E. have been placed at the disposal of the writer, and a detailed study of that species has been made. The conclusion has been reached that the plants in question cannot be included in our genus. In mounts of the type material the perithecia are black, opaque and somewhat coriaceous, firmly adnate to the substratum of wood upon which they are growing, lacking an ostiole, and very densely covered throughout with short, stout, spine-like hairs typical more of Coleroa or Venturia than of Chaetomium. According to the original description the species is allied to Ch. sphaerospermum E. \& E. The bristles, however, are not branched and the sporidia are rather larger and only slightly compressed. At first sight the spores are similar to those of Ch. sphaerospermum E. \& E. which in this paper has been listed as a synonym under Ascotricha chartarum Berk., but with more careful study one finds that the spores are only slightly compressed and lacking in a girdle.

A study of the two authentic specimens kindly sent by Dr. Lindau, to which Hennings gave the name Chaetomium? importatum and Ch. laeliicola respectively, is sufficient to convince one that neither of these plants can be regarded as a Chaetomium. The first named species appears as dark, chocolate- 
brown or black, irregular pustules, with here and there stiff, dark bristles near the margin of the pustules. It has little resemblance to a Chaetomium. Mounts of authentic specimens of $\mathrm{Ch}$. laeliicola, to which Saccardo $(85$, p. 429$)$ has later referred as Ch. laeliicolum, show the plants to be in the form of irregular pustules erupted through the epidermis of the host, from which arise stout, dark, septate hairs. Sections of the same material show the fruiting bodies to be sunk deeply below the surface of the tissue of the substratum on which they grow.

In 1900 Cocconi (I5) gave the name Ch. papillosum to a plant which he found on rotting wood in a field at Bologna, and which resembles a Magnusiella in certain of its characteristics, and Ch. murorum Cda. in others, yet differs from both in some respects. He described and figured this form as having a small, globose perithecium, perforated at the apex by an ostiole, and with hairs diverging in all directions. At the apex the perithecium was rather scantily supplied with abruptly incurved hairs. The asci were cylindrical, with their spores arranged in a single row. According to Cocconi experiments with cultures of this plant demonstrated on the one hand the formation of a pycnidial stage which produced two-celled spores, and on the other, the formation of branched conidiophores bearing spores in a clump at the tips of the branches.

In 1902 Massee and Salmon (59) published a diagnosis of $\mathrm{Ch}$. arachnoides. At first sight mounted specimens of this form, which were received from the Royal Botanic Gardens at Kew, may be easily mistaken for a Chaetomium, but with more careful examination characteristics appear which are sufficient to exclude it from this genus. At the top of the perithecium is a long neck resembling that of a Melanospora, and it is from the neck that the hairs arise which form at maturity a tangled mass, and which closely resemble the hairs of $\mathrm{Ch}$. murorum Cda. The spores at maturity are honey-yellow in color, a characteristic unusual for Chaetomium spores.

There are three scattered nomina nuda which have been found in literature unaccompanied by description or figures, and regarding which little is known. Material under the name of Ch. Bromelliae Schw. has been found in the Curtis herbarium, 
but no further mention or description has been published. The plants here included are evidently not Chaetomia, for they consist of spherical or elongated, black pustules, firmly attached to the substratum by a broad base. There are no hairs with the exception of a few bases of stout hyphae at the sides of the fruiting body. No spores could be obtained. The material in the Curtis herbarium which, according to a note, came from the herbarium of Schweinitz, and which undoubtedly represents authentic specimens, appears to be an Epicoccum.

In the Nomenclator Fungorum of Streinz (100, p. I83) is found the following: "Chaetomium Montagnei Brond. in litt. ad M." This manuscript name, apparently used by Brondeau in a letter to Montagne, seems never to have been published. In the reference quoted it is said to be identical with Ch. murorum Cda.

In the Curtis herbarium is to be found under No. 5978 the name Ch. subnudum B. \& C. Examination of material here contained, which must have been collected previous to 1872 , shows the fruiting bodies to be of the nature of pustules sunken in the tissues of the host, black and round or elongated. The spores are dark bronze and one-septate. It is evident that the material is not that of a Chaetomium and so far as can be learned no description has ever appeared.

\section{The Genus Ascotricha, Historical Review}

A description of the genus Ascotricha was first published by M. J. Berkeley in the Annals of Natural History (5, p. 257). The characteristics were there cited as follows: "Peridium thin, at length bursting, clothed with dark, sub-pellucid, even, obscurely jointed hairs; sporidia simple, contained in linear asci. Superficial, at length free or only supported by the investing thallus, black." In connection with his account of the genus, he gave a very full and complete description of a single species, As. chartarum, and illustrated the same with six figures. Only one other form similar to that published by Berkeley is known. This was first described by Ellis in 1890 , in the Proceedings of the Academy of Natural Sciences of Philadelphia, page 220, under the name Ch. pusillum.

In 187 I Cooke included this genus in the Handbook of British 
Fungi (2: 653), and defined it as follows: perithecium thin, free, astomate, seated on loose, branched, conidiophorous threads; sporangia linear, containing dark, elliptical sporidia.

These fungi should not be considered as true Chaetomia, but rather as species of an allied genus. The spherical perithecia, almost naked below and constricted at the top into a neck from which the terminal hairs arise, the curious stiff or whip-like ampullate hairs bearing large numbers of conidia, and the discshaped spores of one of the species, afford a sufficient basis for separating these forms from the genus Chaetomium. The earlier writers mentioned above were not aware that the perithecia of Ascotricha were provided with an ostiole, for Berkeley stated that the perithecia finally burst, and Cooke described them as astomous. Otherwise their descriptions are reasonably clear, and it therefore seems best to restore Berkeley's original name Ascotricha to his species, and to change the name of Ch. pusillum E. \& E. to Ascotricha pusilla.

\section{Characters of the Genus Ascotricha}

Perithecium when young subconical, dark green and translucent, when mature spherical or nearly so below, constricted above into a narrow and distinct neck, perforated by a central ostiole. Differentiated rhizoids lacking. Perithecial wall brittle, membranaceous. Lateral hairs colored and branched, varying in number, sometimes numerous, but at times almost wanting. Terminal hairs numerous, arising from the region of the neck, branched sympodially, and distinguished by the presence of clavate ampullae. Asci linear, cylindrical, 8-spored. Spores arranged in a single row in the ascus, simple, dark colored, discharged from the ostiole in a black cylindrical cirrhus.

\section{Key to the Species of Ascotricha}

Perithecial hairs and conidiophores slender, frequently gracefully flexed, sparingly branched. Conidia $5.5 \times$ $3.5 \mu$, smooth or nearly so. Ascospores ovate to eggshaped, $5.5 \times 4 \mu$.

I. As. pusilla (p. 220).

Perithecial hairs and conidiophores stout, profusely branched. Conidia $6 \times 5 \mu$, roughened by minute wart-like projections. Ascospores disc-shaped, $8 \times$ 
Ascotricha pusilla (Ellis \& Everhart) comb. nov.

Chaetomium pusillum Ellis \& Everhart, Proc. Acad. Nat. Sci. Phil. I890: 220. I890.

Chaetomium Ellisianum Saccardo \& Sydow, Syll. Fung. I4: 49 I. I 899.

\section{Plate I7, Figs. I3-2I}

Black. Perithecia small, globosé, the body somewhat broader than long, constricted above to form a distinct neck, I5I $\times$ I66 $\mu$ (I35-190 X I39-202), extruding long, black cirrhi, rather firmly adnate to the substratum and associated with numerous conidiophores. Lateral hairs when present sparsely scattered over the upper portion of the perithecium wall, slender, whip-like, more or less flexed or gracefully recurved to form a loop, tapering almost imperceptibly, evenly and remotely but obscurely septate, slightly swollen at the septa, near the base dark olive-brown to black and about $5.6 \mu$ in thickness, becoming pale olive at the tips, unbranched except very rarely when the short main axis produces an extremely long, whip-like outgrowth just above the origin of which the axile portion terminates in a club-shaped, hyaline ampulla. Terminal hairs arising in the region of the neck, extremely long, slender, whip-like, graceful, smooth and even, with the exception of slight angular swellings at the septa, flexed and often recurved forming a loop, septate but so dark below that the septa are nearly obscured, very dark olive to black and about $5.6 \mu$ in thickness at the base, almost imperceptibly tapering and fading toward the pale olive tip, unbranched except in rare cases, where branching takes place in the same manner as described above for the lateral hairs. Asci extremely delicate, linear, cylindrical, 8 -spored, $60 \times 6 \mu$, pars sporif. $43 \mu$. Spores monostichous, hyaline when young, when mature dark olive-brown, ovate, roughly egg-shaped, rounded at both ends, $5.6 \times 4.2 \mu\left(5.4-6 \times 3.5^{-4.5}\right)$, when seen edgewise, compressed, $3.2 \mu$ broad.

On barrels in cellar, Cambridge, Massachusetts, and Kittery Point, Maine, herb. R. Thaxter; on barrel hoops and packing boxes in cellar in Hanover, New Hampshire, and Amesbury, Massachusetts (Chivers No. 4I). Reported also by G. F. Atkinson from Alabama, growing on old paper.

Type locality: as Ch. pusillum E. \& E., Newfield, New Jersey; on basswood barrel bottom in cellar. Also Manhattan, Kansas; on an old churn in cellar (Kellerman I437).

The original material of this species was collected by Ellis 
at Newfield, New Jersey, and described by him as Chaetomium pusillum, in apparent ignorance of the fact that this combination had already been employed by Fries (38) for a different plant. For this reason a new name Ch. Ellisianum was proposed by Saccardo in the fourteenth volume of the Sylloge, p. 49I, but since for reasons already stated it has seemed best to recognize the genus Ascotricha, it becomes necessary to return to the original specific name used by Ellis, and to employ a new combination in designating this species.

Conidial growth precedes the development of the perithecia. The conidiophores when young are grayish-green to the naked eye, while at maturity they are black. Under magnification they appear long and slender, rather sparingly branched, at the base dark olive-brown to black and about $3.5 \mu$ in thickness, tapering and fading toward the tip, one to several times sympodially branched, the individual axes producing a lateral branch, above the point of origin of which the axis terminates in a clavate, hyaline ampulla. The lower branches in turn become verticillately branched, and bear large clusters of ovate to globose conidia which are hyaline when young, olive-brown at maturity, and measure $5.4 \times 3.6 \mu$, appearing smooth except with an immersion lens when a slight irregularity of the wall is apparent. In the mounts most favorable for study the threads of the mycelium are woven together into rope-like strands, along which conodiophores branch forth in large numbers and perithecia take their origin.

The species appears to be by no means rare in this country and may frequently be found often in company with other interesting forms growing on the bottom of barrels which have stood for some time in a damp situation, as for example on a cellar bottom. It may quickly be recognized by its jet black color and the characteristic mingling of perithecia and conidiophores with black masses of conidia and ascospores. This species may easily be distinguished from Ascotricha chartarum, which it most nearly resembles, by the following differences: the smaller perithecia, the extremely long, whip-like hairs which are frequently gracefully looped, but seldom branched, and the much smaller spores, which are egg-shaped instead of disc-shaped, and without a girdle. 
Ascotricha chartarum Berkeley, Ann. Nat. Hist. I : 257. pl. 7 , f. $8 . \quad \mathrm{I} 838$

Ascotricha Zopfi (Boul.) Peyronel, Ann. Myc. 12: 459-470. f. I-3. I9I4.

Chaetomium Berkeleyi Schroeter; Cohn, Krypt.-Fl. Schlesien 3: 284. I 894 .

Chaetomium chartarum Winter, Rabenhorst's Kryptogamen-Flora $\mathbf{I}^{2}$ : I57.f. 4-7. I 885. Not Chaetomium chartarum Ehrenberg, Sylv. Berol. 27. I8I8.

Chaetomium delicatulum Roumeguère, Rev. Myc. 7: 22. $\quad$ I 885 . Chaetomium sphaerospermum Cooke \& Ellis, Grevillea 8: I6. I879.

Chaetomium Zopfii Boulanger, Rev. Gén. Bot. 9: 25. pl. I-3. I 897. Dicyma ampullifera Boulanger, l. c. 9: I7. pl. I-3. I897.

Sporotrichum sp. Boulanger, l. c. 9: 17. pl. 2. 1897.

\section{Plate I7, FIGS. I-I 2}

Black. Perithecia rather small, globose or subglobose, constricted into a neck at the upper extremity, frequently flattened at the base, $192 \mu$ high $\times 198 \mu$ broad (I26-232 $\times$ I35-236), discharging black spore cirrhi many times longer than the perithecium, producing no differentiated rhizoids, but seated among and upon the stalks and branches of the conidiophores. Lateral hairs rather numerous, very variable in length but nearly always short, tapering near the tips only, branched and ampullate as are the terminal hairs, very dark olive-brown to black below, about $3.2 \mu$ in thickness near base, colorless and frequently septate near their tips. Terminal hairs extremely variable in length, straight, stiff, dark olive-brown to black except at the ampullae and extreme tips, remotely septate, frequently with an angular swelling at the septum, profusely and sympodially branched, each individual axis producing one or two lateral branches beyond the point of origin of which the axis terminates in a somewhat swollen, clubshaped colorless ampulla. Asci linear, cylindrical, 8-spored, $65 \times$ II $\mu$, pars sporif. $45 \mu$. Spores monostichous, when young pale olive with a greenish tinge, when mature dark olive-brown to black, regularly or irregularly circular in face view, lenticular, with girdle apparent when seen in profile, 8.I $\times 7.7 \mu(7.2-9 \times$ 7.2-8.I), when seen edgewise 4.5-5.4 $\mu$ broad.

Exsiccati.-Fung. Europ. Edit. nova, Series II, XXV, 2472; Micro-Fung. Brit. IV, 348, 355 and V, 474; Myc. Ital. I, 63; 
Myc. March. 69. Sub Ch. delicatulum Roum.: Fung. Gall. XXXII, 3 I 43 .

On cardboard, Cambridge, Massachusetts, Herb. R. Thaxter. On barrel bottoms from various localities in New England (Chivers No. 40). Reported also from different parts of the United States, South America, and Germany. Type locality: King's Cliffe, England; on a candle box.

The species was first observed in America by Ellis and was communicated to Cooke who described it as Ch. sphaerospermum, as indicated in the above synonymy. The writer has been able to examine specimens of the original material collected by Ellis, and has found it to be identical in every respect with Ascotricha chartarum.

Although this species appears to be so clearly characterized it has been repeatedly re-described, first in 1879 by Cooke and Ellis as above mentioned.

In I 885 Winter in his Pilze Deutschlands (I ro, p. I57) includes this species under the name Ch. chartarum, in apparent ignorance of the fact that this combination had already been used by Ehrenberg $(\mathbf{2 8}$, p. 27) for a wholly different plant, and in the same year Roumeguère added still another name to the list by re-describing this plant as Ch. delicatulum, since an examination of the description given by him, as well as a study of the authentic specimens distributed in Fung. Gall. No. 3143, leave no doubt as to its synonymy.

Schroeter (89) in I 894, being aware of the previous use of the name Ch. chartarum by Ehrenberg, but following Winter in his generic reference of the present species, completed the list of synonymy by adding yet another name $C h$. Berkeleyi.

In 1897 the form was redescribed under the new name $C h$. Zopfi $i$ by Boulanger (ro), to whom we owe a very complete account of its morphology and development. This author made excellent figures which place the identity of the plant which he had before him beyond question.

During the publication of this paper the writer has noted an article by Peyronel (68), in which he transfers this species from the genus Chaetomium to that of Ascotricha, still retaining Boulanger's specific name. As there seems to be no doubt that $C h$. 
Zopfii Boulanger is identical with Ascotricha chartarum, described by Berkeley in 1838 , it seems to the present writer more desirable to return to the use of the original name given by Berkeley than to continue the names given by more recent authors.

As in Ascotricha pusilla conidial growth precedes the formation of perithecia. The conidiophores to the naked eye are greenishgray when young and black at maturity. Under magnification they are dark olive-brown to black near their base and about $5 \mu$ in thickness, clearly but irregularly septate and very profusely and sympodially branched, each individual axis producing a single branch, or forking and prodúcing two symmetrical branches beyond the point of origin of which the axis terminates in a colorless, clavate ampulla. This may be several times repeated and the peripheral branches thus produced may form an irregular whorl, from which arise clusters of conidia which are roughly spherical, ovate or egg-shaped, roughened by minute warts, hyaline when young and olive-yellow or olive-brown when mature, $6.1 \times 5$.I $\mu$ $(5.4-7.2 \times 3.6-5.9)$.

This species is most often found on paper and cardboard, but like $A s$. pusilla, the only form with which it is in danger of being confused, it occurs frequently on barrels or boxes in cellars. A comparison shows at once that in the case of the former the perithecium is of greater average size, the hairs are much stiffer, straighter, and more profusely branched, the spores are larger and easily distinguished by the fact that they are circular in face view, but lenticular with a girdle at the margin, when seen in profile. 


\section{LITERATURE CITED}

In the following bibliography only the more important references have been included and no attempt has been made to list the numerous references which indicate simply the distribution of the various species.

\section{Auerswald, B.}

I. Synopsis Pyrenomycetum europaearum; Gonnerman \& Rabenhorst, Mycologia Europaea. 5, 6: [r]-[30]. 1869.

Albertini, J. B., \& Schweinitz, L. D. de.

2. Conspectus fungorum in Lusatiae superioris agro Niskiensi crescentium. Leipzig. I 805 .

\section{Bainier, G.}

3. Mycothèque de l'Ecole de Pharmacie XXX. Monographie des Chaetomidium et des Chaetomium. Bull. Soc. Myc. France 25: I9I-237. pl. 10-26. I910.

\section{Beauverie, J.}

4. Études sur le Polymorphisme des Champignons. Influence du milieu. Ann. Univ. Lyon, Nouv. Sér. I. 3: I-266. f. I-75. I 900.

B erkeley, M. J.

5. Notices of British Fungi. Ann. Nat. Hist. I: 257-264. pl. $7,8$. I 838 .

\section{Berkeley, M. J., \& Broome, C. E.}

6. Notices of British Fungi. Ann. and Mag. Nat. Hist. II. 7: 97I02; I76-I 89. pl. 5-7. I 85 I.

7. Notices of British Fungi. Ann. and Mag. Nat. Hist. IV. II: 339-349. pl. 7-IO. I 873 .

Bommer, E., \& Rousseau, M.

8. Florule mycologique des environs de Bruxelles. Bull. Soc. Bot. Belgique 23: I 5-365. I 884 .

\section{Bonorden, H. F.}

9. Handbuch der allgemeinen Mykologie. Stuttgart. I85I.

Boulanger, E.

Io. Sur une forme conidienne nouvelle dans le genre Chaetomium.

Rev. Gén. Bot. 9: I 7-26. pl. I-3. I 897.

Brondeau, L. de.

I I. Note sur le Chaetomium chartarum Ehrb. Bull. Soc. Bot. France

\section{Cavara, F.}

$$
\text { 4: 999-IO01. I } 857 \text {. }
$$

I2. Fungi Longobardiae exsiccati. Padua. I 892. 
Cesati, V., \& Notaris, G. de.

I3. Schema di classificazione degli Sferiacei italici aschigeri più o meno appertenenti al genere Sphaeria nell' antico significato attribuitogli da Persoon. Comment. Soc. Crittogam. Ital. I : I $77-240 . \quad 1863$.

Chivers, A. H.

I4. Preliminary diagnoses of new species of Chaetomium. Proc. Am. Acad. 48: 83-88. I9I2.

\section{Cocconi, G.}

I 5. Intorno ad una nuova specie di Chaetomium. Mem. R. Accad. Sci. Ist. Bologna 5: 683-688. pl. 8, f. I-g. 1900.

Cooke, M. C.

I6. British Fungi. Grevillea I: I74-180. I873.

17. Cocoa-Palm Fungi. Grevillea 5: I0I-103. 1877.

18. New British Fungi. Grevillea 6: 7 I-76. pl. 97, f. I6. 1877.

19. New British Fungi. Grevillea 8: I-I I. I 879.

20. Australian Fungi. Grevillea I2: 21. 1883.

Corda, A. C. J.

21. Icones Fungorum I. Prague. 1837.

22. Icones Fungorum 2. Prague. $\quad \mathrm{r} 838$.

23. Icones Fungorum 4. Prague. I 840.

Dangeard, P. A.

24. L'origine du Périthèce chez les Ascomycetes. Le Botaniste I0: 330-333. pl. 73 . 1907.

Delacroix, M. G.

25. Quelques espèces nouvelles. Bull. Soc. Myc. France I3: I I4I 27. $\mathrm{pl}$. IO, f. I-5. I 897 .

Desmazières, J. B. H. J.

26. Plantes cryptogames de France. Lille. 1853.

Duby, J. A.

27. Botanicon Gallicum 2. Paris. I830.

Ehrenberg, C. G.

28. Sylvae mycologicae berolinenses. Berlin. I8I8.

Eidam, E.

29. Zur Kenntniss der Entwicklung bei den Ascomyceten. Cohn's Beiträge 3:377-433. pl. 19-23. I 883 .

\section{Ellis, J. B., \& Everhart, B. M.}

30. New Species of Fungi. Jour. Myc. I: 90. 1885.

31. New Species of Fungi from various Localities. Jour. Myc. 4: 73-82. 1888.

32. The North American Pyrenomycetes. Newfield, New Jersey. I 892 . 
33. New Species of North American Fungi from various localities. Proc. Acad. Nat. Sci. Philadelphia I893: I28-I72. I 893.

34. New Species of Fungi from valious localities. Proc. Acad. Nat. Sci. Philadelphia 1894; 322-386. 1894 .

35. New species of Fungi from various localities. Am. Nat. 3I: 340. 1897 .

36. New species of Fungi from various localities. Bull. Torrey Club 25: 50I-5I4. I 898 .

\section{Fries, E.}

37. Systema Mycologicum 2. Lund. I823.

38. Systema Mycologicum 3. Greifswald. I829.

39. Summa vegetabilium Scandinaviae. Stockholm \& Leipzig. I 849 .

\section{Fuckel, I.}

40. Enumeratio Fungorum Nassoviae. Series I. Wiesbaden. I86I.

4I. Fungi rhenani. Hedwigia 5: 23-30. 1866.

42. Symbolae mycologicae. Wiesbaden. I 869.

\section{Greville, R. K.}

43. Scottish Cryptogamic Flora 4. Edinburgh. 1826.

44. Flora Edinensis. Edinburgh. 1824.

\section{Hansen, E. C.}

45. De danske Gjфdningssvampe (Fungi fimicoli danici). VidenHennings, $\mathbf{P}$. skabelige Meddelelser I876-78: 207-354. pl. 4-9. I 876 .

46. Die in den Gewächshäusern des Berliner botanischen Gartens beobachteten Pilze. Abh. Bot. Ver. Prov. Brandenburg 40: I09-176. pl. I, 2. I 898.

\section{Karsten, P. A.}

47. Enumeratio Fungorum et Myxomycetum in Lapponia Orientali aestate I86I lectae. Not. F. et Fl. Fenn. 8: I93-224. I 882 .

48. Symbolae ad Mycologiam Fennicam. XXVII, Meddel. Soc. F. et Fl. Fenn. I6: 33-36. I 888.

\section{Koorders, S. H.}

49. Botanische Untersuchungen über einige in Java vorkommende Pilze, besonders über Blätter bewohnende, parasitisch auftretende Arten. Verhand. d. K. Akad. v. Wetenschappen te Amsterdam (Tweede Sectie) I3 $3^{4}$ : I-264. pl. I-I2 +f. I-6I. 1907.

Kunze, G., \& Schmidt, J. K.

50. Mykologische Hefte I. Leipzig. I8I7.

5I. Deutschlands Schwämme. Leipzig. I8I8. 
Léveillé, M. J. H.

52. Champignons exotiques. Ann. Sci. Nat. Bot. III. 3: 38-70. I 845 .

Lindau, G.

53. Zwei neue deutsche Pilze. Hedwigia 35: 56-57. f. A-E. I 896. Link, H. F.

54. Linnaeus, C., Species Plantarum, Ed. 5, I. Berlin. I 824. Marchal, É.

55. Champignons coprophiles II. Décade d'espèces nouvelles pour la Belgique. Bull. Soc. Roy. Bot. Belgique $23^{2}: 59-6$ I. I 884.

56. Bommerella, nouveau genre des Pyrénomycètes. Bull. Soc. Roy. Bot. Belgique 24²: 164-I65. I 885 .

57. Bommerella, nouveau genre des Pyrénomycètes. Rev. Myc. 8: IOI. 1886.

58. Champignons coprophiles de Belgique. V. Note sur le Bommerella trigonospora. Bull. Soc. Roy. Bot. Belgique $28^{1}: 26 \mathrm{I}-$ 27I. pl. IO. I 889 .

Massee, G., \& Salmon, E. S.

59. Researches on Coprophilous Fungi. II. Ann. Bot. 16: 57-93. pl. 4, 5. 1902.

Mattirolo, O.

6o. Fungi; Savoia, Il Ruwenzori r. Milan. I909. Montagne, C.

6I. Septième centurie de plantes cellulaires nouvelles tant indigenes qu' exotiques. Ann. Sci. Nat. Bot. IV. 5:333-374. 1856. Morgan, A. P.

62. Pyrenomycetes scarcely known in North America. Jour. Myc. Oltmanns, F. I0: 226-228. 1904 .

63. Über die Entwickelung der Perithecien in der Gattung Chaeto. mium. Bot. Zeit. 45: 193-200, 209-218, 225-233, 249-254, 265-27I. I 887 .

Oudemans, C. A. J. A.

64. Aanwunsten voor de Flora Mycologica van Nederland IX en X. Nederlandisch Krinkundig Archief. II. 4: 267. pl. 6, f. I4. I 885 .

Palliser, H. L.

65. Chaetomiaceae. North American Flora 3: 59-64. I9Io.

Peck, C. H.

66. Report of the botanist. Rep. New York State Mus. Nat. Hist. 27: 73-1 16. pl. 1, 2. 1875 . 
67. Report of the botanist. Rep. New York State Mus. Nat. Hist. 49: 19-83. pl. 44-49. I 896.

Peyronel, B.

68. Osservazioni critiche e sperimentali su alcune specie del genere Dicyma Boul. e sui loro stati ascofori. Ann. Myc. 12: 459470. f. I-3. I9I4.

\section{Preuss, G. T.}

69. Uebersicht untersuchter Pilze, besonders aus der Umgegend von Quélet, L.

Hoyerswerda. Linnaea 24:99-I 53. I 85 I ; 25: 79-80. I 852.

70. Les Champignons du Jura et des Vosges. III. Mém. Soc d'Emulation de Montbeliard I875: I-I28. pl. I-4. 1876.

\section{Rabenhorst, L.}

7 I. Klotzschii herbarium vivum mycologicum. I85I.

\section{Reinke, J., \& Berthold, G.}

72. Die Zersetzung der Kartoffel duich Pilze. Untersuch. Bot. Lab. Göttingen I : 46-5I. pl. 4. I 879 .

\section{Rehm, H.}

73. Beiträge zur Ascomyceten-Flora der deutschen Alpen und Voralpen. Hedwigia 21: 97-I03, I I3-I 23. I 882.

\section{Saccardo, F. A.}

74. Fungi Italici autographice deliniati. Padua. I 877-I886.

75. Fungi Veneti novi vel critici. Series V. Nuovo Gior. Bot. Ital. 8: I6I-2II. I 876 .

76. Fungi novi ex herbario Prof. Doct. P. Magnus Berolinensis.

Michelia I: II7-I32. I 878 .

77. Fungi Veneti novi vel critici vel mycologiae Venetae addendi (adjectis nonnullis extra-venetis). Series XIII. Michelia 2: 528-563. I 882.

78. Fungi belgici lecti a cl. Dominis Elisa Bommer et Maria Rousseau. Misc. mycol. 2: 435-463. I 884 .

79. Sylloge Fungorum I. Padua. I 882.

80. Sylloge Fungorum 9. Padua. I 89 I.

8I. Sylloge Fungorum II. Padua. I 895 .

82. Sylloge Fungorum I2. Padua. I 897.

83. Sylloge Fungorum I4. Padua. I 899.

84. Sylloge Fungorum I5. Padua. I90I.

85. Sylloge Fungorum r6. Padua. I902.

86. Sylloge Fungorum 17. Padua. I904.

87. Sylloge Fungorum I9. Padua. I9I0.

88. Sylloge Fungorum 22. Padua. I9I3. 
Schroeter, J.

89. Pilze; F. Cohn, Kryptogamen-Flora von Schlesien 3. Breslau. - 1894 .

Schmitz, F.

90. Untersuchungen über die Zellkerne des Thallophyten. Sitzungsber. niederrhein. Ges. für Naturhist. und Heilkunde in Bonn 345-376. 1879 .

Schweinitz, L. D. von.

9I. Synopsis fungorum in America boreali media degentium. Trans. Amer. Phil. Soc. 4: I41-316. pl. 19. 1832.

Smith, A. L., \& Carleton, R.

92. The fungi of germinating farm seeds. Trans. Brit. Myc. Soc. I: I 82. pl. I 9. 1902 .

93. Fungi new to Britain. Trans. Brit. Myc. Soc. 2: 3I-40. I903.

\section{Spegazzini, C.}

94. Fungi coprophili Veneti. Michelia I: 222. $\quad$ I 878.

95. Fungi Argentini additis nonullis Brasiliensibus Montevidiensibusque Pug. 4: 98. No. II2. I88I.

96. Fungi Argenti novi v. critici. Anales del Mus. Nac. Buenos Aires 6: 8I-365. pl. 4, 5. I 899 .

\section{Starbäck, K.}

97. Anteckningar öfver några skandinaviska Pyrenomyceter. Bihang till Kongl. Svenska Vet.-Akad. Handl. 14 $^{3}$, No. 5: I-I 8. pl. I. 1889 .

Stewart, F. C.

98. Notes on various plant diseases. VI. Chaetomium contortum on barley seedlings. Bull. N. Y. Ag. Exp. Station Bull. I64: 22 I. 1899.

Strauss, F. F.

99. Pilze; J. Sturm, Deutschlands Flora 3. Nuremberg. I 853. Streinz, W. M.

I0o. Nomenclator Fungorum. Vienna. I 862.

Taubenhaus, J. J.

IоI. Chaetomium root rot. Delaware College Ag. Exp. Station, Bull. I06: 24-27. I914. [Illustrated.]

Therry, J. J.

I02. Contributions mycologiques. Ann. Soc. Bot. Lyon 10: 209. I 883.

Tode, H. J.

I03. Fungi Mecklenburgenses selecti 2. Lüneburg. I79I. 


\section{Van Tieghem, $\mathbf{P h}$.}

I04. Sur la développement du fruit des Chaetomium et la prétendue sexualité des Ascomycètes. Compt. Rend. 8I: IIIO-III3, I 875 .

I05. Sur le développement du fruit des Ascodesmis, genre nouveau de l'ordre des Ascomycètes. Bull. Soc. Bot. France 23: 27 I-279. I 876 .

I 06. Nouvelles observations sur le développement du périthèce des Chaetomium. Bull. Soc. Bot. France 23: 364-366. I876.

107. Sur le développement de quelques Ascomycètes, Bull. Soc. Bot.

France 24: 96-105. 1877 .

108. Remarque au sujet du développement des Chaetomium. Bull. Soc. Bot. France 29: 317-318. I882.

\section{Wallroth, F. G.}

I09. Flora cryptogamica Germaniae 2. Nuremberg. I833.

\section{Winter, G.}

I Io. Die Pilze Deutschlands, Oesterreichs und der Schweiz. II. Abtheilung. Rabenhorst's Kryptogamen-Flora $\mathbf{I}^{2}$. $\mathbf{1 8 8} 7$.

I I . Exotische Pilze. IV. Hedwigia 26: 6-I8. I 887.

\section{Zopf, W.}

I 12. Untersuchungen über Chaetomium. Abh. Bot. Ver. Prov. Brandenburg I9; I70-I73. I 877 .

I13. Zur Entwickelungsgeschichte der Ascomyceten. Chaetomium. Nova Acta Leop.-Carol. Akad. 42: I99-292. pl. I4-20. I88I.

\section{Zukal, H.}

I I4. Mykologische Untersuchungen. Anlage des Perithecium von Chaetomium crispatum Fuckel. Denkschr. Kaiser. Akad. Mathem.-Naturwiss. Klasse 5I: 2 I-36. pl. I-3. I 886. 


\section{EXSICCATI}

The writer's conclusions have for the most part been based on the exsiccati specimens in the Cryptogamic Herbarium at Harvard University.

Berkeley, M. J. British Fungi.

Cavara, F. Fungi Longobardiae Exsiccati.

Cooke, M. C. Fungi Britannici.

Curtis, M. A. Collection.

Desmazières, J. B. H. J. Plantes Cryptogames de France.

Ellis, J. B., \& Everhart, B. M. North American Fungi. Fungi Columbiani.

Fries, E. Scleromyceti Sueciae.

Fuckel, L. Fungi Rhenani.

Jaap, O. Fungi Selecti Exsiccati.

de Jaczewski, A. Fungi Rossiae Exsiccati.

Karsten, P. A. Fungi Fenniae Exsiccati.

Krieger, K. W. Fungi Saxonici.

Kunze, G., \& Schmidt, J. K. Deutschlands Schwämme.

Mougeot, J. B. \& J. A., \& Nestler, C. Stirpes Cryptogamae VogesoRhenanae.

Rabenhorst, L. Fungi Europaei.

Rabenhorst, L. Fungi Europaei. Klotzschii Herbarium vivum Mycologicum.

Rehm, H. Ascomyceten.

Rick, J. Fungi Austro-Americani.

Roumeguère, C. Selecti Gallici Exsiccati.

Saccardo, D. Mycotheca Italica.

Saccardo, P. A. Mycotheca Veneta.

de Thumen, F. Fungi Austriaci Exsiccati. Mycotheca Universalis. Vestergren, T. Micromycetes Rariores Selecti.

Vill, A. Fungi Bavarici Exsiccati.

Vize, J. E. Micro-Fungi Britannici.

Wartmann, B., \& Schenk, B. Schweizerische Kryptogamen.

Westendorp, G. D., \& Wallays, A. C. F. Herbier Cryptogamique Belge. Zahlbruckner, A. Kryptogamiae Exsiccatae, editae a Museo Palatino Vindobonensi (Fungi by Keissler, C.).

Zopf, W., \& Sydow, P. Mycotheca Marchica. 


\section{EXPLANATION OF PLATES 6-I7}

Unless otherwise indicated all figures are drawn with the following magnifications: perithecia $\times 47$, lateral and terminal hairs $\times$ I 80 , asci $\times 390$, spores $\times 390$.

\section{Plate 6}

\section{Chaetomium elatum Kunze \& Schmidt}

FIG. I. Mature perithecium.

FIG. 2. Lateral hair.

FIG. 3. Terminal hair.

Fig. 4. Ascus.

FIG. 5. Spores. (a) Young spores with oil globules; (b) mature spores seen in face view; $(c)$ mature spore seen edgewise.

\section{Chaetomium trigonosporum (Marchal) Chivers}

FIG. 6. Mature perithecium showing the relative size of the spore mass, $\times 25$.

FIG. 7. Mature perithecium.

FIG. 8. Lateral hair.

FIG. 9. Terminal hair.

FIG. I0. Asci showing variation in shape.

FIG. II. Spores. (a) Young spores with oil globules; $(b)$ mature spore seen in face view; $(c)$ mature spores seen edgewise.

\section{Plate 7}

\section{Chaetomium indicum Corda}

FIG. I. Mature perithecium.

FIG. 2. Terminal hair showing the characteristic dichotomy and reflexed branches.

FIG. 3. Distal portion of a terminal hair showing the encrustation of calcium oxalate.

FIG. 4. Terminal hair of a different character showing dichotomy and narrow acute angles.

FIG. 5. Distal portion of the same hair at a much older stage when its surface has become encrusted with calcium oxalate.

FIG. 6. Lateral hair.

FIG. 7. Ascus.

FIG. 8. Spores. (a) Young spores with oil globules; (b) mature spores seen in face view; $(c)$ mature spore seen edgewise.

\section{Chaetomium funicolum Cooke}

FIG. 9. Mature perithecium.

FIG. Io. Mature perithecium with slightly greater magnification, showing a variation in which the terminal hairs do not form a dense mass.

FIG. II. Lateral hair.

FIGs. I2, I3. Terminal hairs showing dichotomy.

FIGS. I4, I5. Distal portion of terminal hairs showing the encrustation of calcium oxalate.

FIGs. I6, I7. Asci.

FIGs. I8, I9. Spores. (a) Young spores with oil globules; (b) mature spores seen in face view; $(c)$ seen edgewise.

Note.-It at first seemed to the writer that the form represented by figure Io could well be considered a variety of $\mathrm{Ch}$. funicolum, but it has since been found that the variation is not constant. 


\section{Plate 8 \\ Chaetomium circinatum Chivers}

FIG. I. Mature perithecium.

FIG. 2. Terminal hair.

FIG. 3. Terminal hair showing an extreme case of circinate coiling.

FIG. 4. Ascus.

FIG. 5. Spores. (a) Young spore with oil globules; (b) mature spore; (c) mature spore showing the characteristic furrow caused by the collapse of the spore wall.

\section{Chaetomium murorum Corda}

FIG. 6. Mature perithecium.

FIG. 7. Terminal hair.

FIGs. 8, 9. Asci showing their varying shape.

FIG. Io. Spores. (a) Young spores with oil globules; (b) mature spores; (c) mature spore showing the characteristic furrow caused by the collapse of the spore wall.

Plate 9

\section{Chaetomium simile Massee \& Salmon}

FIG. I. Mature perithecium.

FIG. 2. Terminal hair.

FIG. 3. Ascus, copied from the original drawing by Massee and Salmon, $\times 400$ and reduced by one half.

FIG. 4. Spores. (a) Young spores with oil globules; (b) mature spores seen in face view; (c) mature spore seen edgewise.

\section{Chaetomium CRispatum Fuckel}

FIG. 5. Mature perithecium.

FIGS. 6, 7. Terminal hairs showing the variation in the manner of coiling.

FIG. 8. Ascus.

FIG. 9. Spores. (a) Young spores with oil globules; (b) mature spores seen in face view; $(c)$ mature spore seen edgewise.

\section{Chaetomium contortum Peck}

FIG. Io. Mature perithecium.

FIG. II. Terminal hair.

FIG. I2. Spores. (a) Young spores with oil globules; (b) and (c) mature spores.

Chaetomium tortile Bainier

FIG. I3. Mature perithecium.

FIG. I4. Terminal hair.

FIG. I5. Terminal hair, distal portion showing the variation in the manner of coiling.

FIG. I6. Ascus.

FIG. I7. Spores. (a) Mature spores seen in face view; $(b)$ seen edgewise.

\section{Plate io}

\section{Chaetomium Spinosum Chivers}

FIG. I. Mature perithecium.

FIG. 2. Mature perithecium showing the steeple-like cirrhus of spores. 
FIG. 3. Terminal hair with branches.

FIG. 4. Distal portion of a branch of the terminal hair.

Figs. 5, 6. Asci in different stages of development.

FIG. 7. Spores. (a) Young spores with oil globules; $(b)$ mature spore.

\section{Chaetomium ampullare Chivers}

FIG. 8. Mature perithecium showing the relative size of the spore mass, $\times 25$.

FIG. 9. Mature perithecium.

FIG. Io. Terminal hair.

FIG. II. Ascus.

FIG. I2. Spores. (a) Young spores with oil globules; (b) mature spores seen in face view; (c) seen edgewise.

\section{Chaetomium globosum Kunze}

FIG. I3. A germinating spore showing the cast-off exospore and the persistent endospore, $\times 390$.

FIG. I4. A slightly later stage, showing the origin of the mycelial branches from the endospore.

FIG. I5. A germinating spore in which the endospore does not appear as a persistent vesicle.

FIG. I6. A diagrammatic drawing of the mycelium, showing its radial growth.

\section{Plate II}

\section{Chaetomium trilaterale Chivers}

FIG. I. Mature perithecium.

FIG. 2. Mature perithecium under greater magnification, $\times 94$.

FIG. 3. Lateral hair.

FIG. 4. Terminal hair.

FIG. 5. Ascus.

FIG. 6. Spores. (a) Young spores with oil globules; (b) mature spores seen in face view; $(c)$ mature spore seen edgewise.

\section{Chaetomium FUSiforme Chivers}

FIG. 7. Mature perithecium.

FIG. 8. Mature perithecium under greater magnification, $\times 94$.

FIG. 9. Terminal hair.

FIG. IO. Ascus.

FIG. II. Spores. (a) Mature spores seen in face view; $(b)$ seen edgewise.

\section{Chaetomium aureum Chivers}

FIG. I2. Mature perithecium.

FIG. I3. Mature perithecium under greater magnification, $\times 94$.

FIG. I4. Mature perithecium showing the relative size and characteristic curvature of the spore cirrhus, $\times 25$.

FIG. I5. Terminal hair.

FIG. I6. Ascus.

FIG. I7. Spores. (a) Young spores with oil globules; (b) mature spores seen in face view; (c) mature spore seen edgewise. 


\section{Chaetomium sphaerale Chivers}

FIG. I8. Mature perithecium.

FIG. I9. Mature perithecium showing the relative size of the spore mass, $\times 20$.

FIG. 20. Lateral hairs. (a) Short and sinuous; (b) somewhat longer, nearly straight and unbranched; $(c)$ still longer and branched.

FIG. 21. Terminal hair.

FIG. 22. Ascus.

FIG. 23. Spores. (a) Young spores with oil globules; $(b)$ mature spores seen in face view; $(c)$ seen edgewise.

Plate I 2

Chaetomium aterrimum Ellis \& Everhart

FIG. I. Mature perithecium.

FIG. 2. Lateral hair.

FIG. 3. Terminal hair.

FIG. 4. Spores. (a) Mature spores seen in face view; $(b)$ mature spore seen edgewise.

\section{Chaetomium SPirale Zopf}

FIG. 5. Mature perithecium.

FIG. 6. Terminal hair.

FIG. 7. Lateral hair.

FIG. 8. Spores. (a) Mature spores seen in face view; $(b)$ mature spore seen edgewise.

\section{Plate 13}

\section{Chaetomium bostrychodes Zopf}

FIGS. I, 2, 3. Mature perithecia showing the characteristic variation.

FIG. 4. Terminal hair, branched and irregularly convolute.

FIG. 5. Terminal hair, regularly spirally coiled.

FIG. 6. Terminal hair, branched and regularly spirally coiled with ten coils.

Fig. 7. Portion of a terminal hair showing the encrustation of calcium oxalate.

Figs. 8, 9, I0. Asci, showing different stages of development.

FIG. II. Spores. (a) Mature spores seen in face view showing a characteristic refractive area at each end; $(b)$ mature spores seen edgewise.

\section{Chaetomium subspirale Chivers}

FIG. I2. Mature perithecium.

FIG. 13. Mature perithecium showing the relative size of the spore mass, $X{ }_{5}$.

FIG. I4. Lateral hair.

FIG. I5. Terminal hair.

Fig. I6. Ascus.

FIG. I7. Spores. (a) Young spores with oil globules; (b) mature spores seen in face view; (c) seen edgewise.

\section{Chaetomium caprinum Bainier}

FIG. I8. Mature perithecium.

FIGS. 19, 20. Terminal hairs with branches.

FIG. 2I. Ascus.

FIG. 22. Spores. (a) Young spore with oil globules; $(b)$ mature spores seen in face view; $(c)$ mature spore seen edgewise. 


\section{Plate I4}

\section{Chaetomium Quadrangulatum Chivers}

FIG. I. Mature perithecium with the greater portion of the spore mass removed. FIG. 2. Mature perithecium.

FIG. 3. Mature perithecium showing the relative size of the spore mass, $X$ I 5 .

FIG. 4. A spirally coiled terminal hair.

FIG. 5. An irregularly convolute terminal hair with branches.

FIG. 6. Ascus seen in face view.

FIG. 7. The same ascus seen edgewise.

FIG. 8. Spores. (a) Mature spores seen in face view; (b) seen edgewise; c.) grouped in a characteristic manner.

\section{Chaetomium convolutum Chivers}

FIG. 9. Mature perithecium.

FIG. Io. Terminal hair.

Fig. II. Ascus.

FIG. I2. Spores. (a) Young spore with oil globules; $(b)$ mature spore seen in face view; $(c)$ mature spores seen edgewise.

\section{Plate I5}

\section{Cha etomium cochliodes Palliser}

FIG. I. Mature perithecium.

FIG. 2. Mature perithecium, showing the relative size of the spore mass, $X$ I5.

FIG. 3. Lateral hair.

FIG. 4. A slender, spirally coiled terminal hair.

FIG. 5. A slender, sinuous terminal hair with branches.

FIG. 6. A stout, spirally coiled terminal hair.

Fig. 7. Ascus.

FIG. 8. Spores. (a) Young spores with oil globules; (b) mature spore seen in face view; (c) seen edgewise.

\section{Chaetomium globosum Kunze}

FIG. 9. Mature perithecium.

FIG. IO. Mature perithecium showing the relative size of the spore mass.

FIG. II. Terminal hair.

Fig. I2. Ascus.

FIG. I3. Young spores with oil globules.

FIG. I4. Mature spores.

Plate i6

\section{Chaetomium torulosum Bainier}

FIG. I. Mature perithecium.

FIG. 2. Lateral hairs.

FIG. 3. Terminal hair with branches.

FIG. 4. Ascus.

FIG. 5. Spores. (a) Large spore when young with oil globules; (b) large mature spores seen in face view; $(c)$ small spores when young with oil globules; $(d)$ small mature spores seen in face view; $(e)$ spores seen edgewise. 


\section{Chaetomium angustum Chivers}

FIG. 6. Mature perithecium.

FIG. 7. A straight terminal hair. For convenience the hair is figured in two parts.

FIG. 8. A slender terminal hair spirally coiled near its tip.

FIG. 9. A stout terminal hair spirally coiled near its tip.

FIG. I0. An irregularly convolute terminal hair with a branch. For convenience the hair is figured in two parts.

FIG. II. Ascus.

FIG. I2. Spores. (a) Young spores with oil globules; $(b)$ and $(c)$ mature spores seen in face view; $(d)$ seen edgewise.

\section{Plate 7}

\section{Ascotricha ChaRTARUm Berkeley}

FIG. I. Mature perithecium.

FIG. 2. A perithecium developing from the rope-like mycelial strand, $X{ }_{5}$.

FIG. 3. Terminal hair, showing its ampullate swellings.

FIG. 4. Terminal hair of slightly different character.

FIG. 5. Conidiophore with its clusters of conidia, $X \pm 80$.

FIG. 6. A portion of a conidiophore under greater magnification, $\times 390$.

FIG. 7. A small portion of a conidiophore with four conidia, $\times 390$.

FIG. 8. Conidia, $\times 390$.

FIG. 9. Conidiophores developing from the rope-like mycelial strand, $\times 25$.

FIG. ro. A young ascus.

FIG. II. A mature ascus.

FIG. I2. Spores. (a) Seen in face view; $(b)$ seen edgewise showing their girdle.

Ascotricha pusilla (Ellis \& Everhart) Chivers

FIG. I3. Mature perithecium.

FIGS. 14, 15. Terminal hairs showing their ampullate swellings.

FIG. I6. Conidiophore with its cluster of conidia, $X 180$.

FIG. I7. Conidiophore of a slightly different character, $X$ r 80 .

FIG. I8. A portion of a conidiophore under greater magnification, $\times 780$.

FIG. 19. Conidia, $\times 390$.

FIG. 20. Ascus.

FIG. 2I. Spores. $(a)$ and $(b)$ seen in face view; $(c)$ edgewise. 


\section{INDEX}

New names, the final members of new combinations, and the numbers of the pages on which the descriptions are to be found are in bold face type.

Acanthostigma Chaetomium, 210 nivale, 2 I 3

Anixia perichaenoides, 214

Ascotricha chartarum, I62, I98, 216, 218 , $221,222,223$

pusilla, 162, $219,220,224$

Zopfii, 222

Asteroma Alchemillae, 2 I I

Bommerella trigonospora, I6ó

Caelospheria exilis, 2 ro

Ceuthospora phaeocomes, 2 I 2

Chaetomella atra, 2 I 4

Cavallii, I76, I 77

raripila, 213

Chaetomidium fimeti, I6r, I86, 194, 199, 2I3, 2 I 5

Chaetomium Abietinum, 2 I6

affine, I90, 193

Alchemillae, 2 Io

amphitrichum, 190, 193

ampullare, 187,207

angustum, 206

arachnoides, 217

Araliae, 190, I93

aterrimum, I6 I, 200

atrum, I $80,182, \mathrm{I} 83, \mathrm{I} 85, \mathrm{I} 86,2 \mathrm{I} 5$

atrum, var. distinctum, I80, I82, I 85

atrum, var. Therryana, I80, I82, I86, 215

aureum, I74, I75, I76

Bartholomaei, I 76, I 77

Berkeleyi, 222, 223

bostrychodes, I6I, I62, 200, 20I, 202, 204

Braunii, 2I2, 2 I3

Bromelliae, 2 I 7

calvescens, 2I4, 215

caninum, I6I, 20I, 202

caprinum, I62, 203, 209

chartarum, I57, I86, I90, I9I, I93, I96, I98, I99, 205, 222, 223

ciliatum, 2 I 2, 2 I3

circinans, 2 I0, 2 I I

circinatum, 168

coccodes, 2 IO, 2 I I

cochliodes, I6I, I99, 204, 205, 206

comatum, I80, I 82, I 83, I 84, I86, 209

comatum, var. helicotrichum, I66, I67, I 80

comatum, var. ligni, I 80, I 82, I 85

comosum, I62

concinatum, 2 I 2,2 I 3

contortum, I6I, I62, I69, I70, I72
Chaetomium convolutum, $\mathbf{1 7 3}$

crispatum, I60, I6I, I62, I69, I70,

I 7 I, I 72, I 85, I96, 2 I I

Cumingii, 2 I 2

cuniculorum, I6I, 188

cymatotrichum, 190, 196

delicatulum, 222, 223

depressum, 2 I0, 2 I I

discolor, 208

Douglasii, 198, 208

Elasticae, 190, 197

elatum, I59, I68, I 78, I80, I82, I83, I 84, I 85, I86, I98, I99, 209

Ellisianum, I62, 220, 22I

epiphyllum, 210, 2 I I

exile, 215

Fieberi, I81, I84, 190, 192, I93, 194, I96, I98, 199

Fieberi, var. chartarum, I80, I82, $185,186,192,198$

Fieberi, var. chlorina, 190, 192, 194

Fieberi, var. macropoda, 198, 209

Fieberi subspecies Saccardianum, I90, 196

fimeti, 2 I3

fimisedum, 2 I 4

flexuosum, I6I, 204, 205

formosum, 162, 201, 202

formosum, var. neglectum, I62, $20 \mathrm{I}$, $20 I$

formosum, var. ovatum, I62, 20I, 202

funicolum, I60, I76, I77, I78, I80, I 86

fusiforme, I 74, I 75, I 76

gelatinosum, 2 Io

glabrescens, I 8 I, I 86

glabrum, Bain., I62, I69, I 70

glabrum B. \& Br., 2 I 4

globosum, I59, I6I, I62, I 82, I90, I92, I93, I94, I95, I96, I97, I98, I99, 205, 206, 207, 208, 209

globosum, var. chartarum, 2 I 5

graminicolum, I8I, I 82, I 84

graminis, $I 8 I, I 82, I 84$

griseum, 167

hispidum, 2 I 2

humanum, 208

importatum, 2 I6

indicum, I60, I6r, I62, I78, I79, I 80 . I 86

Kunzeanum, I6r, I67, I86, I89, I90, I92, I93, I97, I9S, I99

Kunzeanum, var. chlorina, I90 
Chaetomium Kunzeanum, var. fimicolum, Chaetomium spirochaete, I6 I, I99, 200 I96

laeliicola, 216, 2 I 7

lageniforme, I8I, I82, I84

lanatum, 208

lanosum, I62, I86, I90, I92, I94, I99, 209

Libertii, I 81 , I 82, I 85

macrosporum, I90, I95

marchicum, 2 I6

megalocarpum I62, I90, 198

melioloides, I62, I 78, I 79

microsporum, 208

Montagnei, 2 I 8

Montemartinii, 215

murorum, I60, I6I, I66, I67, I68, I82, I86, I95, I96, I99, 2 I3, 2 I 7 , 218

nivale, $2 \mathrm{I} 3$

olivaceum, I62, I 86, I90, I95, I99

olivaceum, var. chartarum, E. \& E., I9I, 192

olivaceum, f. chartarum Roum., I9I oospora, I9I, I97

orientale, I9I, I94

oxysporium, 2 ro, 2 I I

pallidum, 215

pannosum, I6I, I8I, I82, I84, I85, I 86,2 I 3

papillosum, 2 I 7

paucisetum, 2 I 4

Polypori, 2 I 4

Potentillae, 2 I o, 2 I I

pusillum E. \& E., I 57, 218, 219, 220, 22 I

pusillum Fries, 2 I0

quadrangulatum, I66, 202

raripilum, 2 I3

rigidulum, 162

rostratum, 204, 209

rufulum, 2 I 4

setosum Bain., I62, I9I, I98

setosum E. \& E., I 76, I 77

setosum Wint., I62, I 78, I 79, I 80

signatum, 2 I 2,213

simile, I6I, I69, I 70, I 72

sphaerale, 189

sphaerospermum, I62, 216, 222 , 223

spinosum, 187

spirale, I6I, I99, 200

spirilliferum, I62, I9I, 198

stercoreum, 208

Streptothrix, I 7 I

strigosum, 2 10, 2 I 2

subnudum, 2 I 8

subspirale, I 73

tomentosum, 2I 2, 2 I3

tortile, I62, I69, I 70, I72

torulosum, I62, 207

trigonosporum, I66, 203

trilaterale, I 74, I 75

Typhae, 2 I 2

Typhinum, 2 I 2

undulatum, I62, I9I, I98

varium, 208

velutinum, I8I, I 85

viride, 2 I 2

Zopfii, 222, 223

Coleroa Alchemillae, 2 I I

Chaetomium, 2 I I

Potentillae, 2 I 2

Conoplea atra, I8I, I83

Dicyma ampullifera, 222

Dinemasporium ciliatum, 2 I 3

Dothidea Alchemillae, 2 I I

ceramioides, 2 I I

Chaetomium, 2 I I

Potentillae, 2 I 2

Fusarium Chaetomium, 2 II

Myxotrichum chartarum, I 83

Niesslia Chaetomium, 2 Io

exilis, 2 Io

pusilla, 2 Io

Nitschkia exilis, 2 Io

Oospora crustacea, 197

Orbicula perichaenoides, 2 I 4

Peronospora infestans, I $7 \mathrm{I}$

Peziza aterrima, 2 I 0

Sphaeria Chaetomium, 210

Sphaeria comata, I8I, I 83, 208

Sphaeria crispata, I 7 I

Sphaeria exilis, 2 I0

Sphaeria exosporioides, 2 Io

Sphaeroderma marchicum, 2 I6

Stachybotrys lobulata

Stigmatea Alchemillae, 2 I I

Chaetomium, 2 I I

Potentillae, 2 I 2

Venturia Alchemillae, 2 I I

Chaetomium, 2 Io

Kunzei, 2 II

Potentillae, 2 I 2 


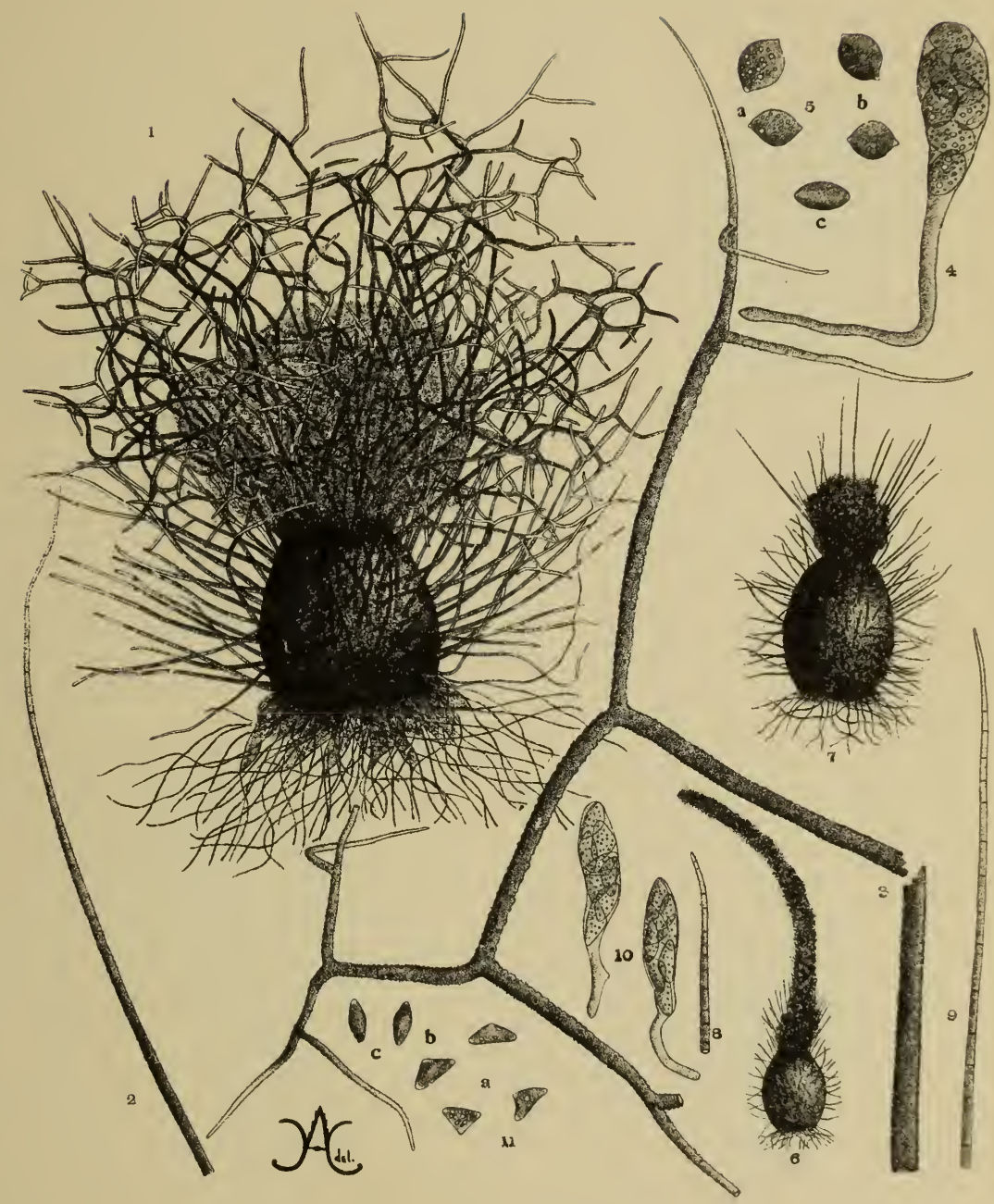





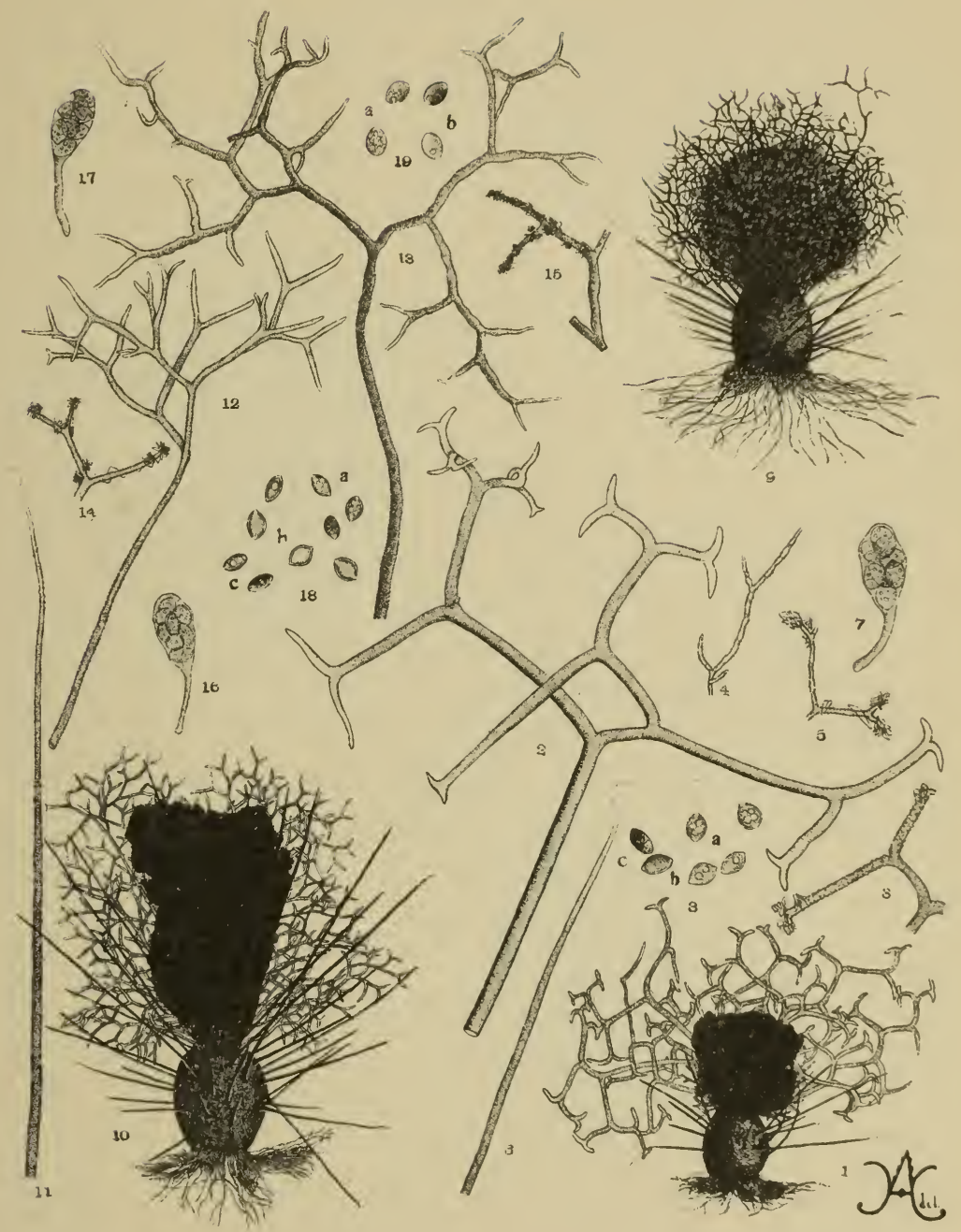





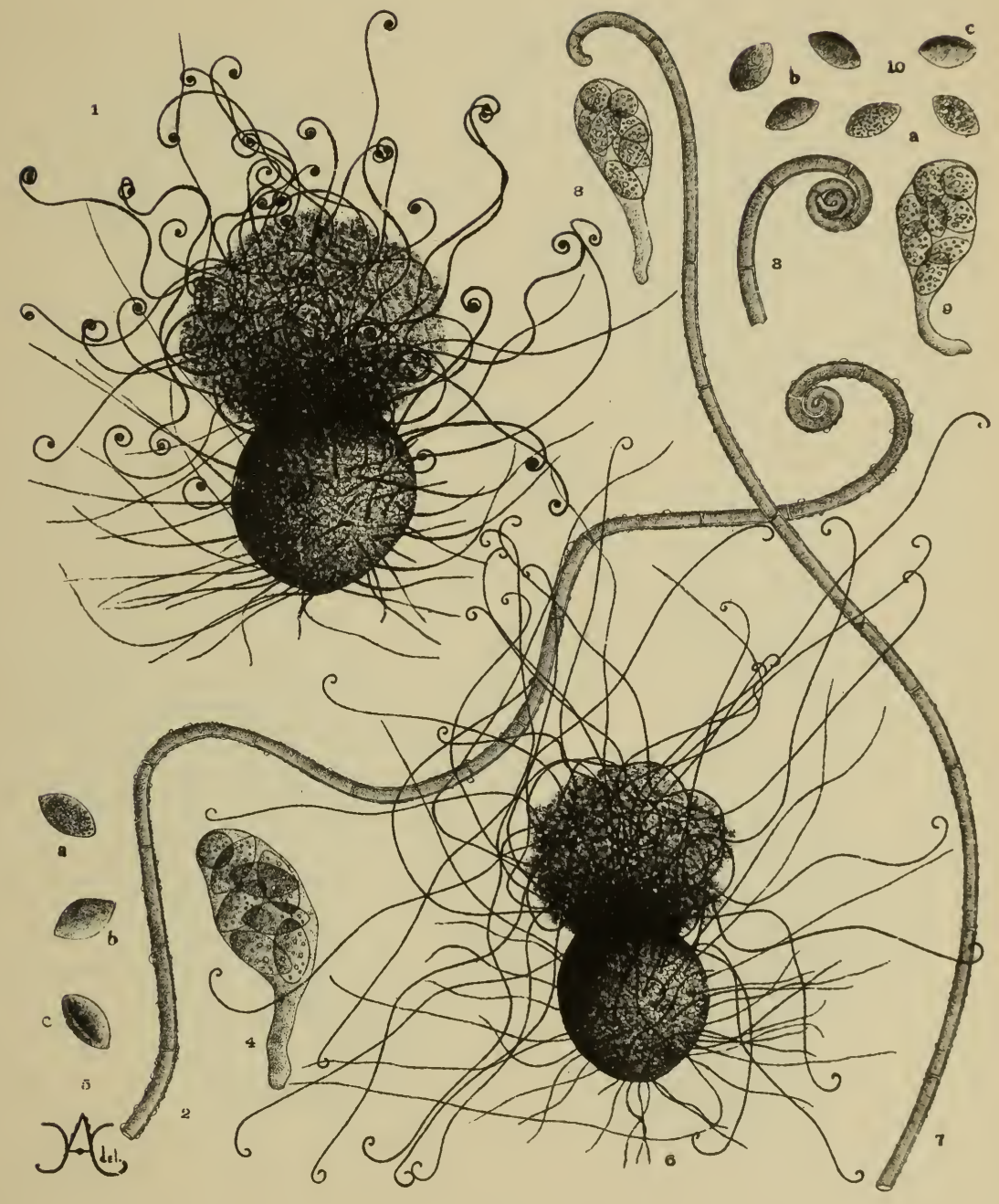





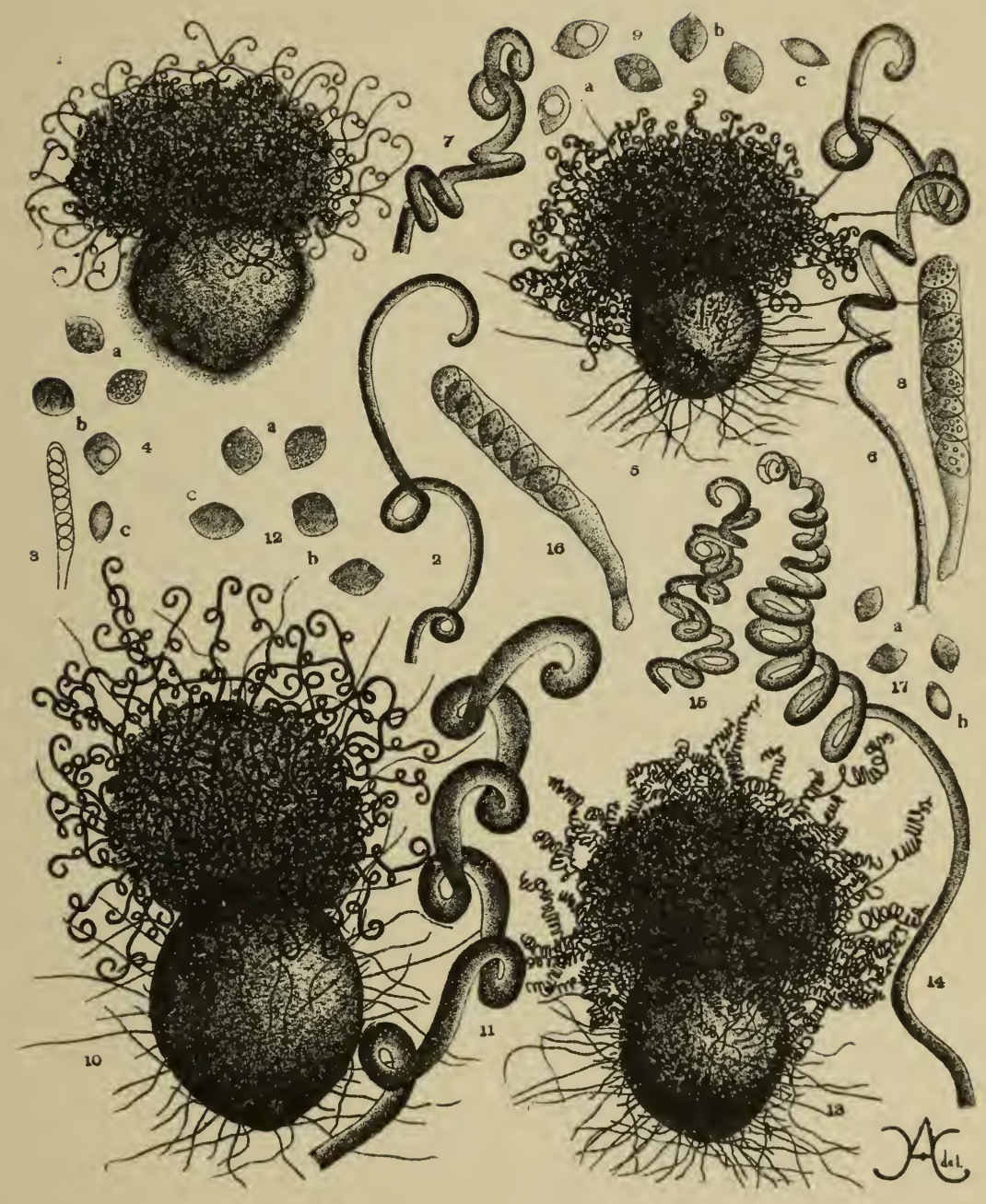

I-4. CIIAETOMIUM SIMILE MASSEE \& SIIMON

5-9. CHIETOMILM CRISPATUM FUCKEL

IO-I 2. CIALETOMITM CONTOR'IUM PECK

13-I7. CHAETOMIUM TORTILE BNINIE 



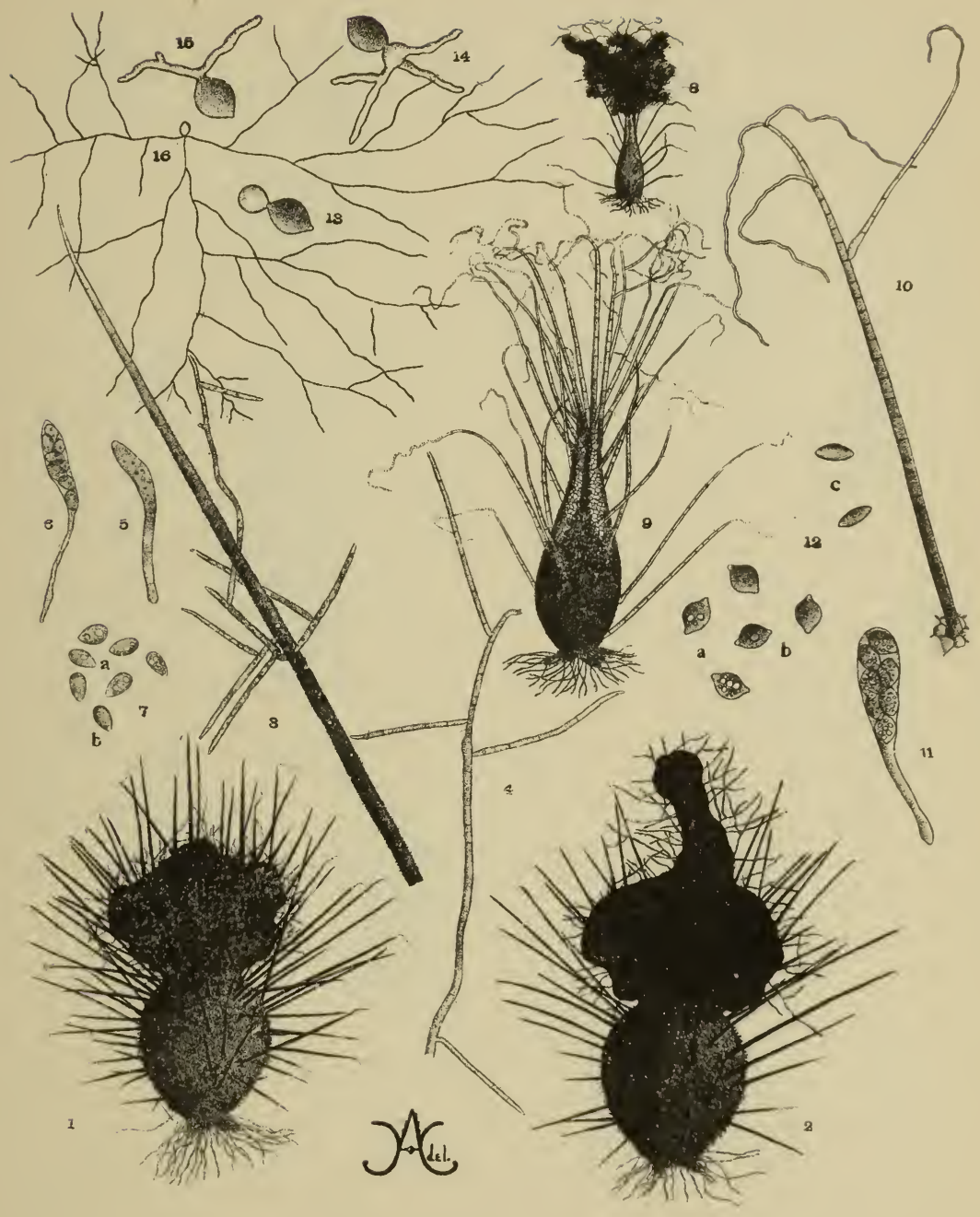

1-7. CIIAETOMIUM SIINOSUM CIINERS

S-12. CIIAETOMIUM AMPLLLARE CIITERS 13-16. CIIAE'TOMILM GL,OBOSUM KUNE 



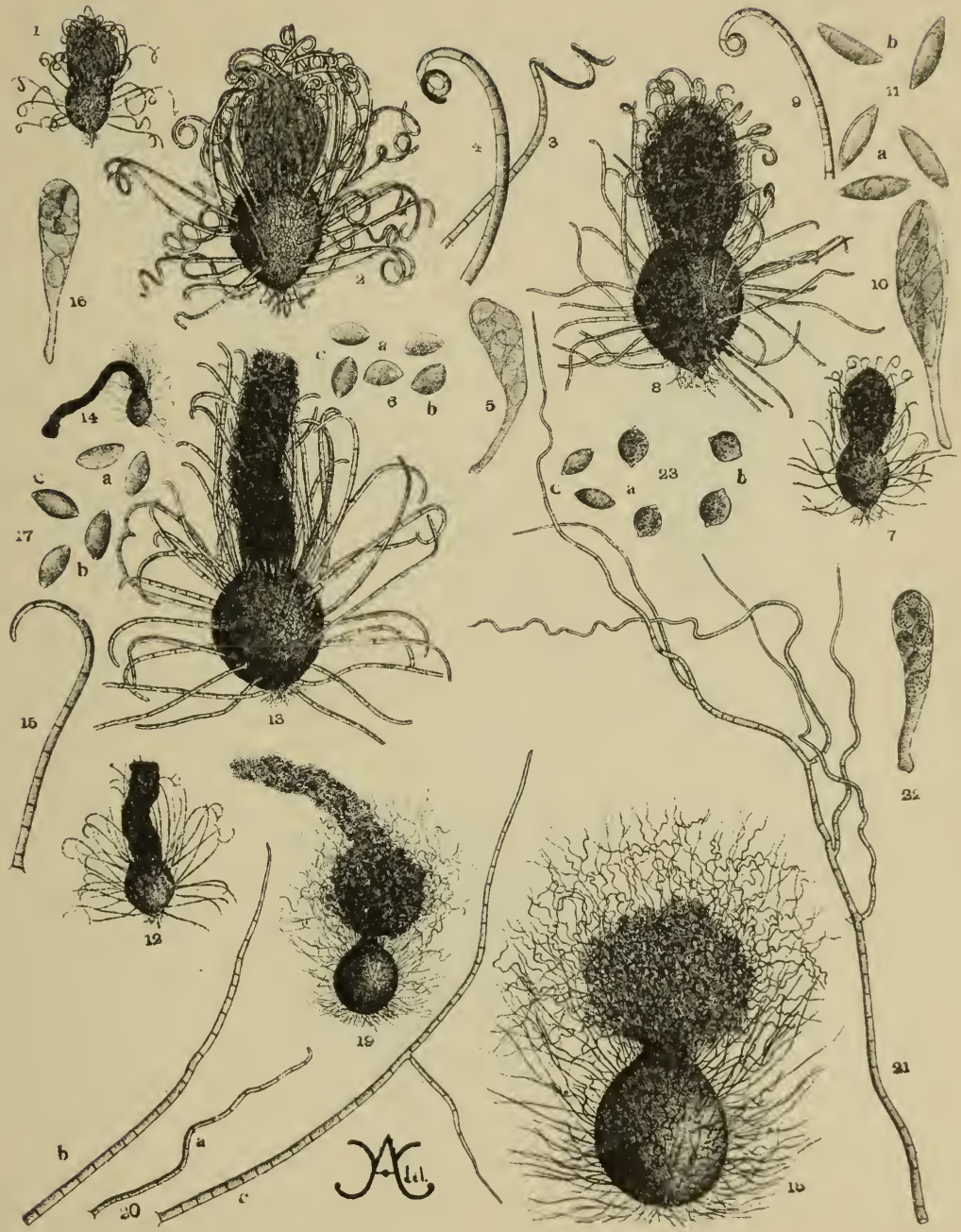





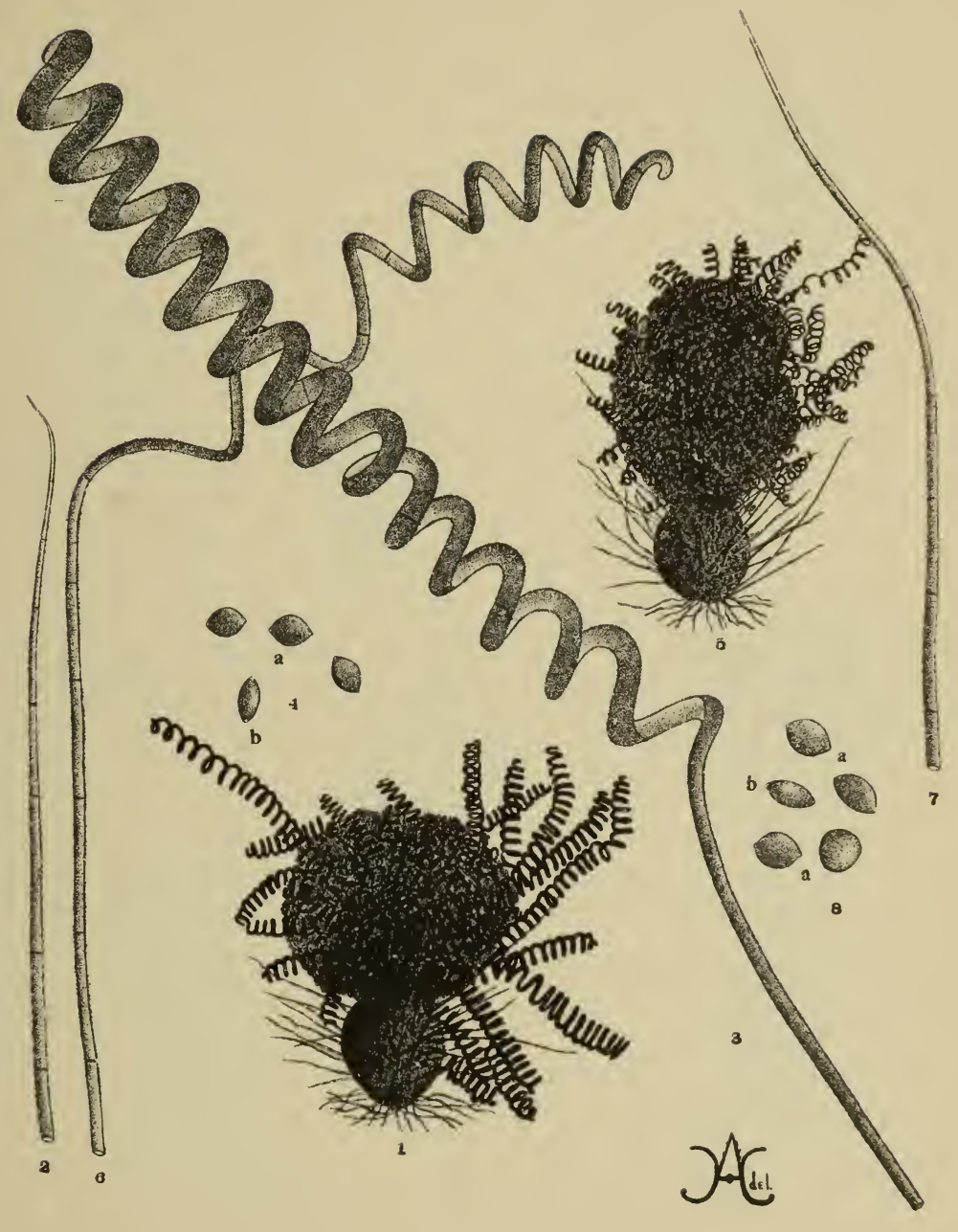





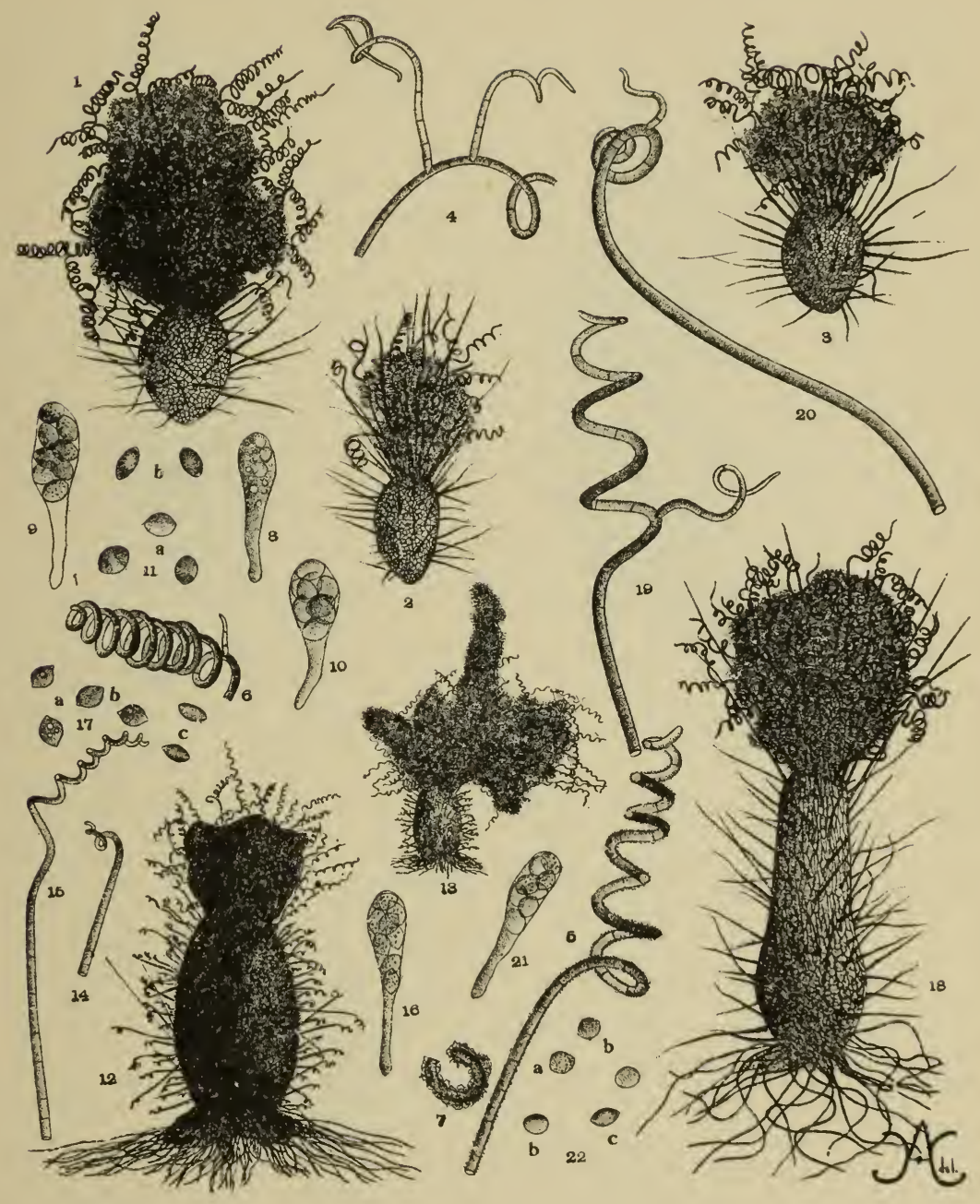





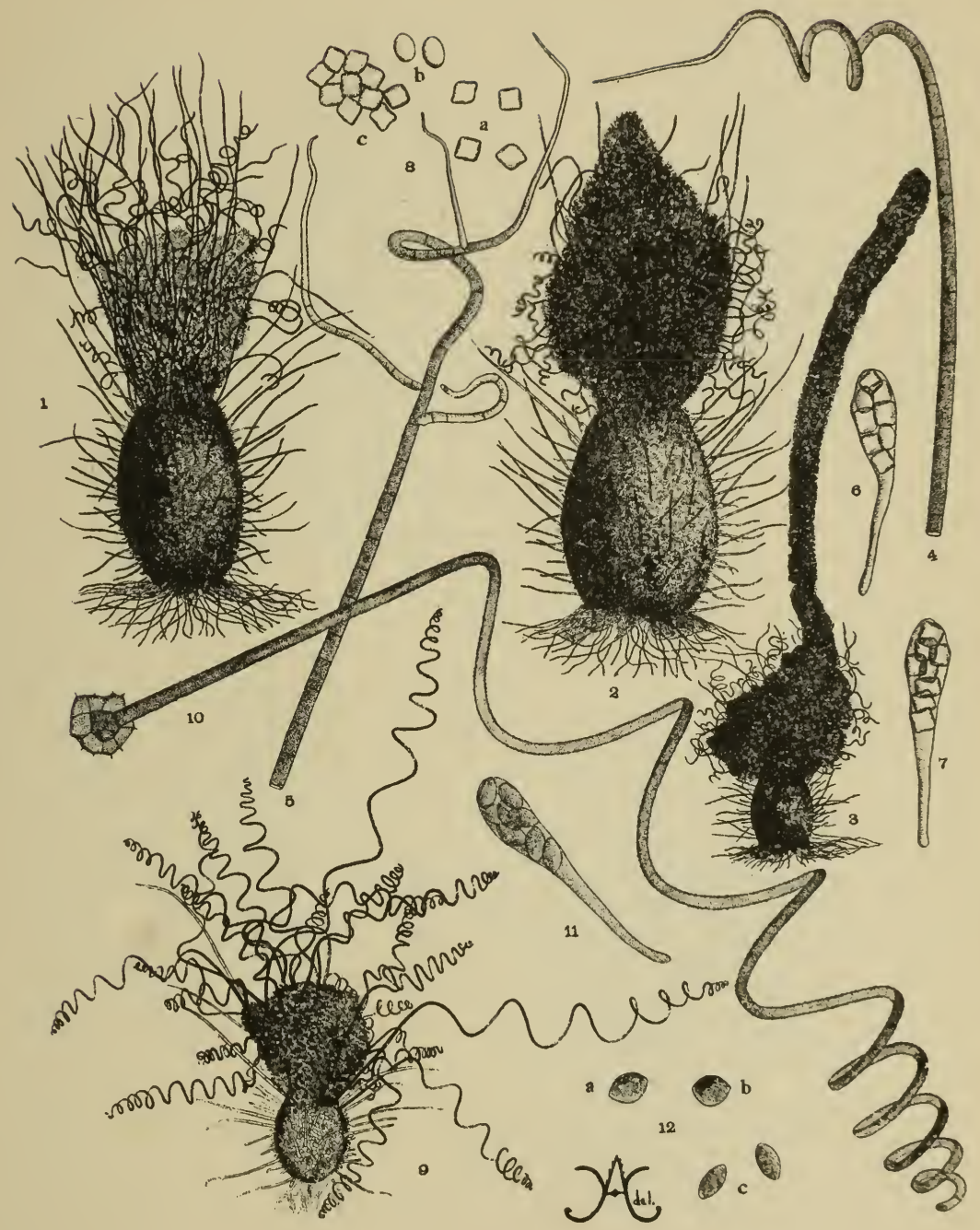





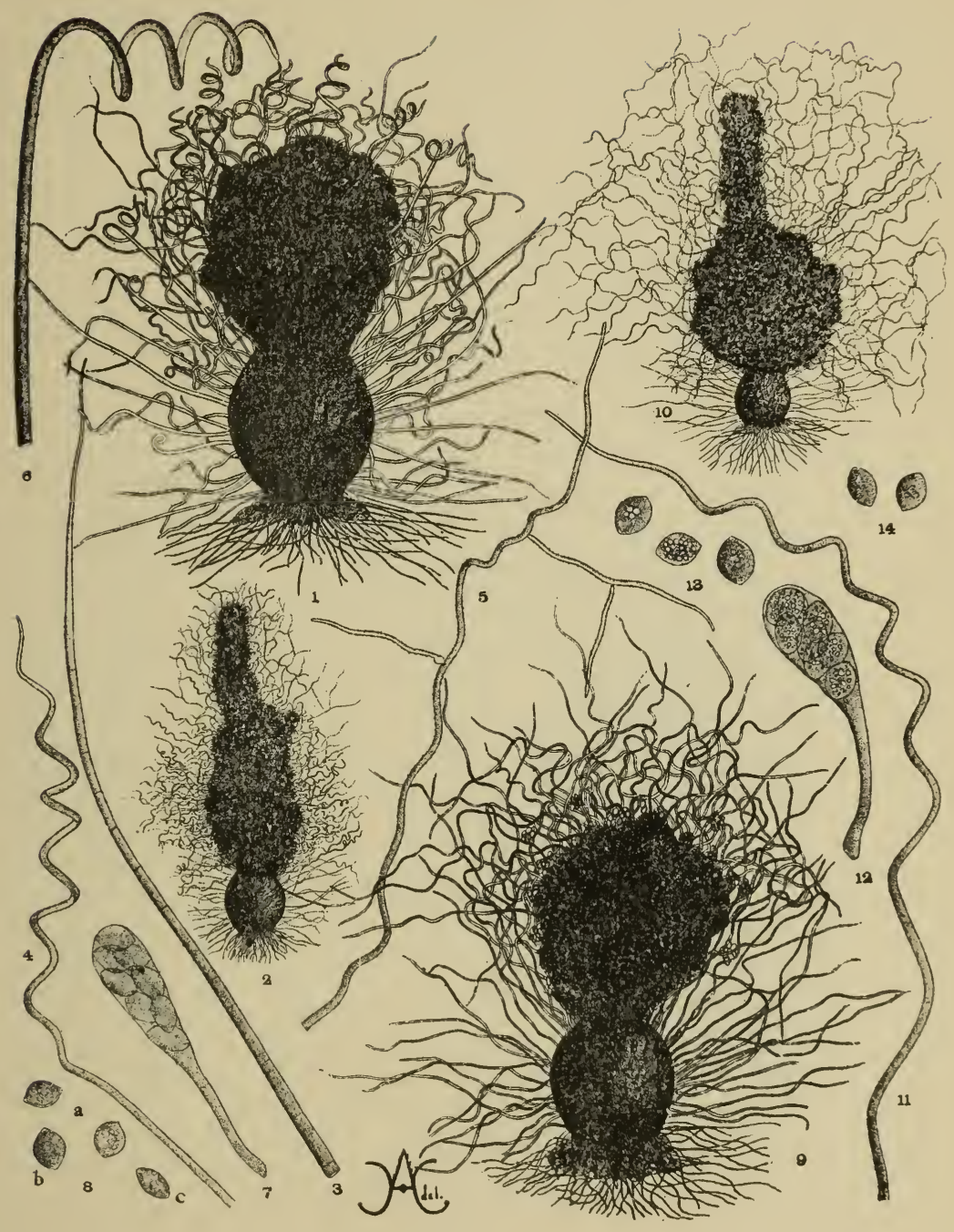





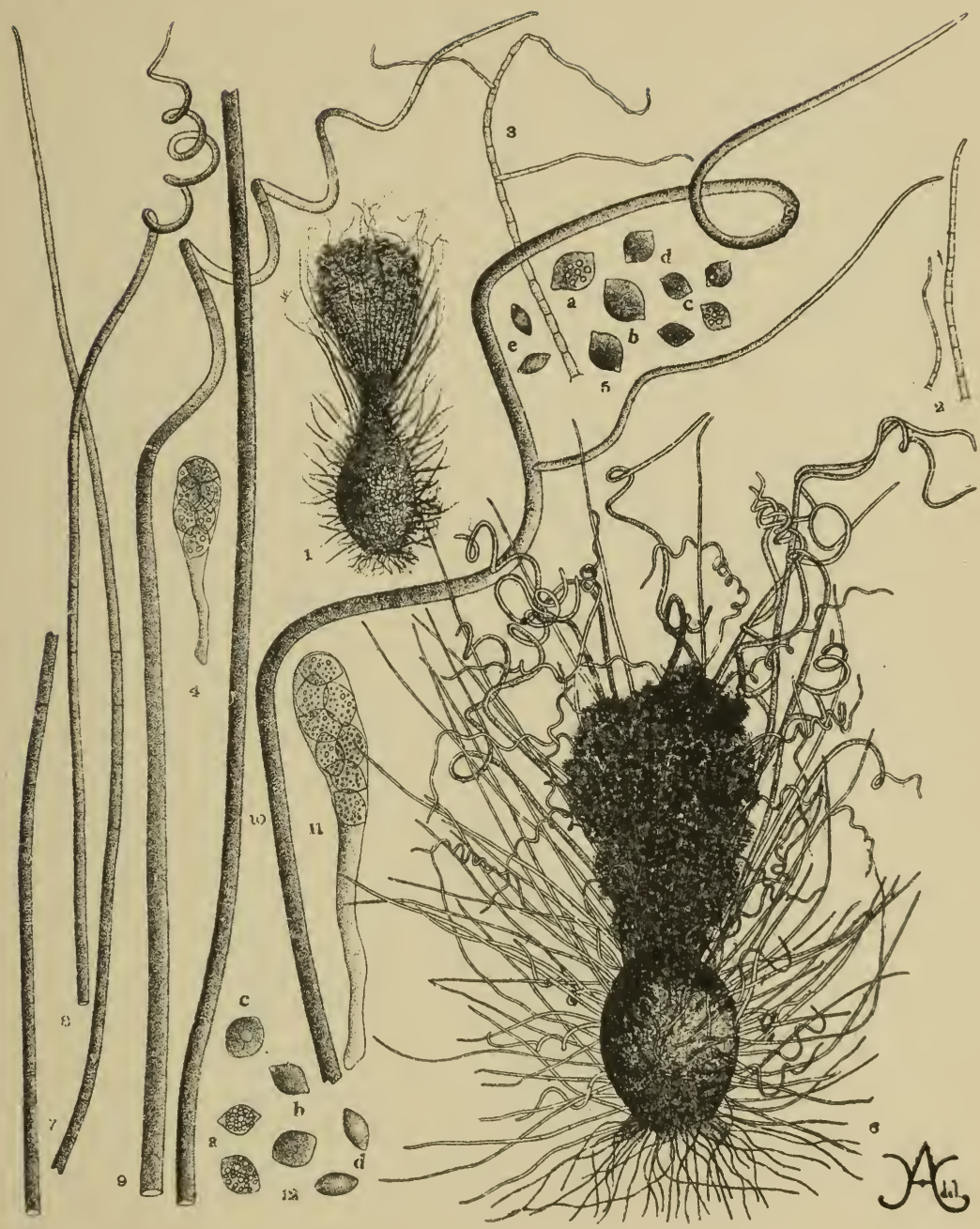





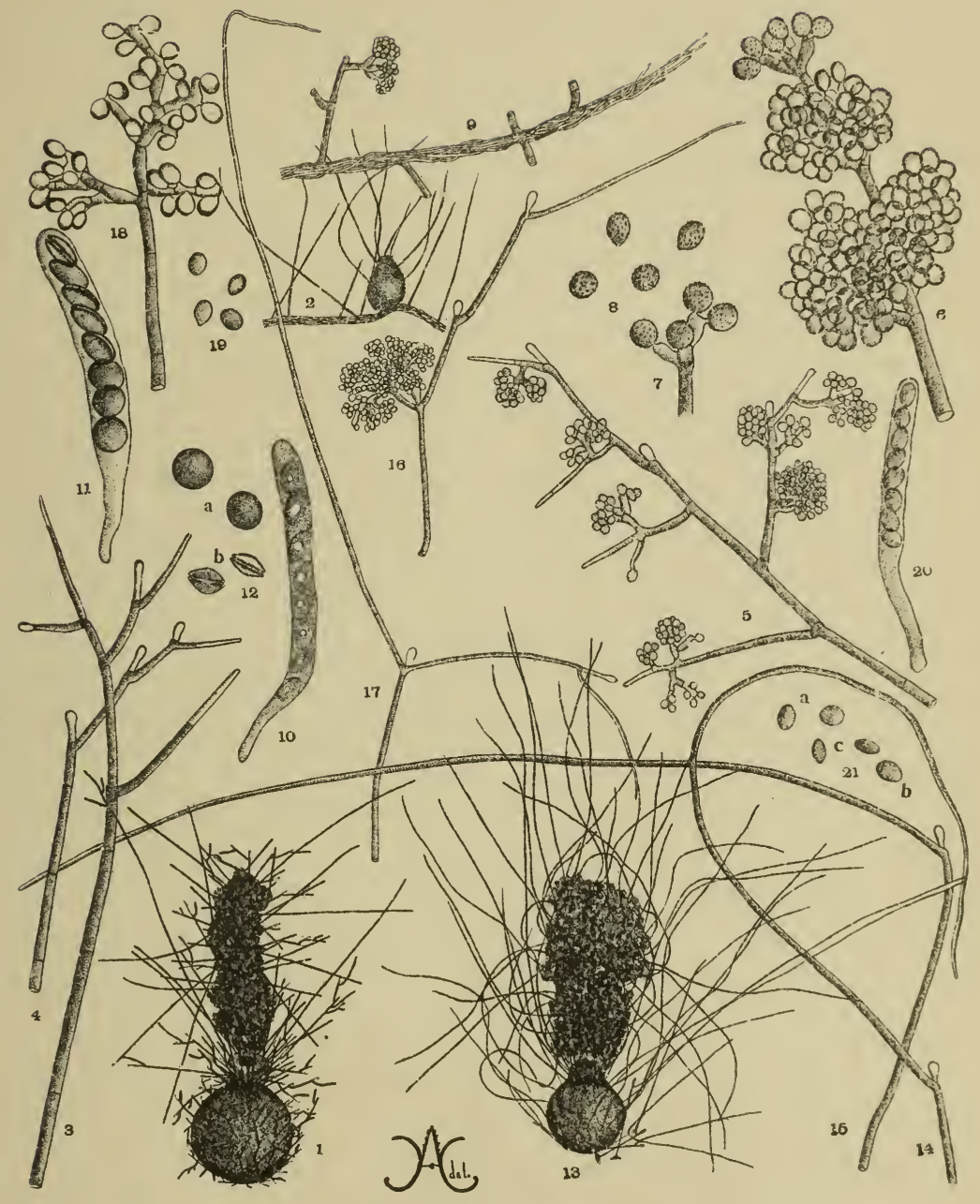




